\title{
Early Miocene ants (Hymenoptera, Formicidae) from Radoboj, Croatia
}

\author{
Gennady M. Dlussky and Tatyana S. Putyatina
}

With 18 figures and 2 tables

\begin{abstract}
The ant assemblage of Radoboj (Croatia) described by Heer $(1849,1867)$ is considered the richest known Miocene assemblage of Europe. However, HeER's data can no longer be used for analysis of the palaeontological history of ants, because they are strongly outdated and require a revision. Such a revision was the purpose of our study. We found in collections of three museums of Austria (Universalmuseum Joanneum in Graz, Geologische Bundesanstalt, and Naturhistoricshes Museum in Wien) a total of 537 compression fossils of ants from Radoboj, 459 of which were identified earlier by HeER. We designated the holotypes, lectotypes and neotypes for 54 of the 62 species described by HeER, and subsequently compared the other specimens to these types. As a result, we have identified 350 specimens to subfamily and 309 specimens to species. We re-described 23 species originally described by HeER $(1849,1867)$ and two species described by MAYR (1867). One genus and eight species are described as new; 27 species and varieties described by HeER are synonymized. The taxonomic placement of eight species described by HeER remains unclear. As a result of our revision, the known assemblage of Radoboj includes 33 species of 15 genera and five subfamilies. The assemblage of Radoboj is especially similar at the subfamily level to the assemblage of Bembridge, UK (Late Eocene) and Stavropol, RF (Middle Miocene).
\end{abstract}

Key words: Formicidae, revision and new taxa, Early Miocene, Radoboj, Croatia.

\section{Introduction}

The first substantial study of fossil ants was the monograph on insects from the Miocene deposits of Oeningen (Germany) and Radoboj (Croatia) by HeER (1849). Before this monograph, various authors described in 1822-1831 a total of 11 ant species. These were from Baltic amber, and are currently treated as Formicidae incertae sedis (DLUSSKY 2008a), or are from deposits (perhaps Miocene) near Bonn (Germany), including Formica lignitum Germar, 1837. In HeEr's monograph, 68 species and varieties of ants were described, including 40 species from Radoboj. In his later studies, HeER $(1864,1867)$ added 26 new species and varieties to this checklist (22 of them from Radoboj). Two other species were described from Radoboj by MAYR (1867). To date, a total of 64 species and varieties of fossil ants have been described from Radoboj. Beyond this deposit, a greater number of species have only been described from the Late Eocene ambers of Europe and from Miocene Dominican amber.

However, in the $19^{\text {th }}$ century it was already clear that HEER's data were in need of a serious revision. In 1867 MAYR studied a collection of ants from Radoboj that were identified by HeER and stored in the Kaiserlich-Königliche Geologische Reichsanstalt (Austria). It turned out that in many cases the same species name was attributed to members of different genera and even subfamilies. HEER (1867) commented on MAYR's article in an footnote and suggested that some labels in the collection identified by HEER were probably mixed up. Unfortunately, this suggestion cannot be verified now. Although the majority of specimens in the studied collections have old numbers drawn directly on the rock surface, HEER never indicated the numbers of specimens examined in his publications. 
Since MAYr was unable to acquire HEer's type materials for examination, he could not perform a wholesale revision, and restricted himself to identifying the ants to the genus-level. Subsequently, the generic names of ants assigned by HEER were changed in the catalogue of fossil insects prepared by HANDLIRSCH (1907), who used data for the MAYR's results. He himself did not study HEER's collection, but his interpretations were subsequently accepted by other authors (BOLTON 1995, and others).

In his monograph, HEER used a classification of ants that was already outdated by the standards of 1849 , and even more so by 1867 , after the publication of the study by MAYR (1855) laid the foundations of our modern classification. This is clear from HeER's (1849) descriptions of genera, as well as his notes surrounding the description of new taxa, in which he compared extinct species directly to extant ones. He placed all Formicinae in the genus Formica and all Myrmicinae in the genus Myrmica, although, at that time, many of the species he included in these two genera already belonged to other genera. He placed all ants from Radoboj in only four genera: Formica (waist one-segmented, forewing without a closed rm cell), Ponera (in 1867, Poneropsis; waist one-segmented, forewing with closed rm cell), Myrmica (waist two-segmented, forewing with closed mcu cell) and Attopsis (waist two-segmented, forewing without closed mcu cell). According to the modern system, HeER's "Formica" includes all Formicinae, his "Poneropsis" includes the majority of species of Poneromorpha and Dolichoderinae, and his "Myrmica" includes the majority of Myrmicinae. As for Attopsis, the establishment of this genus was based on an erroneous interpretation of imprints, as will be shown below.

After MAYR's work, no research scientists have revisited HeER's collections, although it was obvious that the material needed a revision. Such a revision was the purpose of our study. With this in mind, we examined ants from the deposits of Radoboj stored in three museums of Austria. The most valuable collection is stored in Universalmuseum Joanneum, Department for Geology \& Palaeontology (UMJG\&P). It includes 148 imprints from Radoboj, attributed here to 41 species. The 139 specimens bear original labels written by HeEr. As many as 39 specimens ( 28 species) match figures in HeER's monographs (i.e., they are doubtlessly type specimens). The last revision of the collection was performed by students (unfortunately, unqualified for this kind of work) around 1995. After the latter work, the vast majority of specimens were assigned five-digit catalogue numbers. In the text of this study we provide the numbers of specimens from this catalogue. One caveate should be noted, however. All of the specimens identified by HeER are labelled as holotypes or syntypes and are listed as such in the museum catalogue, but in a number of cases, specimens labelled and listed as holotypes are not the ones depicted by HeEr, and the quantity of supposed syntypes is greater than the number given in his descriptions.

We found the greatest number of imprints (246, including 121 with HEER's original labels) in the collection of the Geologische Bundesanstalt, Wien (GBA). The most recent inventory was compiled in 2009. All of the specimens were given continuous numbers. In the text of this article we provide the numbers from this latest inventory. It should be noted, however, that in a number of cases the valid names are written on the new labels and in the catalogue incorrectly, because the original labels were misread. For instance, in some cases occulta (the specific epithet of an extant species described from Canada) stands for occultata, and rollari or gottari stand for kollari. This collection contains none of HEER's type specimens.

The third collection is stored in the Naturhistorisches Museum, Wien (NHMW). It contains 145 imprints of ants, with only 82 of them identified to species. The majority of specimens have numbers like 1852.XXIX.30, assigned after the compilation of the inventory in 1852. We refer to these numbers in this article. In this collection we found several specimens which, judging by their old numbers, were studied by MAYR.

Our study of the materials immediately confirmed that MAYR was right in most regards: first, most of the species belong to genera other than those to which they were attributed by HeER; second, in HeER's identifications the same name can stand for more than one species. The record-holder in this respect is the name Formica occultata - eight different species belonging to five genera and three subfamilies are labelled with this name in the collections observed. On the other hand, one species could often be identified as more than a single species. For instance, specimen GBA no. 2009/016/0515 was identified by HeER as Formica longaeva, whereas the counterpart of the same specimen was identified as Formica occultata. HeER distinguished between species on the basis of size-related characters and characters that result from fossilization (coloration of impressions, shape of the gaster). In a number of cases, he erected species based on incorrect interpretations of imprints. Therefore, it was impera- 


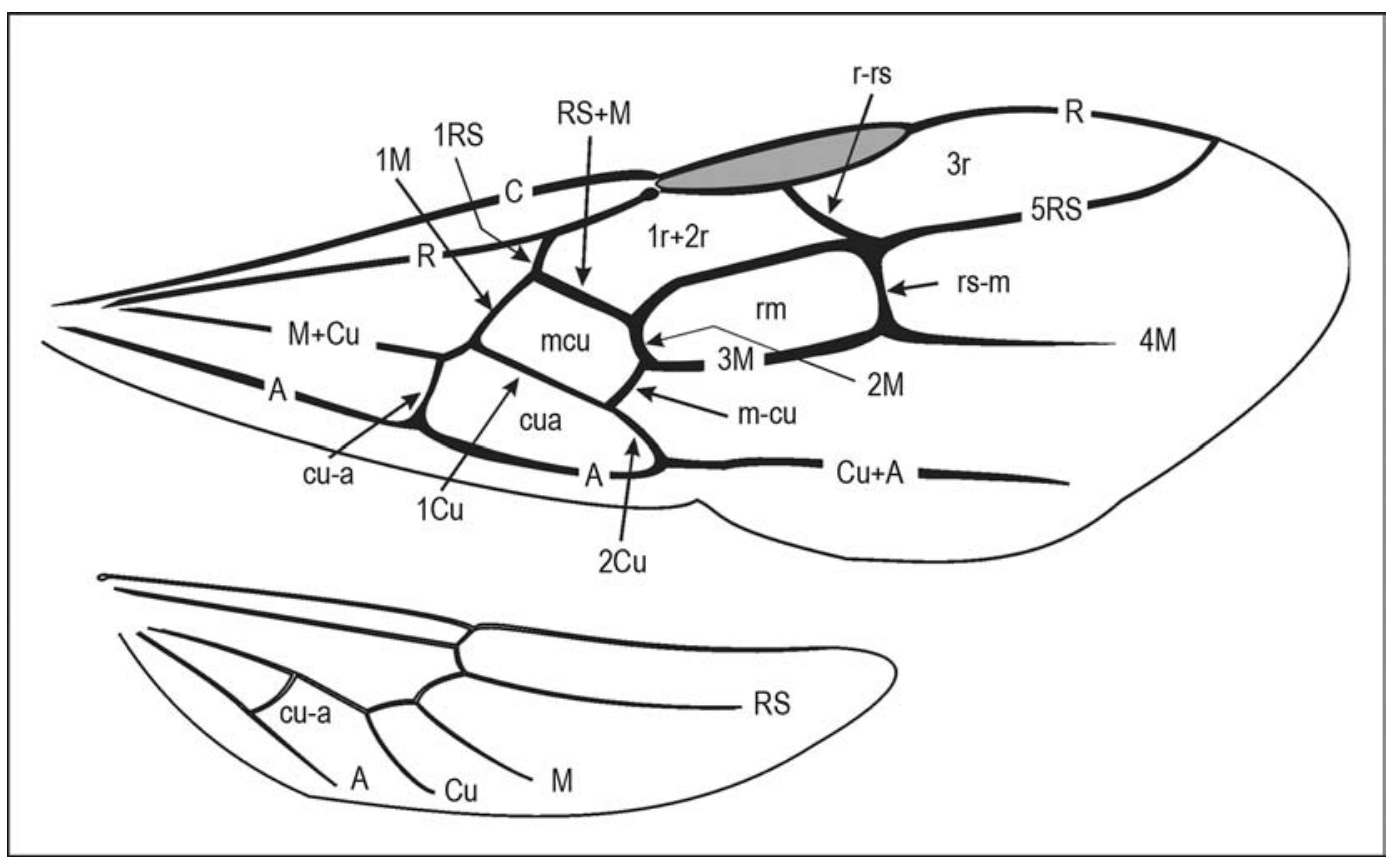

Fig. 1. Wings of gyne of Gnamptogenys europaea (MAYR) (Rovno amber). C, R, RS, M, Cu, A - veins; 1RS, RS+M, 2M etc. - vein sections; $r-r s, r-m, m-c u$ etc. - cross veins; $1 \mathrm{r}+2 \mathrm{r}$, rm, mcu, cua - cells.

tive to designate type specimens and focus the revision on them.

One more important circumstance should be noted here. HeER believed that the deposits of Oeningen and Radoboj were of the same age, and considered seven species (Formica lignitum, F. obesa, F. pinguis, F. pinguicola, F. macrocephala, Poneropsis fuliginosa, and Myrmica tertiaria) common to both sites. However, according to the modern data, the deposits of Radoboj are dated to the Early Miocene, whereas the deposits of Oeningen are dated to the Late Miocene (LuTZ 1997). It is unlikely that any insect species could remain unchanged for several million years.

\section{Methods}

At the beginning of this study we made color digital photographs of all ant specimens. All subsequent work was performed using these photographs. We then determined the type specimens of all species. In a number of cases, we found specimens conforming to the figures in HEER's works. We designated all such specimens as holotypes or lectotypes. When we failed to find such a specimen, we selected as lectotype one of the specimens stored in UMJG\&P, labelled as a syntype and complying with HeER's description and measurements. If no syntype could be found, we desig- nated as neotype the best-preserved specimen that we were certain was identified by HEER and was the best match for his description and measurements. As a result, we determined the types for 54 of the 64 species described by HeER.

Based on the photos, we prepared line drawings of all types and all of the best-preserved specimens. Enlarged prints of the photographs were hand traced by pencil. The resulting draft drawings were scanned and finishing edits were made using the program CorelDraw 15. In the line drawings, full lines indicate visible sclerite boundaries; dashed lines, supposed sclerite boundaries and visible lines other than sclerite boundaries (deformation folds, occasionally superimposed objects, elements of sculpture, etc.); and dotted lines, visible margins of incomplete sclerites. Preserved original sclerites of the impressions are colored in grey, even if these sclerites were chemically modified. Nomenclature of the wing venation (Fig. 1) follows DLussKy (2009). The other morphological terminology is after BoLTON (1994).

Fossil imprints of ants are considerably deformed. Consequently, the calculated measurements and their ratios are more variable than is typical for three-dimensionally preserved ants. Some measurements are less affected by deformation than others (e.g., length of the mesosoma in comparison to its width and height). The gaster in the imprints is usually strongly deformed; therefore, we did not use measurements of the gaster.

The measurements taken are referred to as follows: $\mathrm{AL}$ mesosoma (alitrunk) length from junction with head to that 
with petiole; $\mathrm{AH}$ - mesosoma (alitrunk) height; AW - mesosoma (alitrunk) maximum width; BL - total body length; ED - maximum eye diameter; F3L - hind femur length; FWL - forewing length; GL - gaster length; HL - head length without mandibles; HW - maximum head width; HWL - hind wing length; $\mathrm{Icu}=[1 \mathrm{Cu}+(2 \mathrm{M}+\mathrm{Cu})] / 1 \mathrm{Cu}$ $\mathrm{MdL}$ - mandible length; $\mathrm{n}$ - number of specimens measured; PtL - petiole length; $\mathrm{PtH}$ - maximum petiole height; PtW - maximum petiole width; PptL - postpetiole length; PptW - postpetiole width; ScL - scape length; SctL - scutum length; SctW - scutum width; SctlL - scutellum length; SctlW - scutellum width.

The body length is reported at the beginning of each species description for the following reasons. First, it cannot be measured precisely, because the gaster in the imprints is usually strongly deformed. At the same time, in the process of identification, even an approximate size allows one to immediately exclude a considerably larger or smaller ant species.

\section{Geological setting and preservation of imprints}

The deposits of Radoboj (Croatia) contain one of the richest and most diverse fossil insect assemblages. Several hundred species of different orders have been described from this site (HEER 1847, 1849, 1853, 1867). The deposits of Radoboj are marine deposits accumulated in a shallow epicontinental sea, possibly in a lagoon. In addition to insects, marine fish and algae have been found in Radoboj. The deposits are dated to the Early Miocene (Burdigalian, 16.0-20.4 Ma) (LuTZ 1997; RASNitsyn \& ZHERIKhin 2002). The insect fossils are represented by imprints on finely laminated micritic limestone.

The imprints are rather poorly preserved. In many specimens, the wing venation has not been preserved or has been preserved only partially. The chitin is strongly modified, so that in most cases the sutures of the mesosoma and details of the morphology of the head are not visible. Tarsi, antennal flagella, and mandibular denticles are rarely preserved. None of the specimens displays fine morphological details, such as spurs or setae. As a result, the imprints are relatively hard to identify.

\section{Systematic paleontology}

Family Formicidae LatreilLe, 1809

Subfamily Dolichoderinae ForeL, 1878

Genus Dolichoderus Lund, 1831

Type species: Formica attelaboides Lund, 1831, by monotypy.
Diagnosis (for compression fossils): Gyne. Waist consisting of one segment (petiole); gaster without constriction between first and second gastral (III and IV abdominal) segments. Head elliptical or oval, widest behind midlength of head sides; sometimes retort-shaped or subrectangular with rounded occipital corners, but never rectangular and longer than wide as in Protazteca CARPENTER. Eyes of moderate size. Antennae 12-segmented. Mandibles triangular, dentate. Propodeum bispinate, bidentate, or distinctly angular in side view, always with concave declivity. Petiole with scale proclined, or triangular in side view. Forewing with cells $1+2 \mathrm{r}, 3 \mathrm{r}$, rm and mcu closed; rm usually triangular. Cell $3 r$ touching wing margin. Icu $>1.45$. Integument thick, often coarsely sculptured.

Species numbers and distribution: The genus Dolichoderus comprises 131 species and 20 subspecies in the modern fauna (www.antweb.org, accessed 7 March 2014). The vast majority of these are distributed in the Neotropical, IndoAustralian, and Australian regions. Only nine species are known from the Oriental Region, four from the Nearctic Region and two from the Palaearctic Region, and none have been recorded from the Afrotropical Region. A total of 53 extinct species have been described. The oldest species $D$. kohlsi was recorded from the Middle Eocene Green River Formation, USA (DLUSSKY \& RASNITSYN 2002). Nearly half of the fossil species (24) have been described from Late Eocene European ambers (DLUSSKy 2002, 2008b).

\section{Dolichoderus heeri $\mathrm{n} . \mathrm{sp}$.}

Figs. 2A, 16F

Etymology: The species is named in honour of the palaeoentomologist Oswald HeER.

Studied material: Holotype UMJG\&P no. 77.507 a ( $($, identified by HeER as Formica occultata). Paratypes: UMJG\&P nos. 77.568 ( $\odot$, identified by HeER as F. occultata), 77.569a ( $\odot$, identified by HeER as Formica redtenbacheri). Other specimens: UMJG\&P nos. 77.507b (ơ), 77.569b ((')).

Diagnosis: Differs from the other species from Radoboj in the concave declivity of the propodeum.

Description: Gyne. BL 5-5.5 mm. Head nearly 1.2 times as long as wide, with rounded occipital corners and weakly convex occipital margin. Anterior clypeal margin rounded. Eyes displaced backward, making cheek longer than maximum eye diameter. Mesosoma compact, 1.45 times as long as high. Scutum weakly convex in side view. Propodeum angulate in side view, with straight or weakly convex dorsum and concave declivity. Petiole without scale. Gaster oval. Scutum with longitudinal rugae. Forewing with closed cells $1+2 \mathrm{r}, 3 \mathrm{r}$, rm and mcu. Cell $\mathrm{rm}$ triangular, without peduncle, 1.4 times as long as wide. Cross-veins rs-m and 2r-rs coinciding. Cell mcu rhomboidal, a little longer than wide. $\mathrm{Icu}=1.8$. 


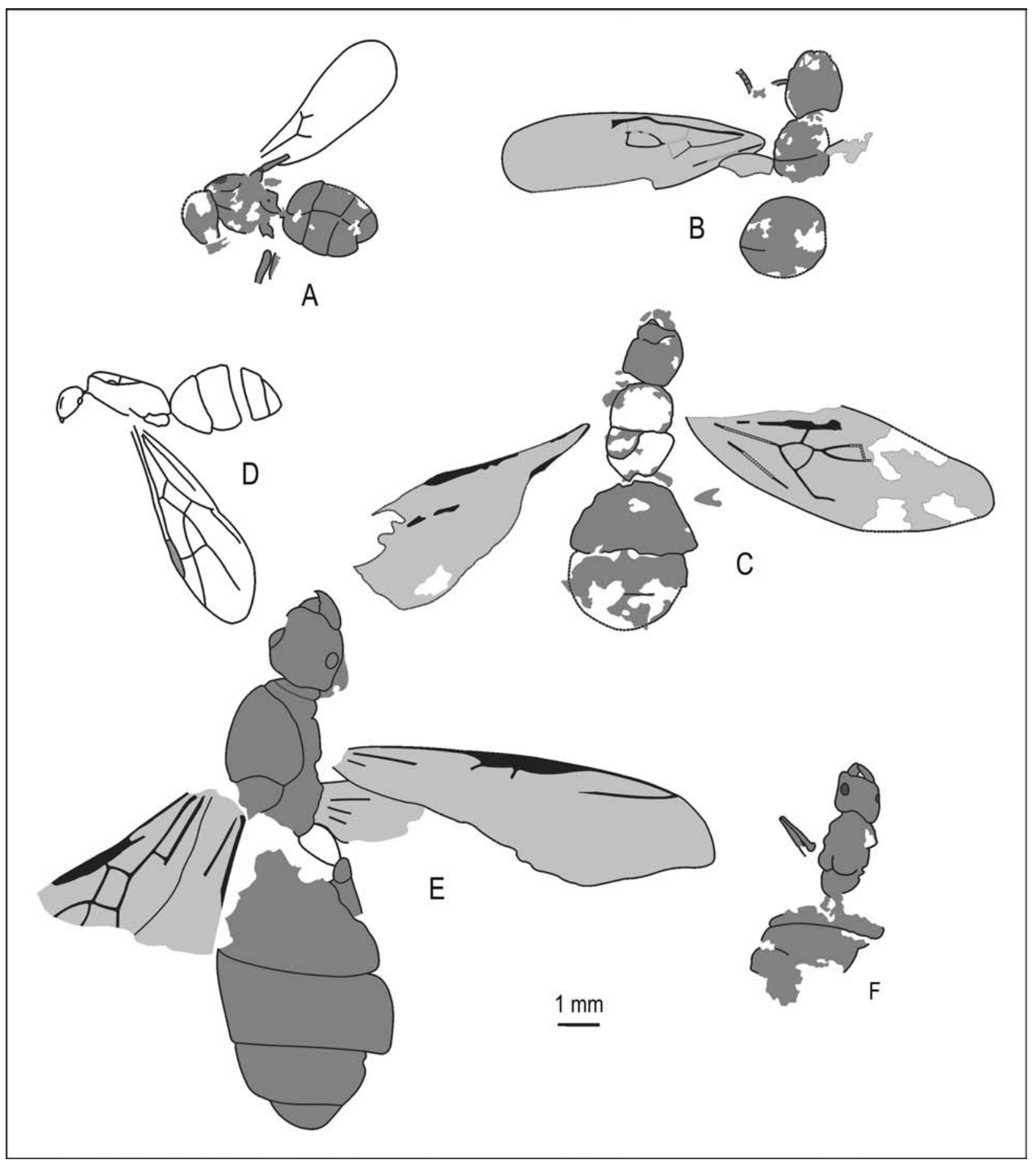

Fig. 2. Species of the subfamily Dolichoderinae. A - Dolichoderus heeri sp. nov., holotype UMJG\&P no. 77.507a (\$); B Emplastus antiquus (MAYr, 1867), neotype GBA no. 2009/016/0459 (P); C - Emplastus dubius sp. nov., holotype UMJG\&P no. 77.527 (P); D - Emplastus haueri (MAYR, 1867) (P, from MAYR, 1867); E - Emplastus miocenicus sp. nov., holotype NHMW no. 1852.XXIX.32 (\%); F - Emplastus (?) ocellus (HeER, 1849), lectotype of Formica ocella HeER, 1849 (\%). 
Measurements, in mm: Gynes: UMJG\&P no. 77.507a (holotype): $\mathrm{BL}=5.4, \mathrm{AL}=1.8, \mathrm{HL}=1.1, \mathrm{FWL}=4.7$; UMJG\&P no. 77.568: $\mathrm{BL}=5.2, \mathrm{AL}=1.7, \mathrm{HL}=\mathrm{HW}=1.0, \mathrm{FWL}=4.8$; UMJG\&P 77.569a: $\mathrm{BL}=5.1, \mathrm{AL}=1.7$. Males: $\mathrm{UMJG} \& \mathrm{P}$ no. 77.507b: $\mathrm{BL}=4.4, \mathrm{AL}=1.25, \mathrm{HW}=0.7, \mathrm{FWL}=4.4$; UMJG\&P no. 77.569b: $\mathrm{BL}=4.4, \mathrm{AL}=1.4, \mathrm{HW}=0.7, \mathrm{FWL}=4.1$.

Remarks: Two males are present together with gynes on the same pieces of rock. They are very poorly preserved, so we cannot describe them. However, as their size corresponds to the expected size of $D$. heeri males, we tentatively identified them as males of this species.

\section{Morphogenus Emplastus DonisTHORPE, 1920}

\section{Type species: Emplastus emeryi DonisTHorpe, 1920, by} original designation.

Diagnosis: Fossil ants not preserved well enough to fit orthotaxa, and with the following combination of traits: size medium; waist consisting of one segment (petiole); gaster without constriction between first and second gastral (III and IV abdominal) segments; head subrectangular with rounded occipital corners; antennae 12-segmented in gynes and workers and 13-segmented in males; scape of males short; mandibles triangular with denticulate masticatory margin; propodeum rounded in side view, petiole in side view with thick scale (workers and gynes) or triangular (males). Forewing with cells $1+2 \mathrm{r}, 3 \mathrm{r}$, rm and mcu closed; cell $3 \mathrm{r}$ with apex touching wing fore margin, $1 \mathrm{RS}$ vertical to $\mathrm{R}$ or slightly proclined. Icu $>1.45$.

Species numbers and distribution: Recently, four species from Bembridge, UK (Late Eocene or Early Oligocene marls), were included in this genus (Dlussky \& Perfilieva 2014), however, evidently some fossil species described as Iridomyrmex, Hypoclinea, Liometopum, etc. should also be placed into Emplastus.

Remarks: Donisthorpe (1920) placed this genus into the subfamily Ponerinae and considered it similar to the modern Myopias RoGER, 1861. In his opinion, Emplastus, as well as Myopias, has mandibles without teeth. In fact the holotype of E. emeryi has the masticatory margin of its mandibles hidden. Other specimens similar to E. emeryi in terms of body proportions and other visible characters have the masticatory margin of the mandibles visible but with blunt teeth. The position of the cross-vein cu-a in the type species $(\mathrm{Icu}=1.7)$ differs clearly from that of Ponerinae (DLussky \& Perfilieva 2014). Cockerell (1915) and Donisthorpe (1920) described several species now included in Emplastus based on the Dolichoderus-like forewing venation (characteristic of several other dolichoderine genera). However, this character is combined with the propodeum being rounded in side view and not angular or bispinate with concave hind contour, as in all living and fossil Dolichoderus. Recently, these species were transferred to Emplastus (DLussky \& Perfilieva 2014).

\section{Emplastus antiquus (MAYR, 1867) n. comb.} Figs. 2B, 16B

1867 Liometopum antiquum MAYR, p. 60, fig. 10 (\$).

1907 Liometopum antiquum MAYR, 1867. - HaNDLIRSCH, p. 870.

1995 Liometopum antiquum MAYR, 1867. - Bolton, p. 247.

Studied material: Neotype (designated here), GBA no. 2009/016/0459 ( $\%$, identified by HeER as Formica globularis).

Diagnosis: Differs from all other Emplastus species from Radoboj in the concave occipital margin of the head (occipital margin of the other species is weakly convex). $E$. britannicus (COCKERELL, 1915) from Late Eocene deposits of Bembridge has a concave occipital margin, but it is larger (BL 6-8.5 mm); it also has a short (not reaching occipital margin) scape and the forewing nearly as long as the body.

Description: Gyne. BL 5-6 mm. Head 1.08 times as wide as long, with convex sides and concave occipital margin. Scape reaching occipital margin or slightly protruding beyond it. Middle joints of funiculus nearly as long as wide. Mesosoma moderately wide. Forewings longer than body. Cell rm triangular, pedunculate. Gaster roundish.

Measurements of neotype, in mm: $\mathrm{BL}=5.8, \mathrm{AL}=1.9$, $\mathrm{HL}=1.3, \mathrm{HW}=1.4, \mathrm{FWL}=6.7$.

Remarks: MAYR (1867) formally described this species from two specimens as Formica globularis. We found no syntypes of MAYR's species in any of the collections studied, but one of the specimens identified by HeER as Formica globularis (GBA no. 2009/016/0459, old number 337) proved similar to the description of Liometopum antiquum. We designate this specimen as the neotype. The venation of the forewing is only partly preserved, but a triangular cell $\mathrm{rm}$ is clearly visible, indicating the placement of this species in Dolichoderinae, rather than Formicinae.

MAYR placed this species in the genus Liometopum based on the concave occipital margin of the head, but now species with a convex occipital margin are known also in other genera. Since the imprint displays no other characters unambiguously indicating the placement of this species in Liometopum, we suggest transferring it to the form genus (morphogenus) Emplastus.

\section{Emplastus dubius n. sp.}

Figs. 2C, 16D

Etymology: Dubius is the Latin word for uncertain.

Studied material: Holotype UMJG\&P no. 77.527 ( $\%$, identified by HeER as Formica globularis).

Diagnosis: Differs from the other known species of Emplastus in forewing venation. All the other species have a rectangular cell $\mathrm{mcu}$ and cell $\mathrm{rm}$ without peduncle. 
Description: Gyne. BL $7.5 \mathrm{~mm}$. Head a little longer than wide. Mesosoma nearly as wide as head and 1.6 times as long as wide. Scutellum longer than wide. Gaster oval. Forewing venation poorly preserved. Cell rm triangular, narrow, pedunculate. Cell mcu trapezoidal. Section $1 \mathrm{M}$ nearly as long as $2 \mathrm{RS}$.

Measurements of holotype, in mm: $\mathrm{AL}=2.3, \mathrm{HL}=1.4$, $\mathrm{HW}=1.3, \mathrm{FWL}=6.8$.

Emplastus haueri (MAYR, 1867) n. comb. Fig. 2D

1867 Hypoclinea haueri MAYR, p. 60, fig. 11 (ㅇ).

1893 Iridomyrmex haueri (MAYR, 1867). - DAlla TORRE, p. 169.

1907 Iridomyrmex haueri (MAYR, 1867). - HANDLIRSCH, p. 871.

1992 Iridomyrmex haueri (MAYR, 1867). - SHATTUCK, p. 15.

1995 Iridomyrmex haueri (MAYR, 1867). - Bolton, p. 218.

Diagnosis: Differs from the other described species of Emplastus in the elongate metasoma.

Description (from MAYr, 1867): Gyne. BL $5.8 \mathrm{~mm}$ (head $1 \mathrm{~mm}$, mesosoma $2 \mathrm{~mm}$, gaster $2.8 \mathrm{~mm}$ ), forewing $5.4 \mathrm{~mm}$. Head small. Mesosoma very elongate and weakly convex. Gaster oval.

Remarks: MAYR (1867) formally described this species from one specimen identified by HeER as Formica occultata. We have found neither the holotype nor specimens similar to it in the studied collections. Judging by the size ( $\mathrm{AL}=2.2, \mathrm{FWL}=5.7 \mathrm{~mm}$ ) and venation of the forewing, the poorly preserved male GBA no. 2009/016/0429 may also belong to this species. Since the diagnostic characters of the genus Iridomyrmex are not visible in that specimen, we transfer this species to the form genus Emplastus.

\section{Emplastus miocenicus n. sp.}

Figs. 2E, 16E

Etymology: Named after the Miocene.

Studied material: Holotype NHMW no. 1852.XXIX.32 ( $q$, identified by HeEr as Ponera fuliginosa). Paratype UMJG\&P no. 77.485 ( $\%$, identified by HeER as Formica ungeri).

Diagnosis: Similar to E. haueri, but differs in the larger size.

Description: Gyne. BL $13.5 \mathrm{~mm}$. Head 1.05 times as long as wide, with rounded occipital corners and weakly convex occipital margin. Anterior clypeal margin rounded. Eyes oval, situated at midlength of head sides; gena longer than maximum eye diameter. Mandibles triangular with dentate masticatory margin. Mesosoma nearly as wide as head. Scutum longer than wide. Gaster oval. Forewing with cell rm triangular, comparatively wide, without peduncle. Cell mcu rectangular, 1.6 times as long as wide. Section 1M much longer than $1 \mathrm{RS}$. Icu=1.9.

Measurements, in mm: Holotype NHMW no. 1852. XXIX.32: $\mathrm{BL}=13.5, \mathrm{AL}=3.9, \mathrm{HL}=1.8, \mathrm{HW}=1.7, \mathrm{FWL}=10.1$; paratype UMJG\&P no. 77.485: $\mathrm{AL}=3.8, \mathrm{FWL}=9.0$.

Remarks: In the new label (and possibly also in the catalogue) specimen UMJG\&P no. 77.485 is marked as the holotype of Formica ungeri. This is clearly a mistake. First, $F$. ungeri was described from ten specimens, and HeER designated no holotypes. Second, the specimen is similar to none of the four specimens depicted in HEER's monograph.

\section{Emplastus (?) ocellus (HeER, 1849) n. comb.} Fig. 2F

1849 Formica ocella HeER, p. 133, pl. 10, fig. 5a, b, pl. 11, fig. 14 a, b (o').

1849 Formica ocella var. paulo major HeER, p. 133, pl. 10 , fig. $5 \mathrm{c}$, pl. 9 , fig. $14 \mathrm{c}\left(\mathrm{o}^{\top}\right)$.

non 1907 Formica ocella Heer, 1849. - Handlirsch, p. 864.

non 1995 Formica ocella Heer, 1849. - Bolton, p. 200.

Studied material: Lectotype of Formica ocella UMJG\&P no. 77.645a ( $\%$, designated here, figured by HEER 1849: pl. 10, fig. 5a). Paralectotypes of $F$. ocella UMJG\&P no. 77.645 b (20', figured by HeER 1849: pl. 10, fig. 5b). Holotype of $F$. ocella var. paulo major UMJG\&P no. 77.645 c (o', figured by HeER 1849: pl. 10, fig. 5c)

Diagnosis: Gyne differs from all of the ants known from Radoboj in the shape of the head.

Description: Gyne. BL $6.2 \mathrm{~mm}$. Head longer than wide, with parallel sides, rounded occipital angles and concave occipital margin. Anterior margin of clypeus straight. Eyes oval, situated in front of lateral midlength of head. Gena is nearly as long as maximum eye diameter. Mandibles curved; dentition of masticatory margin not visible. Mesosoma elongate, nearly twice as long as wide. Appendages, petiole and wings not preserved, gaster strongly deformed.

Male. BL 4.9-5.6 mm. Head wider than long. Mesosoma 1.5 times as long as wide and 1.6 times as long as high. Scutum 1.2 times as wide as long. Scutellum 1.3 times as wide as long. Propodeum angulate in side view; with very short dorsal part and straight declivous part. Petiole triangulate in side view, 1.3 times as high as long.

Measurements, in mm: UMJG\&P no. 77.645a ( $\%$, lectotype): $\mathrm{AL}=2.1, \mathrm{HL}=0.99, \mathrm{HW}=1.08$; UMJG\&P no. $77.645 \mathrm{~b}$ $\left(\sigma^{7}\right): \mathrm{AL}=1.9, \mathrm{AW}=1.25, \mathrm{SctL}=0.8, \mathrm{SctW}=1.0, \mathrm{SctlL}=0.55$, SctlW=0.7, F3L=1.5; UMJG\&P no. 77.645c (o'): $\mathrm{AL}=1.9$, $\mathrm{SctL}=0.9$, SctlL=0.5. 


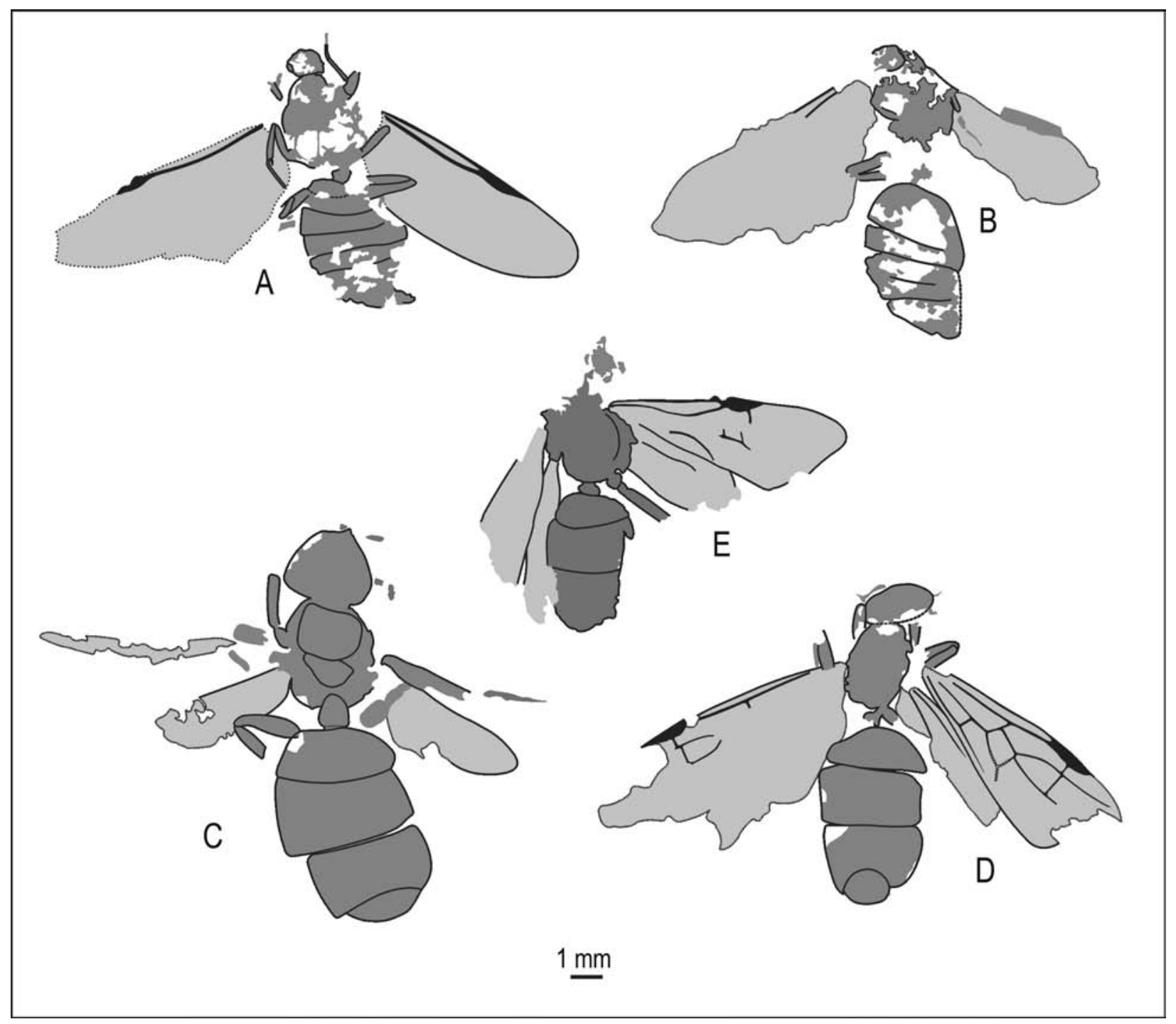

Fig. 3. Liometopum imhoffii (HeER, 1849). A - Neotype of Formica imhoffii HeER, 1849, GBA no. 2009/016/0238 (ơ); B - lectotype of Formica schmidtii HeER, 1849, UMJG\&P no. 77.594 (o'); C - lectotype of Ponera fuliginosa radobojana Heer, 1849, UMJG\&P no. 77.592 (P); D - holotype of Ponera affinis HeER, 1849, UMJG\&P no. 77.638 (\%); E - neotype of Poneropsis lugubris HeER, 1867, NHMW no. 1852.XXIX.35 (ơ).

Remarks: HeER described this species from four specimens found in the same piece of rock together with imprints of other ants. He considered them to be two pairs in copula at the time of death. We designate as the lectotype specimen UMJG\&P no. 77.645 a, depicted in pl. 10, fig. 5a. Although the figure is small and very imprecise, it follows from the text that the description of the gyne is based on this specimen (the unusual shape of the mandibles and eyes shifted forward are noted; the size of the specimen also complies with the description). The other gyne has been preserved so poorly that it is impossible to identify it to genus. There is a lateral imprint of a male within the same piece of rock, described by HeER as Formica ocella var. paulo major, indicating that it is distinguished by the larger size and more elongate body. However, the difference in size is actually caused by the strongly deformed gaster of this specimen. The length of the mesosoma, which has deformed less strongly in the course of fossilization, is approximately identical in this specimen and in the two males described as $F$. ocella.

MAYR (1867) examined two poorly preserved specimens identified by HeER as Formica ocella, and could not determine to which genus they belonged. Therefore, HandLIRSCH (1907) left this species in the genus Formica. 
The gyne of this species differs from all of the other ants from Radoboj in the structure of the head so strongly that it is doubtlessly a separate species. At the same time, the specimen is so poorly preserved that it is impossible to determine to which genus it belongs, or to describe a new genus for this species. Based on the similarity of the anterior margin of the clypeus of this ant to those of many members of Dolichoderinae, we have provisionally placed it in the morphogenus Emplastus.

\section{Genus Liometopum MAYR, 1861 (= Poneropsis HeER, 1867)}

Type species: Ponera fuliginosa HeER, 1867 by subsequent designation of WHEELER 1911, n. syn.

Type species: Formica microcephala PANZER, 1798, by monotypy.

Diagnosis (for compression fossils): Size large or medium. Waist consisting of one segment (petiole); gaster without constriction between first and second gastral (III and IV abdominal) segments. Head of gyne wider than long, with concave occipital margin. Antennae geniculate in both sexes, 12-segmented in gynes and workers and 13-segmented in males. Scape of male short. Declivitous part of propodeum stright or convex (not concave) in side view. Petiole with scale in gynes and triangulate in side view in males. Male genitalia large, not involved. Forewing with closed cells $1+2 \mathrm{r}, 3 \mathrm{r}$, rm and mcu; cell $3 \mathrm{r}$ with apex removed from anterior margin of wing. Icu $>1.45$

Species numbers and distribution: Seven living species are distributed in temperate and subtopic zones of Eurasia and North America (Shattuck 1992). Eight fossil species have been described: L. oligocenicum WHEELER, 1915 (Baltic amber, Late Eocene), L. miocenicum CARPENTER, 1930, L. scudderi CARPENTER, 1930 (Florissant, Oligocene), L. eremicum ZHANG, 1989, L. patamophilum ZHANG, 1989, L. lubricum Zhang, Sun \& Zhang, 1994 (Shanwang, Miocene), and the two species from Radoboj re-described below.

Remarks: HeER (1867) included all ants that had a onesegmented waist and forewings with closed cells $1+2 \mathrm{r}$, $3 \mathrm{r}$, rm and $\mathrm{mcu}$ in the genus Poneropsis. Such a diagnosis (later repeated by TAYLOR 1964) fits most genera of Ponerinae and Dolichoderinae. WHEELER (1911) designated Ponera fuliginosa HeER as the type species of Poneropsis. MAYR (1867) studied three poorly preserved specimens identified by Heer as P. fuliginosa (not types) and found that they had a two-segmented waist and were outwardly similar to Aphaenogaster (Myrmicinae). We have studied four syntypes of this species and found that three of them undoubtedly belong to the genus Liometopum and one is poorly preserved and possibly also belongs to that genus. Therefore, the genus Poneropsis Heer, 1867 is junior synonym of Liometopum MAYr, 1861.

\section{Liometopum imhoffii (HEER, 1849)}

Figs. 3A-E, 16A

1849 Formica imhoffii HeER, p. 138, pl. 10, fig. 10 (ơ).

1849 Formica schmidtii HeER, p. 138, pl. 11, fig. 5b, c (ơ).

1849 Ponera fuliginosa radobojana HeER, p. 146, pl. 12, fig. 1a-d (P), n. syn.

1849 Ponera affinis HeEr, p. 147, pl. 12, fig. 2 (\%), n. syn.

1867 Poneropsis affinis (Heer, 1849). - Heer, p. 19, n. syn.

1867 Poneropsis fuliginosa (HeER, 1849). - HeER, p. 19, n. syn.

1867 Poneropsis lugubris Heer, p. 21, pl. 1, fig. 23b, c (ơ), n. syn.

1867 Poneropsis lugubris var. minor HeER, p. 21, n. syn.

1867 Poneropsis imhoffii (HeER, 1849). - HeER, p. 24, pl. 2, fig. 3 .

1867 Poneropsis schmidtii (HeER, 1849). - Heer, p. 24, pl. 2, fig. 4.

1867 Poneropsis livida Heer, p. 25, pl. 2, fig. 5 (ơ), n. syn.

1867 Poneropsis morio Heer, p. 26, pl. 2, fig. 6 b (\%), n. syn.

1867 Poneropsis morio var. pallens HeER, 1867, p. 26, pl. 2 , fig. $6 \mathrm{c}\left(\mathrm{o}^{\mathrm{r}}\right)$, n. syn.

1867 Aphaenogaster fuliginosa (HEER, 1849). - MAYR, p. 57, n. syn.

1867 Aphaenogaster livida (HeER, 1867). - MAYr, p. 57, n. syn.

1867 Liometopum imhoffii (HeER, 1849). - Mayr, p. 55.

1907 Liometopum imhoffii (HeER, 1849). - HaNDLIRSCH, p. 870.

1907 Liometopum schmidtii (Heer, 1849). - Handlirsch, p. 871.

1907 (Dolichoderidae) morio (HeER, 1867). - HANDLIRSCH, p. 871, n. syn.

1907 (Dolichoderidae) lugubris (HeER, 1867). - HandLIRSCH, p. 872, n. syn.

1907 Aphaenogaster fuliginosa (HeER, 1849). - HANDLIRSCH, p. 874, n. syn.

1907 Aphaenogaster livida (HEER, 1867). - HANDLIRsch, p. 874, n. syn.

1907 (Poneropsis) affinis (HeER, 1849). - Handuirsch, p. 880, n. syn.

1907 Poneropsis lugubris var. minor HeER, 1867. - HaNDLIRSCH, p. 880, n. syn.

1907 Poneropsis morio var. pallens (HEeR, 1867). - HANDLIRSCH, p. 881, n. syn.

1964 Poneropsis fuliginosa (HeER, 1849). - TAYLoR, p. 138 , n. syn.

1994 Liometopum imhoffii (HeER, 1849). - Shattuck, p. 129.

1995 Aphaenogaster livida (HeER, 1867). - Bolton, p. 70, n. syn.

1995 Liometopum imhoffii (Heer, 1849). - Bolton, p. 247.

1995 Poneropsis affinis (HeER, 1849). - Bolton, p. 363, n. syn.

1995 Poneropsis fuliginosa (Heer, 1849). - Bolton, p. 363, n. syn.

1995 Poneropsis lugubris Heer, 1867. - Bolton, p. 363, n. syn. 
1995 Poneropsis lugubris var. minor HeER, 1867. Bolton, p. 363, n. syn.

1995 Poneropsis morio Heer, 1867. - Bolton, p. 363, n. syn.

1995 Poneropsis pallens: (HeER, 1867). - Bolton, p. 363, n. syn.

Studied types: Neotype (designated here) of Formica imhoffii GBA no. 2009/016/0238 (o'). Lectotype (designated here) of Formica schmidtii UMJG\&P no. 77.594 (o', figured in pl. XI, fig. 5c). Lectotype (designated here) of Ponera fuliginosa: UMJG\&P nos. *77.592 (\$),*77.593 (\%, counterpart of the same specimen) (labelled as syntypes). Holotype of Ponera affinis: UMJG\&P no. 77.638 (\%). Neotype (designated here) of Poneropsis lugubris: NHMW no. 1852. XXIX.35 (o').

Other studied material: GBA: 2009/016/0092 (P), 2009/016/0146 (\%), 2009/016/0552b (९). UMJG\&P: 77.491

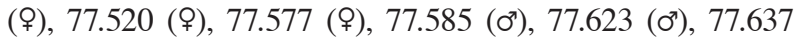
(९). NHMW: 1852.XXIX.37 (?), 1843.XLIX.3 ((), 1877. XXV.18a (2क), K.K. Polytechn. Institut, 1868 (ơ), Jahr 1868 $\left(\sigma^{7}\right)$, on without number.

Diagnosis: Differs from L. eremicum and L. patamophilum from the Miocene deposits of Shanwang (ZHANG, 1989) in the wing venation: $L$. eremicum with pedunculate cell $\mathrm{rm}$, and cell $\mathrm{rm}$ of $L$. patamophilum more than twice as long as wide (in $L$. imhoffii, cell $\mathrm{rm}$ is not pedunculate and 1.6 times as long as wide). Differs from $L$. miocenicum and $L$. scudderi from Oligocene deposits of Florissant (CARPENTER 1930) in the shape of the head of gynes (the head in these species is longer than wide, with a straight occipital margin).

Description: Gyne. BL 11.5-13.3 mm. Head 1.2-1.4 times as wide as long, with convex sides and concave occipital margin. Mesosoma wider than head, robust, 1.3-1.6 times as long as wide. Scutum large, 1.3-1.4 times as wide as long. Scutellum transverse. Legs rather short and thick. Petiole with wide scale, oviform in side view, nearly two times as wide as long. Gaster oval. Forewing as in genus. Cell rm rather large, triangular, without pedicel, nearly twice as long as wide. Cell mcu rectangular, 1.6 times as long as wide. $\mathrm{Icu}=1.6$.

Male. BL 8.5-9.5. Mesosoma noticeably wider than head, robust, 1.3-1.5 times as long as wide. Scutum large, wider than long. Scutellum transverse. Legs longer and thinner than in gyne. Petiole triangulate in side view, nearly as long as high, and 1.5 times as long as wide. Gaster oviform. Forewing as in gyne.

Measurements, in mm: Gynes. UMJG\&P no. 77.491 (lectotype): $\mathrm{AL}=3.8, \mathrm{AW}=3.0, \mathrm{PtL}=0.6, \mathrm{PtW}=1.2, \mathrm{FWL}=10.7$; GBA no. 2009/016/0146: $\mathrm{AL}=3.5, \mathrm{AW}=2.25, \mathrm{Sct}=1.4$, $\mathrm{SctW} 1.8$, SctlL=0.65, SctlW=1.4, FWL=8.4; GBA no. 2009/016/0552b: AL=3.2, AW=2.3, PtW=0.8; UMJG\&P no. 77.520: $\mathrm{AL}=3.0$; $\mathrm{UMJG} \& \mathrm{P}$ no. 77.577: $\mathrm{BL}=11.5, \mathrm{AL}=3.3$; UMJG\&P no. 77.592: $\mathrm{BL}=12.7, \mathrm{AL}=3.8, \mathrm{AW}=2.9, \mathrm{HL}=2.0$, $\mathrm{HW}=2.7, \quad \mathrm{SctL}=1.6, \quad \mathrm{SctW}=2.0, \quad \mathrm{Sctl} \mathrm{L}=1.6, \quad \mathrm{SctlW}=2.0$, $\mathrm{F} 3 \mathrm{~L}=2.4$; UMJG\&P no. 77.593: $\mathrm{BL}=12.6, \mathrm{AL}=3.8, \mathrm{AW}=2.2$,
SctL=1.5, SctW=2.1, PtL=0.6, PtW=1.0; UMJG\&P no. 77.638: $\mathrm{AL}=2.7, \mathrm{AW}=1.9$.

Males: GBA no. 2009/016/0238: $\mathrm{BL}=8.7, \quad \mathrm{AL}=3.1$, $\mathrm{AW}=2.35$, FWL=8.7; UMJG\&P.77.585: $\mathrm{AL}=3.5$; UMJG\&P no. 77.594: $\mathrm{AL}=3.25, \mathrm{AW}=2.7$; NHMW no. 1843.XLIX.3: $\mathrm{BL}=8.4, \mathrm{AL}=3.0, \mathrm{AH}=2.3$; NHMW no. 1852.XXIX.35: $\mathrm{AL}=3.2, \mathrm{PtL}=0.4, \mathrm{PtW}=0.6, \quad \mathrm{FWL}=7.7$; NHMW without number: $\mathrm{BL}=9.5, \mathrm{AL}=3.6, \mathrm{AH}=2.4, \mathrm{PtL}=\mathrm{PtH}=0.6$, $\mathrm{F} 3 \mathrm{~L}=2.2$.

Remarks: Originally Heer (1849) described two species as Formica imhoffii and F. schmidtii, but subsequently transferred them to the genus Poneropsis. He labelled specimens belonging to these species either as Formica, or as Formica (Ponera), or as Ponera. The former species was described by HeER from three males. The collection of UMJG\&P contains specimen no. 77.491, labelled as syntype, but it cannot be considered a syntype, because it is an imprint of a gyne, rather than a male. We designate here as the neotype the specimen NHMW 2009/016/0238, identified by HEER as Ponera imhoffii and complying with the description. Formica schmidtii was described from two males. The collection of UMJG\&P contains five specimens labelled as syntypes. One of them is a gyne, and one (identified with a question mark) does not even belong to Hymenoptera; therefore, these two can by no means be considered syntypes. The other three specimens are males and one of them (UMJG\&P no. 77.594) matches with HEER's figure (1849: pl. 11, fig. 5c). We designate this specimen as the lectotype. MAYR (1867) studied two specimens identified by HeER as Ponera imhoffii and six specimens identified as Ponera schmidtii and concluded that the two specimens of $P$. imhoffii and the three specimens of $P$. schmidtii are actually males of the same species of the genus Liometopum. In accordance with this view, HandLIRSCH (1907) synonymised these two species and transferred them to the genus Liometopum. Having examined the type specimens, we have come to the same conclusion as MAYR did.

Heer (1849) originally described Ponera fuliginosa based upon three gynes from Oeningen as P. fuliginosa oeningensis (p. 145), and then from four gynes from Radoboj as $P$. fuliginosa radobojana (p. 146). The collection of UMJG\&P contains three specimens, two of them labelled as syntypes (nos. 77.593 and 77.637), and one (no. 77.592) as the holotype. Specimen no. 77.593 is the counterpart of no. 77.592. None of the specimens complies with HeER's figures; therefore, we designate specimens nos. 77.592 and 77.593 as the lectotype, since HeER designated no holotypes. The individual impressed in these specimens is similar to HeER's description and figures and doubtlessly represents a gyne of the genus Liometopum. MAYR (1867) studied three specimens identified by HeER as Ponera fuliginosa and found that they had a two-segmented waist and were outwardly similar to Aphaenogaster. Based on these observations, HaNDLIRSCH (1907) transferred this species in the genus Aphaenogaster. However, the specimens examined by MAYr were not types, and HeER's figures clearly show that this species has a one-segmented waist and wing venation typical of Dolichoderinae.

The single specimen described by HeER as Ponera affinis has been preserved (UMJG\&P no. 77.638) and we des- 
ignate it as the holotype. HeER wrote that this species was very similar to $P$. fuliginosa, from which it differed in the more oval head, more elongate gaster, and shorter wings. In fact, the head of the imprint is strongly deformed, and the gaster became elongate postmortem as a result of pressure, making the wing length smaller relative to the body length. Otherwise, the holotype of this species does not differ in any visible characters from the lectotype of $P$. fuliginosa. In a later study HeER (1867) transferred this species to the genus Poneropsis. MAYR failed to find specimens of this species, and therefore HANDLIRSCH (1907) provisionally left it in that genus.

HeEr (1867) described Poneropsis lugubris from two males, which have not been preserved. We found only one specimen identified by HeER (NHMW no. 1852.XXIX.35), which we designate as the neotype. It is a little smaller than indicated in the description, but similar in general habitus to HEER's figures and displays no difference from Liometopum in outward characters. Judging by the figures and description, the specimens described by HeER also belong to this genus, as also suggested by HEER's remark at the end of the description: "Dürfte vielleicht als Männchen zu der Poneropsis fuliginosa gehören". On the same page, HeEr described $P$. lugubris var. minor, which, judging by the description, differs only in the a little smaller size (body length 8.8, rather than $9.9 \mathrm{~mm}$ ). MAYR (1867) studied five specimens identified by HEER as P. lugubris and wrote that judging by wing venation they belong to the subfamily Dolichoderinae. In the catalogue by HANDLIRSCH they are listed as (Dolichoderidae) lugubris (p. 872) and Poneropsis lugubris minor (p. 880), but BolToN (1995) left this species in the genus Poneropsis.

We found no differences in preserved characters between males of Liometopum, described by HEER as Formica imhoffii, F. schmidtii and Poneropsis lugubris, and between gynes of this genus, described by him as Ponera fuligino$s a$ and $P$. affinis. HeER noted the similarity between these species and distinguished between them based on size and minor differences in the shape of the head, mesosoma, and gaster. In fact, the differences in size between these species are safely within the limits of intraspecific variation of Recent Liometopum (body length of L. microcephalum 9-11 $\mathrm{mm}$ in gynes and 8-10 $\mathrm{mm}$ in males), and the differences in the shape of the mesosoma and gaster revealed by HeER result from deformation in the course of fossilization. The ratios of gyne and male size in Liometopum specimens from Radoboj are identical to those found in extant species of the genus. Therefore, we believe that it is reasonable to regard them as members of a single species. In addition, we believe that it is reasonable to regard the two species and one variety - the types of which we have not seen (Poneropsis livida, $P$. morio and $P$. morio var. pallens) - as junior synonyms of Liometopum imhoffii.

HeEr (1867) described Poneropsis livida from a single specimen, which has not been preserved. He considered it a gyne, but it can be seen from the figure that actually it was a male with a small head and short scape. HEER wrote that this specimen "vielleicht gehört es als solches zu der Poneropsis schmidtii", a statement with which we agree, judging by the figure. In the collection of GBA we found ten imprints identified as $P$. livida (three of them identified with certainty and bearing HeER's labels). One of these imprints represents a male Formica ungeri, and the others are so poorly preserved that it makes their identification impossible. MAYR (1867) saw two specimens identified by HEER and suggested that they could represent males of Aphaenogaster. Based on this suggestion, HandLIRSCH (1907) placed this species in the genus Aphaenogaster. However, the male depicted in HEER's figure could by no means belong to this genus and doubtlessly represents the genus Liometopum.

HeEr (1867) described a gyne of Poneropsis morio and a male of $P$. morio var. pallens from one specimen each. We found in the studied collections two specimens identified by HeER as $P$. morio, but they comply neither with the descriptions nor with the figures provided by HEER and clearly belong to other species. MAYR (1867) examined two specimens identified by HeER as $P$. morio and considered them males of Dolichoderinae, but they were so poorly preserved that he could not identify them to genus. In the catalogue of HandLIRSCH (1907) these subspecies were listed as a gyne (Dolichoderidae) morio (p. 871) and a male Poneropsis morio pallens (p. 881). In the catalogue of BolTon (1995) they were listed as the separate species $P$. morio and $P$. pallens. In our opinion, HeER's figures depict a gyne and a male Liometopum indistinguishable by their visible characters from Liometopum imhoffii.

\section{Subfamily Formicinae LATREILLE, 1809 Genus Attopsis HeER, 1849}

Type species: Attopsis longipennis HeER, 1849, by subsequent designation of WHEELER 1911: 159.

Diagnosis: Gyne. Waist consisting of one segment (petiole); gaster without constriction between first and second gastral (III and IV abdominal) segments. Pronotum, propodeum and petiole armed with paired spines. First gastral segment nearly as long as second. Forewings long, greatly protruding over gastral tip; cell $3 \mathrm{r}$ closed, cell $\mathrm{rm}$ and perhaps mcu absent; sections 5RS and 4M with joint start (cross-vein rs-m absent).

Attopsis is similar in the presence of spines on the mesosoma and petiole and in wing venation to Polyrhachis F. SмIтH, 1857. However, in Polyrhachis, the first gastral segment is considerably bigger than the others and makes up almost half of the gaster, whereas in Attopsis longipennis, it is subequal to the second segment.

\section{Species included: Type species, known from Radoboj.}

Remarks: According to HeER's diagnosis, the genus Attopsis is characterized by a two-segmented waist and by forewing venation rare among Myrmicinae: the cells rm and mcu are absent and the distal branches of RS and M diverge from a common point. Among the 18 examined specimens placed by HeER in the genus Attopsis, only two had two-segmented waists, but their wing venation differed from that described by HeEr. We placed these two specimens in the genus Paraphaenogaster. In the other specimens, except the holotype of A. longipennis, either a one-segmented waist with an 


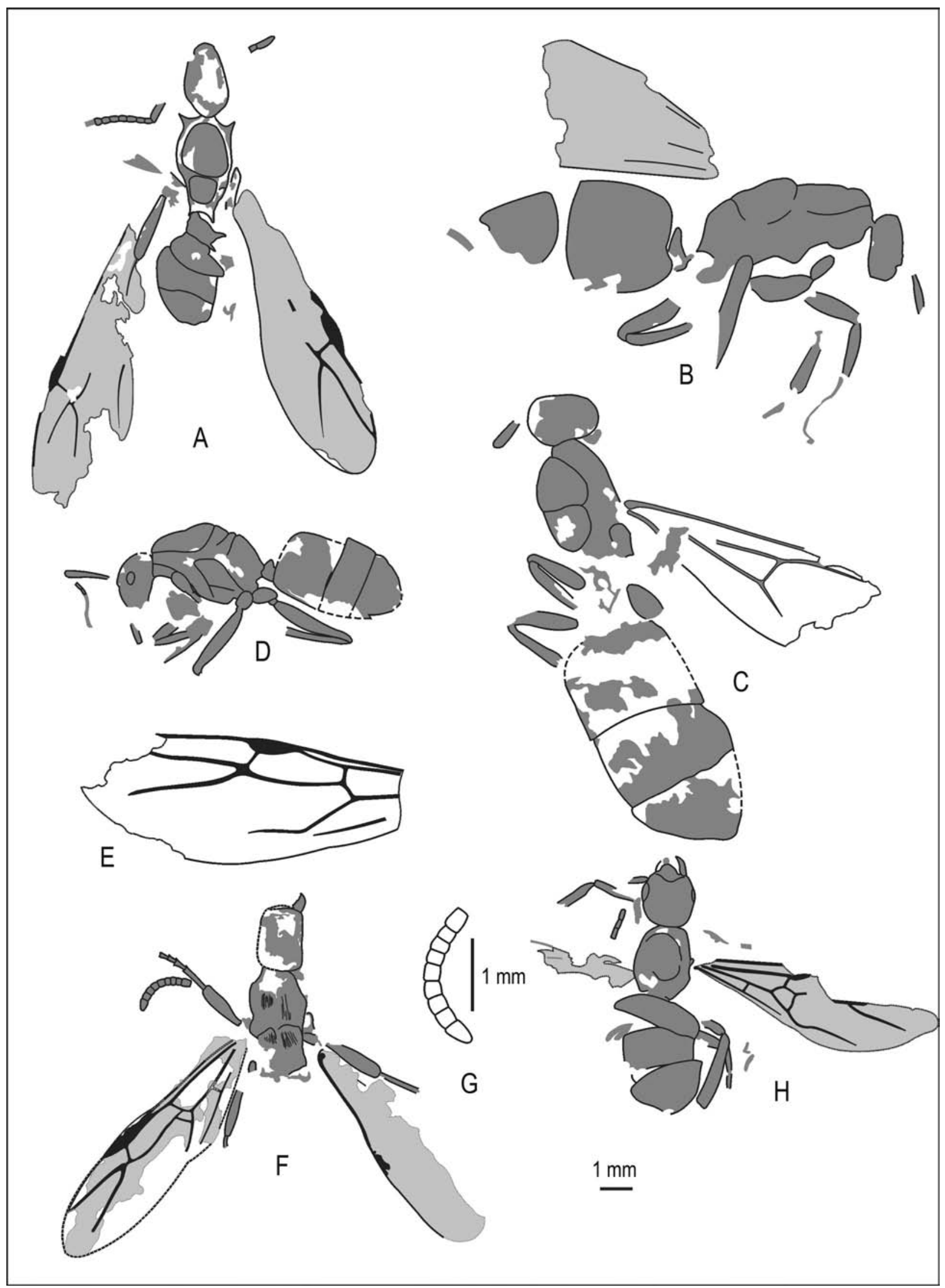

Fig. 4. 
elongate petiole is clearly visible, or only fragments of chitin have been preserved in place of the waist. Moreover, the first gastral segment of these specimens is only slightly bigger than the second segment, giving evidence that the waist of these ants was one-segmented. In Myrmicinae, the first gastral segment is always considerably longer than any of the following gastral segments. In our opinion, these ants are males of Oecophylla obesa (HEER) (see below).

MAYR (1867) examined three specimens identified by HEER as Attopsis anthracina and four specimens identified by HeEr as A. nigra. Among the latter, he found two gyne Myrmicinae with a wide body, rugose sculpture of the dorsal surface of the mesosoma and petiole, and granulate sculpture of the gaster. The wing venation of these ants had not been preserved. Assuming that the venation was as specified by HeEr in the description of the genus Attopsis, MAYR concluded that these ants had to be placed in the genus Cataulacus F. Sмiтн. We have not found within the studied collections any specimens complying with MAYR's descriptions. Since those specimens were doubtlessly not types, and since, according to HeER's description, members of the genus Attopsis have an elongate mesosoma, these specimens should be placed in other genera.

\section{Attopsis longipennis HeER, 1849 Figs. 4A, 17A}

1849 Attopsis longipennis HeER, p. 155, pl. 12, fig. 11 (). 1893 Attopsis longipennis Heer, 1849. - Dalla Torre, p. 139.

1907 Attopsis longipennis Heer, 1849. - Handlirsch, p. 877.

1911 Attopsis longipennis HeER, 1849. - WhEeler, p. 159.

1995 Attopsis longipennis HeER, 1849. - Bolton, p. 77.

2003 Attopsis longipennis HeER, 1849. - Bolton, p. 258.

Studied material: Lectotype UMJG\&P no. 210 962, gyne figured by HeER (1849: pl. 12, fig. 11).

Description: Gyne. Body length $8.8 \mathrm{~mm}$. Head oval, elongate, 1.3 times as long as wide. Occipital margin rounded, occipital angles absent. Scape protruding beyond occipital margin of head. Preserved joints of funiculus longer than wide. Mesosoma slightly wider than head, 1.75 times as long as wide. Pronotum with pair of short straight denticles. Scutum relatively small, not overhanging pronotum, slightly longer than wide and twice as long as scutellum. Parapsidal furrows absent. Petiole massive, with pair of slightly curved denticles. Forewings narrow and long. Right wing clearly showing closed cell 3r; vein sections $5 \mathrm{RS}$ and $4 \mathrm{M}$ with joint start (cross-vein rs-m absent), indicating absence of closed cell rm. HeER's figure shows that closed cell mcu is absent, but actually the area where the cross-vein m-cu (that could close this cell) should have been was not preserved in this specimen.

Measurements of lectotype, in mm: $\mathrm{AL}=3.2, \mathrm{AW}=1.8$, $\mathrm{HL}=2.5, \mathrm{HW}=1.5, \mathrm{FWL} \sim 11$.

Remarks: HeER described this species from two specimens, one of them (UMJG\&P no. 210 962) was figured (1849: pl. 12 , fig. 11), and has been preserved, and we designate it as the lectotype.

\section{Genus Camponotus MAYr, 1861}

Type species: Formica ligniperda LATREILle, 1802, by subsequent designation of BINGHAM (1903).

Diagnosis (for compression fossils): Waist consisting of one segment (petiole); gaster without constriction between first and second gastral (III and IV abdominal) segments. Antennae geniculate in both sexes, 12-segmented in gynes and workers, and 13-segmented in males. Scape attached at some distance from clypeus. Mesosoma and petiole nondentate. First gastral segment slightly longer than second. Petiole with scale. Forewing with closed cells $1+2$ r, 3r, and without closed rm and mcu; sections 5RS and 4M with joint start (cross-vein rs-m absent).

Species numbers and distribution: 1095 living species and 491 subspecies distributed worldwide. 34 fossil species were described from Late Eocene, Oligocene and Miocene deposits of Europe, Asia and North America (www.antweb. org, accessed 7 March 2014).

\section{Camponotus induratus (HeER, 1849)}

Figs. 4B-E, 17D

1849 Formica indurata HeER, p. 116, pl. 11, fig. 2 (described as $\sigma^{7}$ ).

1849 Formica pinguicola radobojana MAYR, 1867. HeEr, p. 118, pl. 9, fig. b, g; pl. 11, figs. 14h, 15c (ơ), n. syn.

1867 Formica indurata HeER, 1849. - HeER, p. 9, pl. 1, fig. $6 \mathrm{a}, \mathrm{b}$.

1867 Formica pinguicola HeER, 1849. - HeER, p. 10, pl. 1, fig. 8 , n. syn.

Fig. 4. Species of the subfamily Formicinae. A - Attopsis longipennis HeER, 1849, lectotype UMJG\&P no. 210962 (O); B-E - Camponotus induratus (HeER, 1849). B - Holotype of Formica indurata HeER, 1849 UMJG\&P no. 77.632, (9); C - specimen NHMW no. 1852.XXIX.4 determined by HeER as Formica indurata, studied by MAYR (\$); D - lectotype of Formica pinguicola radobojana HeER, 1849, UMJG\&P no. 77.644c (o'); E - paralectotype of $F$. pinguicola radobojana UMJG\&P no. 77.645i (forewing); F-G - Gesomyrmex bremii (HeER, 1849): F - lectotype of Myrmica bremii HeER, 1849, UMJG\&P no. 77.482 (9); $\mathrm{G}$ - funiculus of the same specimen; H - Heeridris croaticus sp. nov., holotype NHMW no. $1852 . I .999$ (9). 
1867 Camponotus induratus (HeER, 1849). - MAYr, p. 52.

1867 Camponotus pinguiculus (HEER, 1849). - MAYR, p. 52, n. syn.

1907 Camponotus pinguiculus radobojanus (HeER, 1849). - HaNDLIRSCH, p. 867, n. syn.

1907 Camponotus induratus (HeER, 1849). - HandLIRSCH, p. 868.

1995 Camponotus induratus (HeER, 1849). - Bolton, p. 105.

1995 Camponotus pinguiculus (HeER, 1849). - Bolton, 117, n. syn.

Studied types: Holotype of Formica indurata UMJG\&P no. 77.632, (\$, figured in pl. 11, fig. 2, HeER, 1849). Lectotype (designated here) of Formica pinguicola radobojana UMJG\&P no. 77.644c (o', figured in pl. 11, fig. 15 c). Paralectotypes of $F$. pinguicola radobojana UMJG\&P nos. 77.645h (sex unknown, figured in HEER 1849, pl. 11, fig. 14h), 77.645i (wing, figured HeER 1849, pl. 11, fig. 14i), $77.646 \mathrm{~b}$ (o', figured in HeER 1849, pl. 10, fig. 9b), 77.646g (sex unknown, figured in HeER 1849, pl. 10, fig. 9g).

Other studied material: GBA: 2009/016/0149(). NHMW: 1852.XXIX.4 (\%, specimen studied by MAYR), 1865.X.1121 $\left(\bigcirc^{7}\right)$, specimen without number (\%).

Diagnosis: All known Miocene species of Camponotus (only gynes) were described from Shanwang (China) (ZhANG 1989). C. induratus differs from them in the combination of its size and angulate propodeum.

Description: Gyne. BL 13.5-17 mm. Head longer than wide, with parallel sides, rounded occipital angles and weakly concave occipital margin. Eye oval. Scape extending beyond posterior corner of head. Second and third joints of funiculus nearly twice as long as wide. Mesosoma 1.752.1 times as long as high. Scutum longer than scutellum, not overhanging pronotum. Propodeum angular in side view, with dorsum and declivity forming rounded obtuse angle; propodeal dorsum shorter than declivity. Petiole with high scale. Gaster oval. Forewing as in genus diagnosis; cell $1+2 \mathrm{r}$ twice as long as wide; section $1 \mathrm{M}$ longer than $1 \mathrm{RS}$.

Male. BL ca. $10 \mathrm{~mm}$. Eye oval, situated slightly behind midlength of head, making gena twice as long as maximum eye diameter. Scape extending beyond posterior corner of head, nearly as long as head. Second and third joints of funiculus nearly three times as long as wide. Mesosoma nearly 1.5 times as long as high. Propodeum gradually rounded in side view. Legs rather long. Petiole triangular in side view. Gaster oviform in side view.

Measurements, in mm: Gynes: UMJG\&P no.77.632 (holotype): $\mathrm{AL}=5.3, \mathrm{HL}=2.3$; GBA no. 2009/016/0149: $\mathrm{AL}=5.6$, $\mathrm{HL}=2.5$; NHMW no. 1852.XXIX.4: $\mathrm{BL}=15.2, \mathrm{AL}=5.0$, $\mathrm{ScL}=1.6$, SctL=1.4; NHMW without number: $\mathrm{BL}=14.3$, $\mathrm{AL}=4.8, \mathrm{HL}=2.8, \mathrm{HW}=2.3$. Males: $\mathrm{UMJG} \& \mathrm{P}$ no. $77.644 \mathrm{c}$ : $\mathrm{BL}=9.9, \mathrm{AL}=3.6, \mathrm{HL}$ 1.9, $\mathrm{ED}=0.4, \mathrm{~F} 2 \mathrm{~L}=2.3, \mathrm{~F} 3 \mathrm{~L}=2.6$; UMJG\&P no. $77.646 b: A L=3.8$.

Remarks: MAYR (1867) examined two specimens identified by HeER as Formica indurata (including NHMW no. 1852.
XXIX.4), and identified them as gynes of Camponotus. At the same time, he doubted that the holotype figured by HEER (1849: pl. 11, fig. 2) and described by HeER as male was actually an ant. However, his doubts are explained by the poor quality of the figure. We have studied the holotype and come to the conclusion that it belongs to the same species of Camponotus, but it is a gyne, not a male, as HeEr believed. MAYR (1867) also studied one specimen identified by HeER as Formica pinguicola radobojana and identified it as a male Camponotus. We have examined five syntypes of $F$. pinguicola radobojana stored in UMJG\&P: specimens UMJG\&P nos. 77.644c and 77.646b are doubtlessly males of Camponotus; the forewing UMJG\&P no. $77.645 \mathrm{i}$ is also a typical Camponotus wing; specimens UMJG\&P nos. $77.645 \mathrm{~h}$ and $77.646 \mathrm{~g}$, labelled as syntypes, are poorly preserved, and we identified them as Formicidae incertae sedis. Therefore, we fully agree with MAYR that $F$. indurata and $F$. pinguicola radobojana are actually gynes and males of Camponotus. Furthermore, in our opinion, they are gynes and males of the same species, and there is no reason to consider them two different species. $F$. pinguicola was originally described from Oeningen, not from Radoboj, and the actual taxonomic status of $F$. pinguicola oeningensis remains unknown.

\section{Genus Gesomyrmex MAYR, 1868}

Type species: Gesomyrmex hoernesi MAYR, 1868, by monotypy.

Diagnosis (for compression fossils): Gyne. Waist consisting of one segment (petiole); gaster without constriction between first and second gastral (III and IV abdominal) segments. Head longer than wide. Antennae geniculate, 10-segmented, with short scape. Mandible with 5-10 acute teeth. Posterolateral corners of the head and propodeum without spines. Metacoxae closely approximated. Forewings with closed cells $1+2 \mathrm{r}, 3 \mathrm{r}$ and mcu; vein sections $5 \mathrm{RS}$ and $4 \mathrm{M}$ with joint start (cross-vein rs-m absent).

Species numbers and distribution: Six extant species are known, which are distributed in the Oriental tropics. Five fossil species are known from the Middle Eocene of Germany (Messel, Eckfeld) and one from Late Eocene European ambers (DLUSSKY et al. 2009).

\section{Gesomyrmex bremii (HeER, 1849), n. comb.} Figs. 4F-G, 17F

1849 Myrmica bremii Heer, p. 161, pl. 13, fig. 5 (ơ). 1907 Myrmica bremii Heer, 1849. - Handlirsch, p. 875. 1995 Myrmica bremii Heer, 1849. - Bolton, p. 277.

Studied material: Lectotype (designated here), UMJG\&P no. 77.482, ventral imprint of gyne without petiole and gaster.

Diagnosis: The anterior clypeal margin is as in Gesomyrmex 
flavescens Dlussky, WAPPLER \& Wedmann, 2009 (other fossil species have anterior margin projected as rounded lobe), but the head is longer than in G. flavescens (1.2 times as long as wide in G. flavescens and 1.4 times in G. bremii).

Description: Gyne. Judging by the preserved parts, BL ca. $9 \mathrm{~mm}$. Head subrectangular, 1.4 times as long as wide. Anterior clypeal margin weakly convex. Completely preserved funiculus 9-segmented. Scape, although displaced, obviously shorter than head. Mandible triangular with seven teeth. Mesosoma elongate, twice as long as wide. Mesosomal sternites weakly striated. Petiole and gaster not preserved. Forewing long and narrow, with closed cells $1+2 \mathrm{r}$, 3r and mcu; cell mcu small, trapezoid; vein sections 5RS and 4M partly united and forming short vein section RS+M.

Measurements of lectotype, in $\mathbf{m m}: \mathrm{AL}=3.6, \mathrm{AW}=1.8$, $\mathrm{HL}=2.0, \mathrm{HW}=1.4, \mathrm{FWL}=9.3$.

Remarks: A single syntype of Myrmica bremii has been preserved, and is designated here as the lectotype. The petiole of this specimen has not been preserved, but the combination of characters (head shape, 10-segmented antennae, forewing venation) gives evidence that the species belongs to the genus Gesomyrmex. HeER's (1849, pl. 13, fig. 5) figure shows another specimen, in which the head has not been preserved. HeER depicted a two-segmented waist, but juding by the position of the legs and the shape of the mesosoma, the petiolar region depicted in the figure should have been occupied by the propodeum.

\section{Genus Heeridris nov.}

\section{Type species: Heeridris croaticus $\mathrm{n}$. $\mathrm{sp}$.}

Ethymology: The genus is named for Oswald HeER in recognition of his pioneering work on the fossil ants of Radoboj.

Diagnosis: Gyne. Waist consisting of one segment (petiole) with scale; gaster without constriction between first and second gastral (III and IV abdominal) segments. Anterior margin of clypeus rounded. Posterior margin of head gradually rounded, without occipital angles. Eyes large; with head in full-face view the eyes in front of the midlength of the side of the head.. Forewing with closed cell mcu, and evidently also $1+2 \mathrm{r}$ and $3 \mathrm{r}$; free branches $5 \mathrm{RS}$ and $4 \mathrm{M}$ leaving cell $1+2 \mathrm{r}$ from common expanded point of origin. Icu $>1.45$.

Remarks: The new genus doubtlessly belongs to the subfamily Formicinae. This is evident from the one-segmented waist and from the wing venation typical of this subfamily. However, this genus has a unique combination of characters, not found in any extant or extinct genus of the subfamily. In those Formicinae that have a closed cell mcu in the forewing (Formica, Lasius, Proformica and others), the eyes are either situated at the midlength of the head or shifted backward, whereas in Heeridris, they are strongly shifted forward. The only exception known to us is $G e$ - somyrmex breviceps (Dlussky et al., 2009), in which the eyes are shifted forward, but this species has a subrectangular head with strongly pronounced occipital angles and a concave occipital margin. In the other Formicinae that have the eyes shifted forward (Plagiolepis, Nylanderia and others) a closed cell mcu in the forewing is absent.

\section{Heeridris croaticus n. sp.}

Figs. 4H, 17C

Etymology: The species name is derived from the country of origin (Croatia).

Studied material: Holotype NHMW nos. 1852.I.999 ( identified by HeER as Formica ungeri), 1852.I.1000 (counterpart of the same specimen). Paratype NHMW, without number (\$).

Description: Gyne. Body length 6-8.5 mm. Head longer than wide, with convex sides and gradually rounded occipital margin. Anterior margin of clypeus protruding as rounded lobe. Eyes large, oval, situated in front of lateral midlength of head. Gena nearly as long as maximum eye diameter. Mesosoma robust, 1.6-1.7 times as long as wide. Scutum not overhanging pronotum. Petiole with scale. Gaster oval. Forewing with closed cell mcu, and evidently also $1+2 \mathrm{r}$ and $3 \mathrm{r}$; free branches $5 \mathrm{RS}$ and $4 \mathrm{M}$ leaving cell $1+2 \mathrm{r}$ from common expanded point of origin; $4 \mathrm{M}$ faintly curved; cell mcu trapezoid. Icu=2.0.

Measurements, in mm: Holotype: $\mathrm{BL}=8.2, \mathrm{AL}=2.3$, $\mathrm{AW}=1.7, \mathrm{HL}=1.9, \mathrm{HW}=1.7, \mathrm{ED}=0.60, \mathrm{FWL}=8.0$. Paratype: $\mathrm{AL}=1.8, \mathrm{HL}=1.1, \mathrm{FWL}=6.5$.

\section{Genus Oecophylla F. Sмітн, 1860}

Type species: Formica virescens FABRICIUS, 1775, a junior synonym of Oecophylla smaragdina (FABRICIUS, 1775), by subsequent designation of Bingham (1903).

Diagnosis (for compression fossils): Waist consisting of one segment (petiole); gaster without constriction between first and second gastral (III and IV abdominal) segments. Size relatively large, head subrectangular with rounded occipital corners; antenna geniculate in both sexes. Scape attached at some distance from clypeus. Mandibles large, triangular, with sharp teeth on the masticatory margin. Petiole elongate, without scale, or nodiform (only in gynes). Forewing with closed cells $1+2 \mathrm{r}, 3 \mathrm{r}$, with no closed $\mathrm{rm}$ and $\mathrm{mcu}$; posterior margin of cell $3 r$ (formed by RS) always concave; vein sections 5RS and 4M with joint start (cross-vein rs-m absent).

Species numbers and distribution: Two extant species of Oecophylla are known. O. longinoda (LATReille, 1802) is widespread in the forested regions of tropical Africa, and O. smaragdina (FABRICIUS, 1775) ranges from India across almost all of tropical Asia to the Solomon Islands and 
northern Australia. Nine fossil species are known from the Eocene, Oligocene and Miocene deposits of Europe, with one species known from the Miocene deposits of Africa (DLussky et al. 2008).

\section{Oecophylla obesa (HeER, 1849) Figs. 5A-F, 18A-B, E}

1849 Formica obesa HeER, p. 108, pl. 8, fig. 1 (우).

1849 Formica pinguis HeER, p. 110, pl. 8, figs. 3, 9a (), n. syn.

1849 Attopsis anthracina HeER, p. 156, pl. 12, fig. 12 (o'), n. syn.

1849 Attopsis nigra HeER, p. 157, pl. 12, fig. 13 (क), n. syn.

1867 Attopsis longipes HeER, p. 29, pl. 2, fig. 15 (o'?), n. syn.

1867 Oecophylla obesa (HeEr, 1849). - MAYr, p. 50.

1867 Camponotus pinguis (HeER, 1849). - MAYr, p. 51, n. syn.

1867 Cataulacus anthracinus (HEER, 1849). - MAYR, p. 58 , n. syn.

1893 Cataulacus anthracinus (HeER, 1849). - DALlA TORRE, p. 137, n. syn.

1907 Oecophylla obesa (HeEr, 1849). - HANDLIRsch, p. 860.

1907 Camponotus pinguis (HeER, 1849). - HandLIRSCH, p. 867, n. syn.

1907 Cataulacus niger (Heer, 1849). - Handlirsch, p. 876, n. syn.

1907 Cataulacus anthracinus (HEER, 1849). - HANDLIRSCH, p. 878, n. syn.

1907 Attopsis longipes (HeER, 1867). - Handlirsch, p. 878 , n. syn.

1995 Attopsis longipes (HeER, 1867). - Bolton, p. 77, n. syn.

1995 Camponotus pinguis (HeER, 1849). - Bolton, p. 117, n. syn.

1995 Cataulacus anthracinus (Heer, 1849). - Bolton, p. 137, n. syn.

1995 Oecophylla obesa (HeEr, 1849). - Bolton, p. 298.

Studied types: Lectotype of Formica obesa UMJG\&P no. 77.625 (designated here, \&, figured in HeER, 1849, pl. 8, fig. 1b). Paralectotype of Formica obesa UMJG\&P no. 77.546 ( + , figured in HeER, 1849, pl. 8, fig. 1b). Lectotype of Formica pinguis radobojana UMJG\&P no. $77.646 \mathrm{a}$ (designated here, + , figured in HEER, 1849, pl. 10, fig. 646a). Neotype of Attopsis anthracina GBA no. 2009/016/0634 (designated here, $\mathrm{o}^{7}$ ). Neotype of Attopsis nigra: GBA no.
2009/016/0118 (designated here, ơ). Lectotype of Attopsis longipes UMJG\&P no. 77.561 (designated here, ơ).

Other studied material: GBA: 2009/016/0109 (\%), 2009/016/0136 (ơ), 2009/016/0306 (wing), 2009/016/0370 (P), 2009/016/0420 (ơ), 2009/016/0430 (P), 2009/016/0577 (ᄋ). UMJG\&P: 77.484 (wing), 77.554 (? $\left.\sigma^{7}\right), 77.583$ (wing), $77.629\left(\sigma^{7}\right), 77.633\left(\sigma^{7}\right), 77.636\left(\sigma^{7}\right)$. NHMW: 1852.I.1001 (\%), 1852.XXIX.3 (wing), 1852.XXIX.38 (ơ), PSWH Coll. 2001a $\left(0^{7}\right)$.

Diagnosis: Head of $O$. obesa gynes is wider than long and petiole is wider than long, as in both extant species and in the fossil O. superba ThÉoBald, 1937 (Kleinkems, Germany; Oligocene), but the scutum of gynes in these species is distinctly wider than long, whereas in O. obesa the scutum is nearly as long as wide.

Description: Gyne. BL 15-18 mm, AL 5.2-6.5 mm, FWL 12.5-16.5 mm. Head wider than long, with weakly convex sides and rounded occipital margin. Mesosoma wider than head. Scutum nearly as long as wide, and 2.5 times as long as scutellum, overhanging pronotum in dorsal view. Scutellum wider than long. Legs rather short and thick. Petiole wider than long. Gaster oval. Wing venation typical for Oecophylla. Forewing with closed cells $1+2$ r, 3r, with no closed rm and mcu; pterostigma narrow; vein sections 5RS and 4M with joint start (rs-m lost); cell 3r narrow; 5RS bent into $3 \mathrm{r}$; $1 \mathrm{RS}$ and $1 \mathrm{M}$ form united transverse vein; $1 \mathrm{M}$ longer than 1RS or subequal to it; 1RS inclined, forming acute angle with R; 2r-rs inclined; vein section RS+M (delimiting cell $1+2 \mathrm{r}$ from below) bent.

Male. BL 6-7 mm, AL 2.5-3.5 mm, FWL 6-7 mm. Head comparatively small, narrower than mesosoma. Mesosoma twice as long as high and 2.2-2.4 times as long as wide. Legs rather long and thin. Scutum narrow, distinctly longer than wide. Petiole longer than wide and longer than high, narrowed anteriorly. Gaster oviform. Wing venation as in gyne.

Measurements, in mm: Gynes: UMJG\&P no. 77.625 (lectotype): $\mathrm{AL}=6.5, \quad \mathrm{FWL}=15.4, \mathrm{HW}=2.6 ; \quad \mathrm{UMJG} \& \mathrm{P}$ no. 77.646a: $\mathrm{AL}=5.8, \mathrm{HL}=2.1$ (2.7 including mandibles); GBA no. 2009/016/0430: $\mathrm{AL}=5.7, \mathrm{FWL}=16.4$, HL (including mandibles)=2.6; GBA no. 2009/016/0577: $\mathrm{AL}=5.2$, $\mathrm{HL}=2.0$ (2.6 including mandibles), $\mathrm{HW}=2.3$; NHMW no. 1852.I.1001: $\mathrm{AL}=6.0, \mathrm{FWL}=12.5, \mathrm{HW}=2.4$. Males: $\mathrm{AL} 2.4$ 3.3 (average 3.0, $\mathrm{n}=7$ ), FWL 6.3-7.9 (average 7.5, $\mathrm{n}=9$ ).

Remarks: Formica obesa was described from four specimens, three of which are stored in UMJG\&P. We designate as lectotype the imprint of a gyne, 77.625, figured by HEER

Fig. 5. Oecophylla obesa (HeER, 1849). A - lectotype of Formica obesa radobojana UMJG\&P no. 77.625 (\$); B - lectotype of Formica pinguis radobojana HeER, 1849, UMJG\&P no. 77.646a (\$); C - neotype of Attopsis anthracina HeER, 1849,

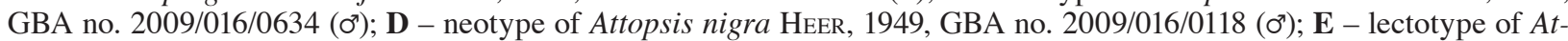
topsis longipes HeER, 1867, UMJG\&P no. 77.561 (o'); F - forewing GBA no. 2009/016/0306. 


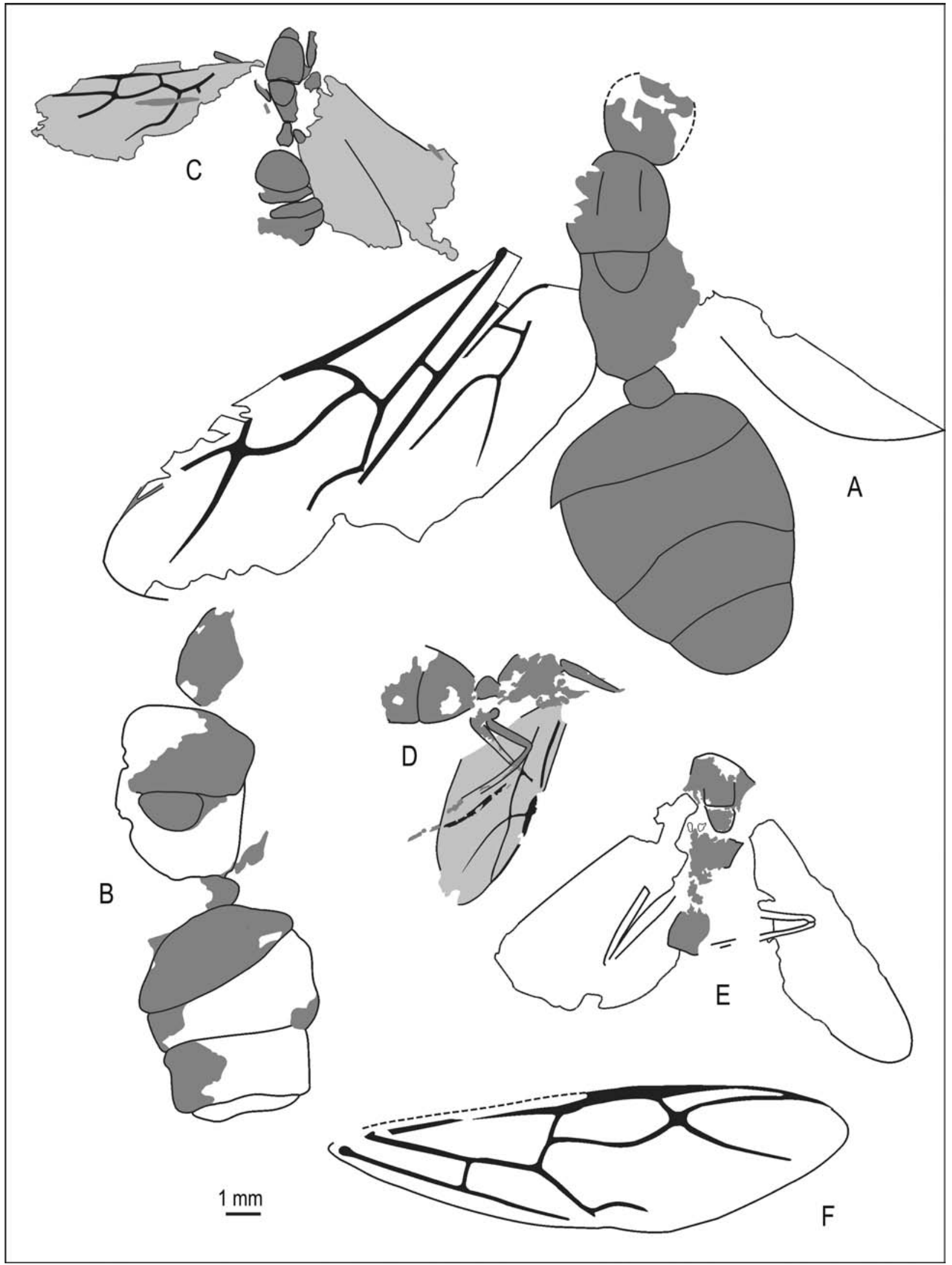

Fig. 5. 
(1849: pl. 8, fig. 1b). MAYR (1867), having studied specimens identified by HeER, placed them in the genus Oecophylla. We have examined the syntypes and have come to the same conclusion.

Formica pinguis was described from three specimens stored in UMJG\&P. We designate as lectotype the imprint of the gyne figured by HEER (1849: pl. 10, fig. 646a). MAYR (1867) examined one specimen identified by HEER, and identified it as belonging to Camponotus, but this specimen was not a syntype. The syntypes doublessly belong to the genus Oecophylla. HeEr wrote that $F$. pinguis was very similar to $F$. obesa and differs from it in coloration. We could not find any differences between these species except in coloration. Since the coloration of fossil imprints depends on the specifics of fossilization and cannot be used as a diagnostic character, we believe that $F$. pinguis is a junior synonym of $F$. obesa.

Attopsis antracina and A. nigra were described from a single specimen each; neither of these specimens has been preserved. According to HEER's descriptions, the former species was described from a male, and the latter from a gyne, possibly conspecific. However, judging by HeER's figure, the proportions of the holotype of $A$. nigra (shape of the mesosoma, relative wing length) give evidence that it is male. Specimens stored in UMJG\&P and listed in the catalogue as syntypes of these species differ from HeER's figures and cannot be considered syntypes. We designate as neotypes the best-preserved specimens most similar to HEER's figures: GBA no. 2009/016/0634 (A. anthracina) and GBA no. 2009/016/0118 (A. nigra). We found no differences between these species. MAYR (1867) examined three specimens identified by HEER as Attopsis anthracina and four specimens identified by HEER as A. nigra. Among the latter four, MAYR found two Myrmicinae gynes with wide bodies, rugose dorsal sculpture of the surfaces of the mesosoma and petiole, and granulate sculpture of the gaster. The wing venation of these ants has not been preserved. Assuming that the venation was as characterized by HEER in the description of the genus Attopsis, MAYR concluded that the ants had to be placed in the genus Cataulacus F. Smith, 1854. We have failed to find in the studied collections any specimens complying with MAYR's description. Since these specimens were doublessly not types, MAYR's synonymization cannot be considered valid. We have examined seven specimens indentified by HEER as A. anthracina and six specimens identified by HEER as A. nigra. Only two of them have two-segmented waists, but their wing venation differs from that described by HeER. We place these specimens in the genus Paraphaenogaster. In the other specimens, either a one-segmented waist with an elongate petiole is clearly visible, or only fragments of chitin have been preserved in place of the waist. Furthermore, the first gastral segment of these specimens is only slightly larger than the second, giving evidence of a one-segmented waist. In Myrmicinae the first gastral segment is always considerably longer than the following segments. HEER probably erroneously interpreted the long petiole as a two-segmented waist. The combination of the peculiar wing venation and elongate petiole give evidence that these ants belong to the genus Oecophylla.

HeER described Attopsis longipes from two specimens. Only specimen UMJG\&P no. 77.561 has been preserved, which differs from HeER's figure and is listed in the catologue as the holotype. However, it cannot be considered the holotype, and we designate it as lectotype. Judging by the description, this species should differ from the other species of the genus in the longer legs. However, the relative length of the legs in the lectotype of this species is the same as in the neotype of A. nigra. The specimen is poorly preserved, but judging by the visible characters (shape of the scutumn and scutellum, relative wing length), it is no different from A. nigra, and the two species can be synonymized.

In recent and fossil members of the genus known from both males and gynes, gynes are 1.5-2 times as large as males. The size ratio between gynes and males of Oecophylla from Radoboj is approximately the same. Since it is unlikely that gynes and males from the same deposit belonged to different species, we believe that the specimens described as Attopsis antracina, A. nigra and A. longipes are males of Oecophylla obesa.

\section{Genus Formica Linnaeus, 1758}

Type species: Formica rufa Linnaeus, 1758; by subsequent designation by CurTis 1839: 752.

Diagnosis (for compression fossils): Gyne. Waist consisting of one segment (petiole) with scale; gaster without constriction between first and second gastral (III and IV abdominal) segments. Head usually longer than wide, with rounded occipital angles. Anterior margin of clypeus rounded or angulate. With head in full-face view the eyes distinctly behind the midlength of the side of the head; gena much longer than maximum eye diameter. Mandibles triangular, dentate. Antennae 12-segmented; scape protruding beyond posterior margin of head. Second to fifth joints of funiculus 1.5-2 times as long as wide. Antennal insertion near posterior margin of clypeus. Hind coxae closely set. Forewing with closed cells $1+2 \mathrm{r}, 3 \mathrm{r}$ and mcu; free branches $5 \mathrm{RS}$ and $4 \mathrm{M}$ leaving cell $1+2 \mathrm{r}$ from common expanded origin; $5 \mathrm{RS}$ and $4 \mathrm{M}$ curved approximately equally; section 2-3RS often Sshaped. Icu>1.45. Male and gyne size subequal. Gaster oval.

Species numbers and distribution: A total of 175 extant valid species and 25 subspecies of Formica distributed in the Palearctic and Nearctic are known to date (www.antweb.org, accessed 7 March 2014). BolTon's catalogue also included a checklist of 72 extinct species, but he failed to take into account that ten of them had already been synonymised earlier (DLUSSKY 2008a), so that a total of 61 extinct species are included in the genus currently. Nine of them were described from Late Eocene ambers of Europe (DLuSSKy 2008a), eleven from Oligocene deposits of Europe (NovÁx 1877; Meunier 1915, 1917, 1923; ThÉobald 1837), three from Oligocene deposits of the United States (CARPENTER 1930), four from Miocene deposits of China (ZHANG 1989), and 37 from Miocene deposits of Europe, including 30 from Oeningen and Radoboj (HeER 1849, 1867). However, this number is clearly overestimated, and following modern revisions the assemblages of the Oligocene and Miocene will doubtlessly comprise fewer species. For instance, in 

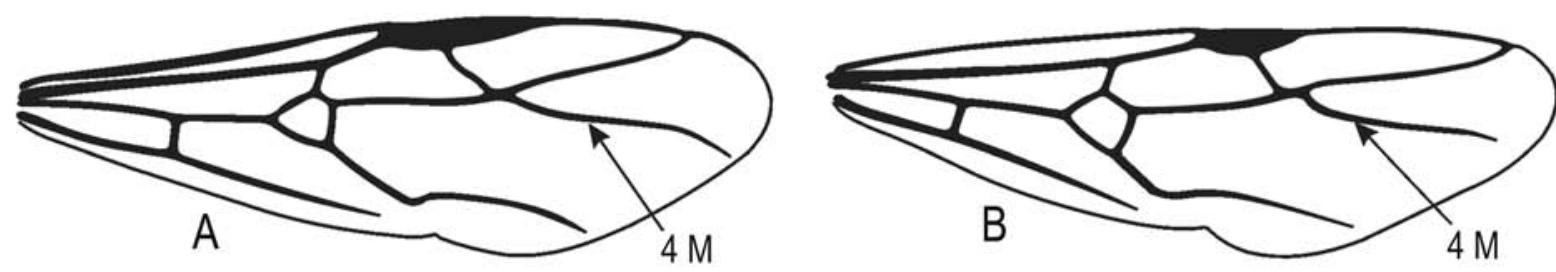

Fig. 6. Forewing venation of Recent Formica rufa (A) and Lasius niger (B).

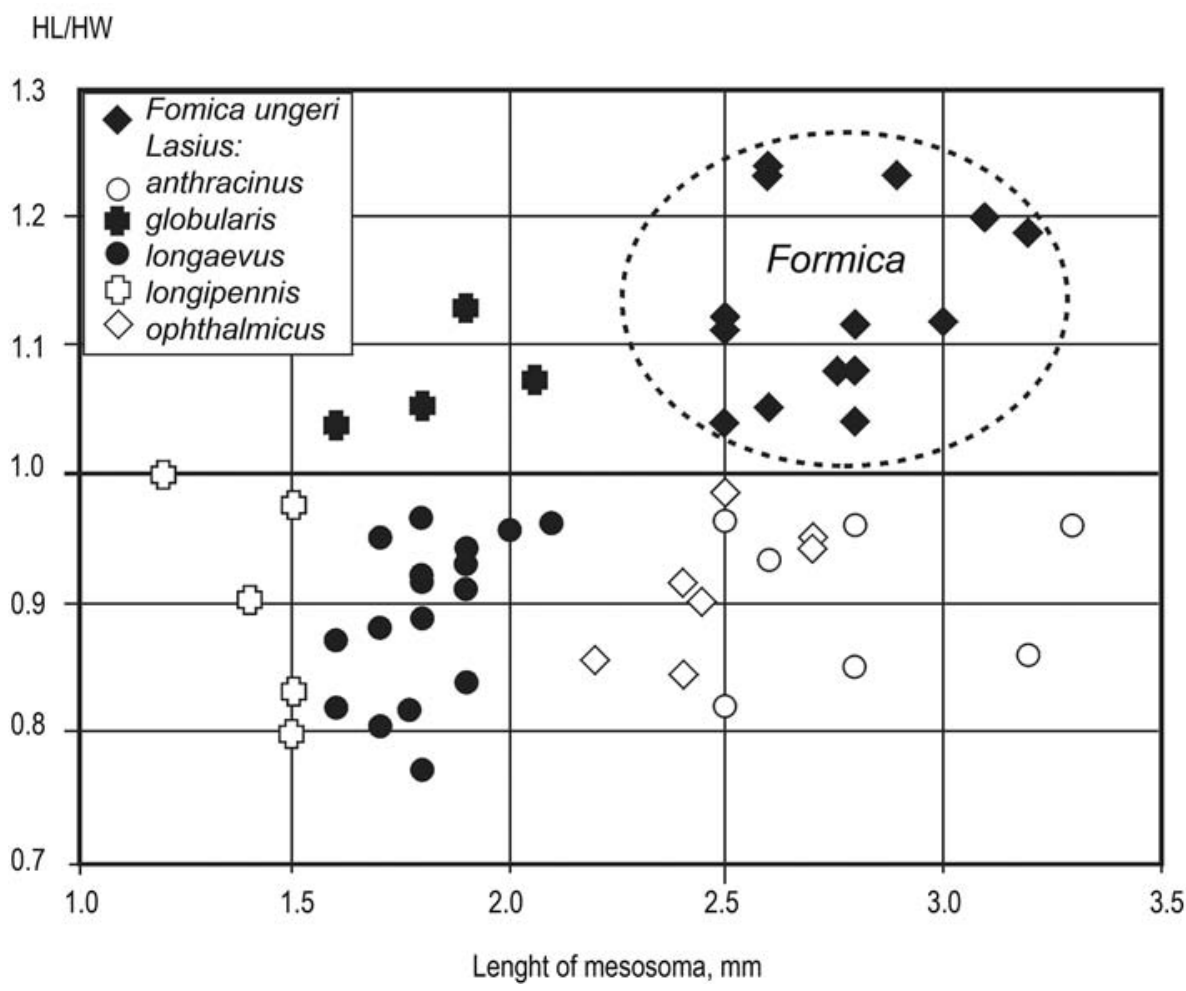

Fig. 7. Relationship between mesosoma length and proportion of head (HL/HW) of gynes of Formica and Lasius from Radoboj.

this study almost all species of Formica from Radoboj are either synonymised or transferred to other genera. A total of three species are currently known from Radoboj, two of them described by HEER and one described here as new.

Up to the present, the oldest record of Formica was from the Late Eocene: Baltic amber and compression fossil Bagshot Beds, Great Britain (where Formica heteroptera CocKERELL, 1920 was described based on a forewing). However, according to our unpublished data, compression fossils belonging to this genus are present in the deposits of Messel and Eckfeld, Germany, dating to the Middle Eocene.

Remarks: Members of the genera Formica and Lasius make up $72 \%$ of all compression fossils identified to genus.
The division of this set into genera and species was the most difficult part of our work in this revision. The imprints are so poorly preserved that genera can be safely distinguished only by the wing venation (particularly the shape of vein section 4M) (Fig. 6), position of the hind coxae, and the proportions of the joints of the funiculus. But even these characters have been preserved only in some of the specimens. Only two specimens could be reliably identified: the holotype of Formica obscura HeER, and the specimen described below as $F$. parexsecta. We identified the other specimens to species based upon biometric characters. Analysis of the whole set of gynes has shown that two large groups can be recognized (Fig. 7). Members of the first group have the head wider than long and mesosoma relatively wide. All 


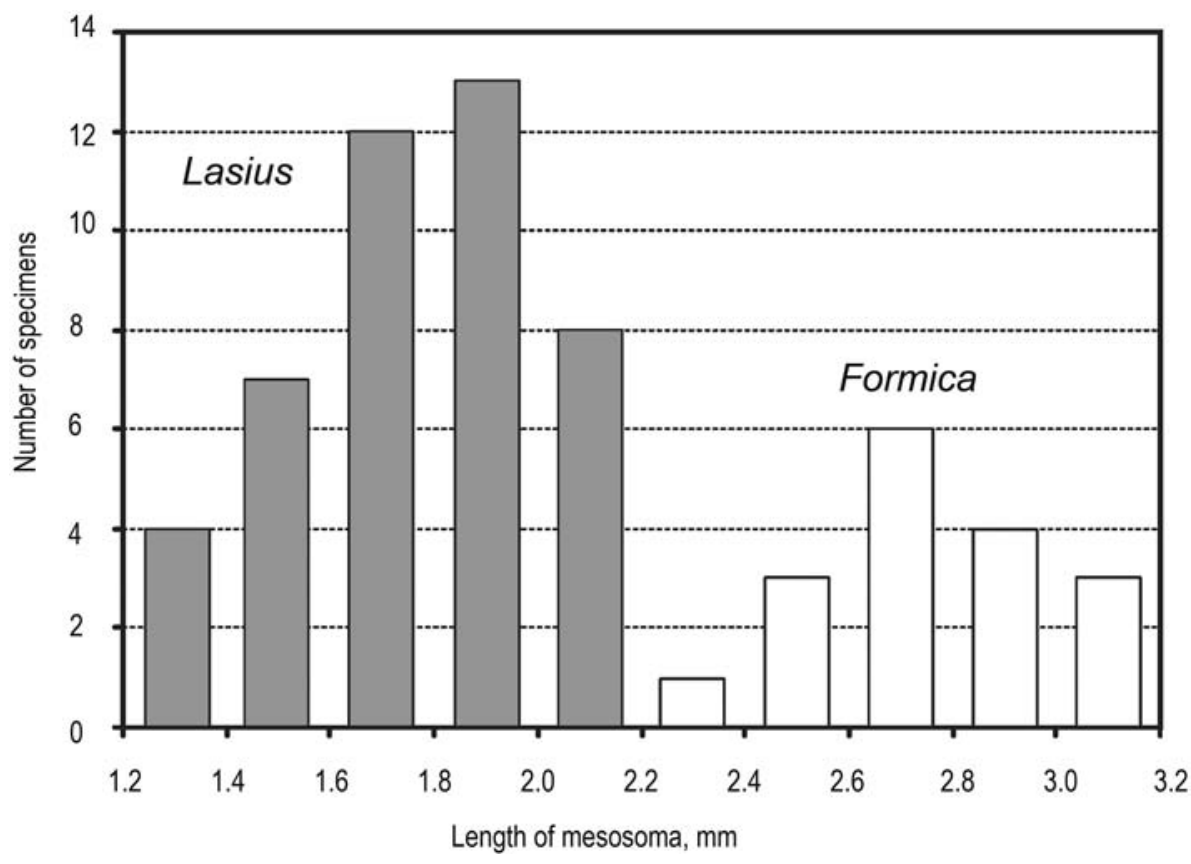

Fig. 8. Frequency distributions of mesosoma length classes among males of Formica and Lasius from Radoboj.

specimens that have wing venation or antennal funiculus preserved, or hind coxae visible, display characters of the genus Lasius. Further division of this group into species will be expounded below. In members of the second group the head is longer than wide and the mesosoma relatively narrow. This group can be divided into two subgroups: smaller individuals $(\mathrm{AL}=1.5-2.1 \mathrm{~mm})$ and larger individuals $(\mathrm{AL}=2.3-3.3 \mathrm{~mm})$ (Fig. 8). We provisionally placed the smaller individuals in the genus Lasius. The larger individuals that have the wing venation or antennal funiculus preserved display characters of the genus Formica. In addition, they have relatively short wings, which are also typical of gynes of the genus Formica. Further division of this group proved impossible, and therefore we placed it in one species, Formica ungeri. The set of males can be clearly divided by size into two groups separated by a hiatus: smaller $(\mathrm{AL}=1.2-$ $2.1 \mathrm{~mm}$ ) and larger $(\mathrm{AL}=2.3-3.1 \mathrm{~mm})$. All the larger individuals that have wing venation preserved display characters of Formica, and all the smaller ones display characters of Lasius. We have failed to find characters by which males of Formica could be divided into species, and therefore placed them all in the same species.

\section{Formica ungeri HeER, 1849} Fig. 9A-F

1849 Formica ungeri Heer, p. 128, pl. 10, fig.1b-e (\$).

1849 Formica redtenbacheri HeER, p. 129, pl. 10, fig. 2b (९), n. syn.
1849 Formica acuminata HeER, p. 142, pl. 11, figs. 13, 14g $\left(0^{\top}\right)$, n. syn.

1849 Ponera elongatula HeER, p. 150, pl. 12, fig. 7 (P), n. syn.

1867 Formica redtenbacheri HeER, 1849. - HeER, p. 13, n. syn.

1867 Formica oblita Heer, 1849. - Heer, p. 13, pl. 1, fig. 12 (\$), n. syn.

1867 Formica kollari Heer, 1849. - Heer, p. 15, pl. 1, fig. 14 (\$), n. syn.

1867 Formica aemula HeER, 1849. - Heer, p. 18, pl. 1, fig. $19\left(0^{\top}\right)$, n. syn.

1867 Poneropsis elongatula (HeER, 1849). - Heer, p. 22, n. syn.

1867 Formica ungeri HeEr, 1849. - MAYr, p. 53.

1867 Lasius redtenbacheri (HeER, 1849). - MAYr, p. 54, n. syn.

1907 Lasius redtenbacheri (Heer, 1849). - HandLirsch, p. 861, n. syn.

1907 Formica ungeri Heer, 1849. - Handlirsch, p. 862.

1907 Formica acuminata (HeER, 1849). - HandLIRSCH, p. 864 , n. syn.

1907 Formica aemula Heer, 1867. - HandliRsch, p. 864, n. syn.

1907 Formica kollari Heer, 1867. - HandliRsch, p. 864, n. syn.

1907 Formica oblita HeER, 1867. - HANDLIRSCH, p. 864, n. syn.

1907 Poneropsis elongatula (HEer, 1849). - Handlirsch, p. 880 , n. syn.

1964 Formicidae incertae generis. - TAYLOR, p. 138, n. syn. 
1995 Formica acuminata (HeER, 1849). - Bolton, p. 190, n. syn.

1995 Formica aemula Heer, 1849. - Bolton, p. 191, n. syn.

1995 Formica kollari Heer, 1867. - Bolton, p. 197, n. syn.

1995 Formica oblita Heer, 1867. - Bolton, p. 200, n. syn.

1995 Formica ungeri Heer, 1867. - Bolton, p. 205.

1995 Lasius redtenbacheri (Heer, 1849). - Bolton, p. 225, n. syn.

1995 Poneropsis elongatula (Heer, 1849). - Bolton, p. 363 , n. syn.

Studied types: Lectotype of $F$. ungeri UMJG\&P no. 77.566 (designated here, $\odot$, figured by HeER 1849, pl. 10, fig. 1c); paralectotype of $F$. ungeri UMJG\&P no. 77.548 ( $\%$, figured by HeER 1849: pl. 10, fig. 1e); lectotype of Formica redtenbacheri UMJG\&P no. 77.510 (designated here, , labelled as syntype); lectotype of Formica acuminata UMJG\&P no. 77.645g (designated here, ơ, figured by HeER 1849: pl. 10, fig. 1c); lectotype of Formica aemula UMJG\&P no. 77.519 (designated here, on, labelled as holotype); neotype of Ponera elongatula UMJG\&P no. 77.641 (designated here, P); holotype of Formica kollari UMJG\&P no. 77.574 ( $\%$, figured by Heer 1867: pl. 1, fig. 14).

Other studied material: GBA: 2009/016/0012 (P), 2009/016/0021 (\%), 2009/016/0027 (P),2009/016/0075 (○'), 2009/016/0078 (ه'), 2009/016/0106 (?), 2009/016/0143 (P), 2009/016/0161 (\%), 2009/016/0213 (\%), 2009/016/0248 (\%),

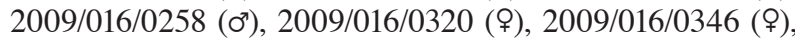
2009/016/0350 (९), 2009/016/0359 (○'), 2009/016/0361 (९), 2009/016/0365 (P), 2009/016/0371 (P), 2009/016/0450 (P),

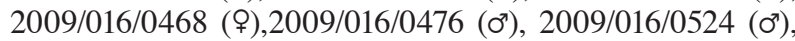
2009/016/0550 (\%), 2009/016/0552a (P), 2009/016/0557 (ठ'), 2009/016/0665 (९). UMJG\&P: 77.500 (\$), 77.502 (९), 77.509 ( $\odot$ ), 77.516 ( $\odot$, syntype of $F$. ophthalmica figured by HeER 1849: pl. 9, fig. 9b), 77.526 (\%), 77.531 (('), 77.532 (\%), 77.533

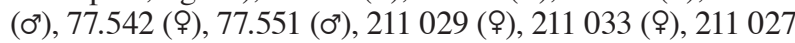

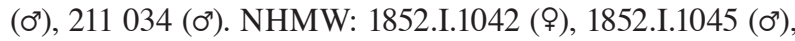

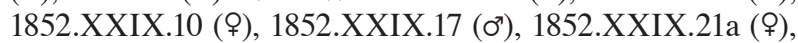

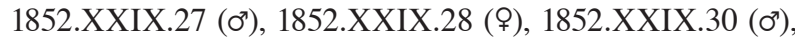
1852.XXIX.5c (\%), 1852.XXIX.6 (ช॰), D.1185 (Jahr 1884) (\%), PSWH Coll. 2001d (\%), ơ without number.

Diagnosis: Gynes of $F$. ungeri differ from the other Formicinae species from Radoboj in the following combination of characters: BL 6.1-9.8 mm, AL 2.3-3.3 mm; head longer than wide, with straight or weakly convex occipital margin; mesosoma elongate; forewing of Formica-type.

Description: Gyne. BL 6.1-9.8 mm, AL 2.3-3.3 mm, FWL 6.8-8.8 mm. Head longer than wide (HL/HW=1.04-1.23), with rounded occipital angles, and straight or weakly convex occipital margin. Anterior margin of clypeus rounded. Scape a little shorter than head (HL/SL=1.01-1.02). Second to fifth joints of funiculus nearly twice as long as wide. Mesosoma elongate, 1.8-2 times as long as wide. Legs rather long and thin. Forewings nearly as long as body (FWL/ $\mathrm{BL}=0.8-1.1$ ), and 2.3-3.3 times as long as mesosoma. Vein section 1M 1.2-1.8 (average 1.4) times as long as 1RS. Cell mcu trapezoid; vein section 1Cu 1.4-1.8 (average 1.6) times as long as RS+M.

Male. BL 6.3-9.3 mm, AL 2.3-3.1, FWL 5.2-8.3 mm. Head nearly as long as wide with rounded occipital margin. Scutum in side view weakly convex dorsally and rounded anteriorly. Dorsal and declivous parts of propodeum form rounded obtuse angle in side view; propodeal dorsum much shorter than declivous part. Forewing about as long as body (FWL/BL 0.8-1.1, average 1.0, $\mathrm{n}=6$ ) and 2.0-2.8 times (average $2.6, \mathrm{n}=10$ ) longer than mesosoma. Wing venation as in gynes.

Measurements, in mm: Lectotype UMJG\&P no. 77.566 (क): $\mathrm{BL}=8.0, \mathrm{HL}=1.8, \mathrm{FWL}=7.1$. Lectotype of $F$. acuminata (o'): $\mathrm{BL}=8.5, \mathrm{AL}=2.9, \mathrm{HL}=1.3$. Variation: Gynes: $\mathrm{BL}$ 7.2-9.8 (average 8.6, $\mathrm{n}=25$ ), AL 2.4-3.4 (average 2.8, $\mathrm{n}=23$ ), HL 1.32.1 (average1.7, $\mathrm{n}=23$ ), HW 1.2-1.8 (average 1.4, $\mathrm{n}=13$ ), FWL 7.1-9.1 (average 8.1, $\mathrm{n}=17$ ). Males: BL 6.3-9.3 (average 7.8, $\mathrm{n}=8$ ), AL 2.3-3.1 (average 2.7, $\mathrm{n}=17$ ), FWL 5.2-8.3 (average $6.8, \mathrm{n}=10)$.

Remarks: HeER described Formica ungeri from ten specimens. The collection of UMJG\&P contains nine specimens labelled as syntypes. Two of them, including specimen UMJG\&P no. 77.566, designated here as the lectotype, belong to the genus Formica, one (77.496) belongs to the genus Lasius, one (77.485) is described here as Emplastus miocenicus sp.n., and five (77.486, $77.53577 .545,77.555$ and 77.556) are poorly preserved and cannot be reliably identified to any known species. HeER distinguished this species from the other "Formica" by the shape of the gaster and pale (brown) coloration of the imprints. Neither of these characters, as mentioned above, can be used as diagnostic characters for compression fossils. MAYR (1867) examined specimens identified by HEer but not belonging to the type

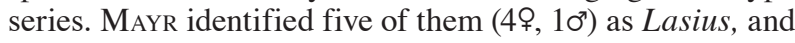
three as gynes of Formica. HandLIRSCH (1907) left this species in the genus Formica. Subsequently, this status of the species was accepted by BoLTON (1995).

Formica redtenbacheri was described from 12 gynes. The collection of UMJG\&P contains 20 specimens labelled as syntypes, but none of them complies with HeER's figures. Four of them belong to the genus Formica, four to the genus Lasius, two to the subfamily Dolichoderinae, and six are poorly preserved and cannot be reliably identified to genus. We designate here as lectotype the best-preserved specimen, UMJG\&P no. 77.510, which is similar to HeER's description and figure. MAYR (1867) examined 22 specimens identified by HeER as $F$. redtenbacheri and came to the conclusion that most of them belonged to the genus Lasius. Based on this, HaNDLIRSCH (1907) transferred this species to the genus Lasius. Subsequently, this status of the species was accepted by Bolton $(1995,2013)$. HeER mentioned in his description of this species that it was similar to $F$. ungeri and differed from it in the short, thick gaster, dark coloration and longer cell mcu. The first two characters cannot be used as diagnostic characters for compression fossils, and the shape of the cell mcu in the lectotypes of $F$. ungeri and $F$. redtenbacheri is almost identical.

Ponera elongatula was described by HeER from one specimen. In a later study, HeER (1867) transferred this spe- 


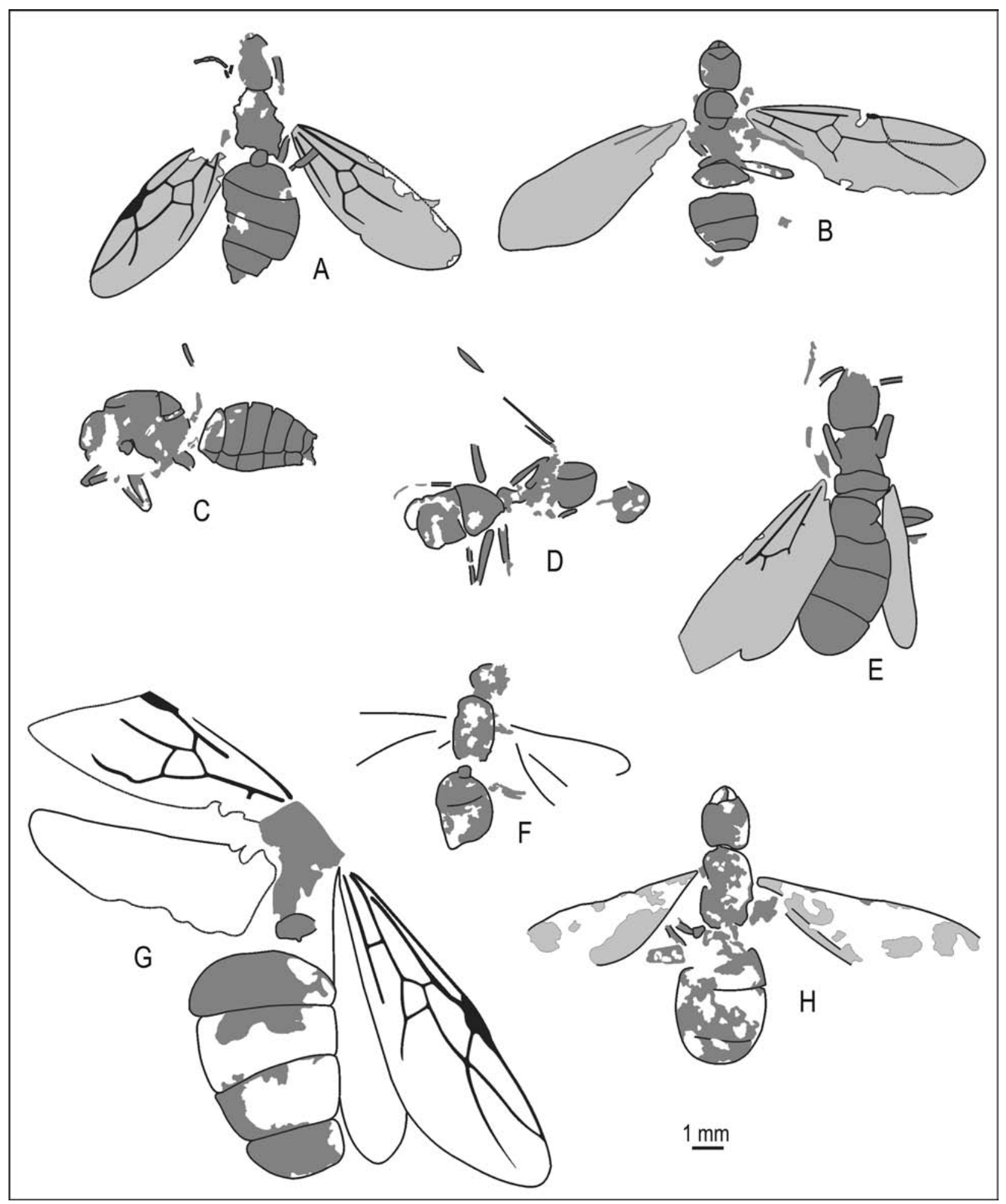

Fig. 9. Species of the genus Formica. A-F - F. ungeri HeER, 1849; A - lectotype UMJG\&P no. 77.566 (\$); B - lectotype of Formica redtenbacheri HeER, 1849, UMJG\&P no. 77.510 (\$); C - lectotype of Formica acuminata HeER, 1849, UMJG\&P

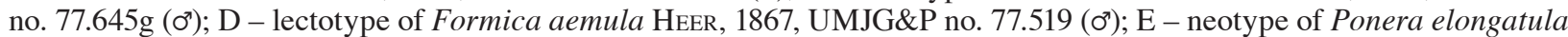
HeEr, 1949, UMJG\&P no. 77.641 (\$); F - holotype of Formica kollari HeER, 1867 UMJG\&P № 77.574 (); G - Formica obscura HeER, 1849, holotype UMJG\&P no. 77.536 (\$); H - Formica parexsecta sp. nov., holotype GBA no. 2009/016/0355 (†). 
cies to the genus Poneropsis. Mayr (1867) examined two specimens identified by HEER, which, in MAYR's opinion, did not belong to this species. However, because they were poorly preserved, he could not identify them. HANDLIRSCH (1907) left this species in the genus Poneropsis. TAYLOR (1964) considered HeER's description insufficient for placing this species in the genus Poneropsis and treated it as Formicidae incertae generis, but subsequently BOLTON (1995) reinstated the original name. The collection of UMJG\&P contains specimen no. 77.641, identified by HEER and labelled as a syntype. However, it cannot be a syntype of this species, because it does not comply with the figure of the only specimen described by HeER. We have designated it as the neotype. This specimen is outwardly similar to HeER's figure, but differs in the larger size (holotype: $\mathrm{BL}=8.2$, $\mathrm{AL}=2.2$; neotype: $\mathrm{BL}=9.2, \mathrm{AL}=2.6$ ). In both the specimen figured by HEER and the neotype, the wing venation has not been preserved and there is no constriction between the first and second gastral segments. Therefore, it is unclear why HeER placed this species within the subfamily Ponerinae. All of its visible characters safely fall within the variation range of Formica ungeri gynes.

Formica kollari was described from a single specimen, which has been preserved in UMJG\&P. HEER provided only the differences between this species and $F$. ocella and $F$. occultata. However, both these species were described from males, and belong to the genus Lasius, whereas the holotype of $F$. kollari is a gyne. Although the specimen is poorly preserved, it is no different in any visible characters (size or proportions of the head and mesosoma) from gynes of $F$. ungeri. MAYR (1867) had not seen this species, and therefore HANDLIRSCH (1907) left it in the genus Formica.

As mentioned above, we have failed to find any characters that would allow us to divide Formica males into species, and therefore placed them all, including the lectotypes of $F$. acuminata and $F$. aemula, in the same species. Judging from correlation to the extant gynes and males of the genus Formica, males of F. obscura should have been larger, and males of $F$. parexsecta (which is described below) should have had a concave occipital margin of the head. Since no such specimens had been found, we decided that all of the males found could be placed in F. ungeri.

Formica acuminata was described from two specimens. Specimen UMJG\&P no. 77.645g, figured by HEER (1849: pl. 11, figs. $13,14 \mathrm{~g}$ ), has been preserved and we designate it as the lectotype. MAYR (1867) had not seen this species, and therefore HANDLIRSCH, (1907) provisionally left it in the genus Formica.

Formica aemula was described from five specimens. According to HeER's description, this species is similar to males of $F$. redtenbacheri, and differs from them in the slightly larger size. Specimen UMJG\&P no. 77.519, labelled as holotype, has been preserved. However, it cannot be considered the holotype, because it does not match with the figure in HeER's study. We designate it here as the lectotype. This specimen is poorly preserved, but its visible characters fall within the variation range of $F$. ungeri males. MAYR (1867) saw three of the specimens identified by HEER, but they are so poorly preserved that they could not be identified to genus. Therefore, HandLIRSCH (1907) provisionally left this species in the genus Formica.
HeEr described Formica oblita from two specimens, which we have failed to find. We have also failed to find in the studied collections any other specimens identified as $F$. oblita. MAYr (1867) examined one specimen identified by HEer, but not one of the syntypes, and came to the conclusion that it is similar to other specimens identified by HEER as Formica macrocephala. Judging by HeER's description, measurements, and figure, $F$. oblita does not differ from $F$. ungeri.

F. ungeri differs from extant species of Formica in its tendency toward smaller body size. In the extant members of the subgenera Formica s. str., Serviformica and Raptiformica, body length varies from 9 to $11 \mathrm{~mm}$, while in $F$. ungeri it varies from 7.2 to $9.8 \mathrm{~mm}$ (average 8.6). However, extinct members of this genus included even smaller species: gynes of Formica flori from European ambers (Late Eocene) had a body length of 6.5-7 $\mathrm{mm}$.

\section{Formica obscura HeER, 1849}

Fig. 9G

1849 Formica obscura Heen 1849, p. 119, pl. 9, fig. 2, pl. 11 , fig. $15 \mathrm{~d}($ (P).

1867 Lasius obscurus (HEeR, 1849). - MAYR, p. 52.

1907 Lasius obscurus (HeER, 1849). - HandLIRSCH, p. 862.

1995 Lasius obscurus (HeER, 1849). - Bolton, p. 225.

Studied material: Holotype UMJG\&P no. 77.536 ( forewing, gaster and fragment of mesosoma, figured by HeER 1849: pl. 9, fig. 2).

\section{Diagnosis: Differs from $F$. ungei in its larger size.}

Description: Forewing of gyne. FWL $12.1 \mathrm{~mm}$. Cell 1+2r 3.1 times as long as wide. Cell 3r 4.9 times as long as wide. Vein section $1 \mathrm{M} 1.8$ times as long as $1 \mathrm{RS}$. Cell mcu trapezoidal; vein section $1 \mathrm{Cu}$ nearly twice as long as $\mathrm{RS}+\mathrm{M}$.

Remarks: HeER described this species from a single, partly preserved specimen. He also identified three isolated gasters found on other pieces of rock as F. obscura. We examined one of these imprints (UMJG\&P no. 77.644d), and it can belong to a gyne of any species of Formicinae similar in size. Therefore, specimen UMJG\&P no. 77.536, figured by HEER, can be considered the holotype. MAYR (1867) examined only one specimen identified by HeER as F. obscura, which proved to be a poorly preserved gyne of Lasius. Based on this, Handlirsh (1907) transferred this species to the genus Lasius. Judging by the forewing venation, the holotype of this species doubtlessly belongs to the genus Formica. Assuming that the proportions and variation of this species were the same as in extant species of this genus, and even that the holotype was the largest specimen of this species, the length of the smallest specimens had to be at least 9.9 $\mathrm{mm}$, which is outside the variation range of $F$. ungeri. Judging by their size, three specimens GBA no. 2009/016/0034 (BL=10.0, AL=3.6), GBA no. 2009/016/0043 (BL=9.9) and NHMW no. 1877.XXV.17 $(\mathrm{BL}=10.7)$ may also belong to 


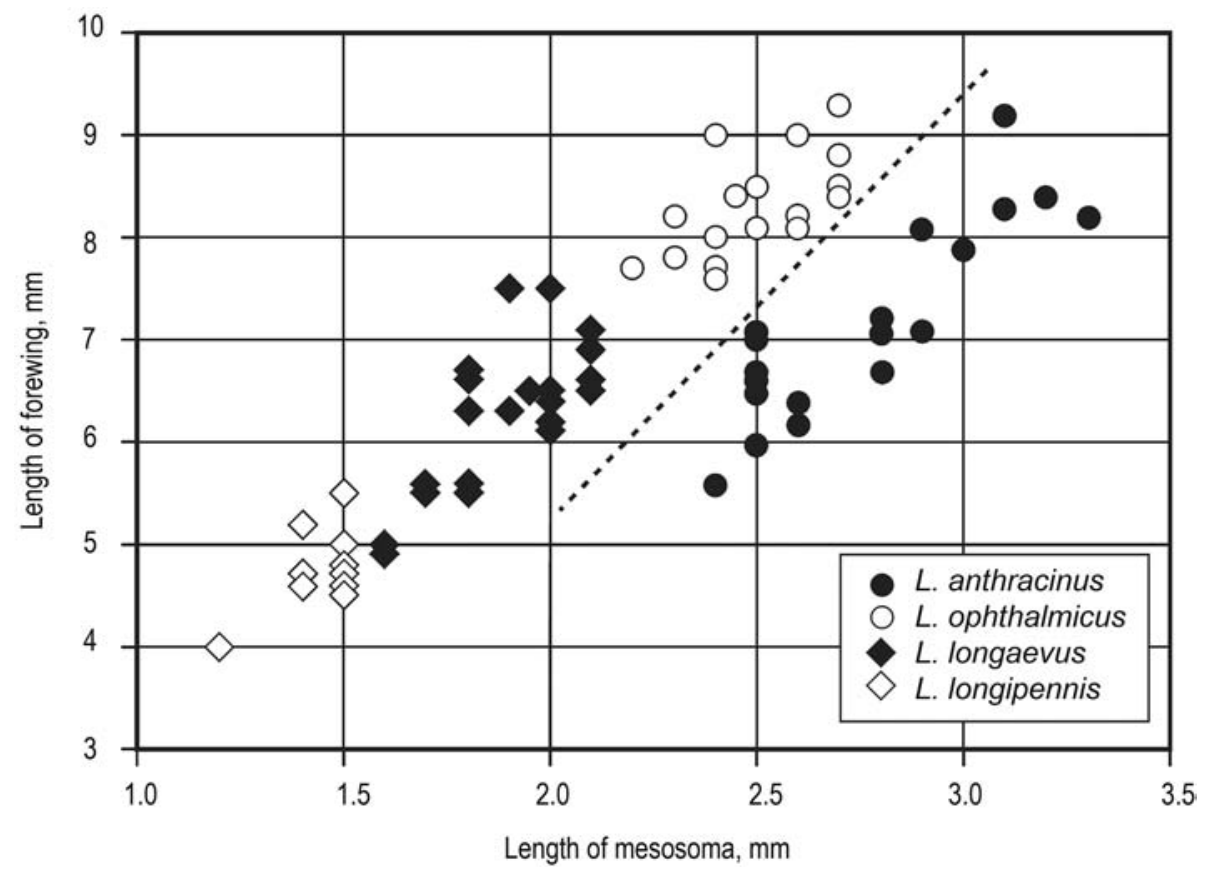

Fig. 10. Relationship between mesosoma length and forewing length of species of Lasius.

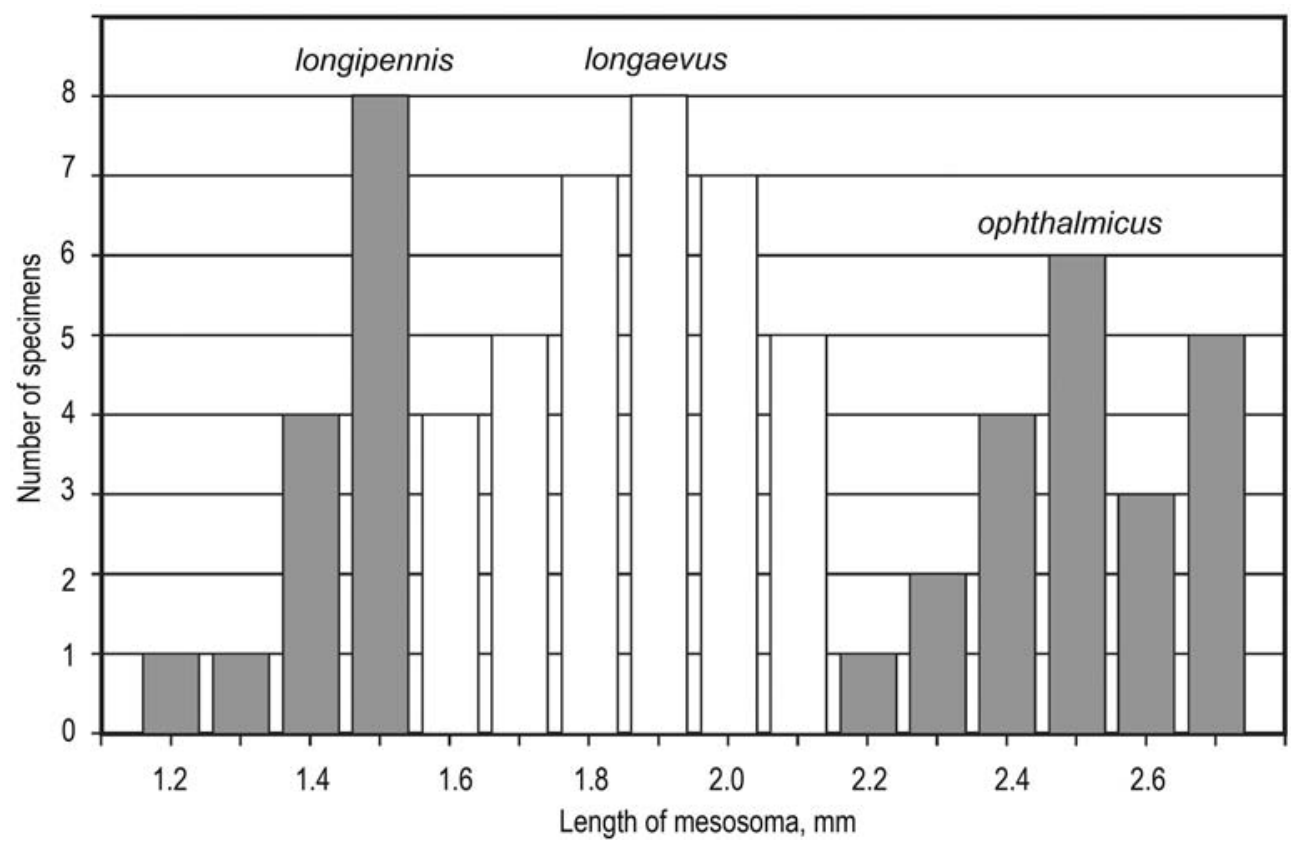

Fig. 11. Frequency distributions of mesosoma length classes among gynes of three species of Lasius. 
this species. However, as the wing venation had not been preserved, the imprints do not allow identifying them to genus with certainty.

\section{Formica parexsecta $\mathrm{n}$. sp. Figs. 9H, 17F}

Etymology: Name from the Greek para (near) and species name exsecta.

Studied material: Holotype GBA no. 2009/016/0355 ( $($, identified as Formica redtenbacheri).

Diagnosis: Differs from all Miocene Formicinae in the elongate head with a concave occipital margin.

Description: Gyne. BL=9 $\mathrm{mm}$. Head longer than wide (HL/HW=1.13), with weakly convex sides, rounded occipital corners, and concave occipital margin. Anterior margin of clypeus rounded. Mesosoma elongate, twice as long as wide. Wing venation not visible.

Measurements of holotype, in mm: $\mathrm{AL}=3.2, \mathrm{AW}=1.6$, $\mathrm{HL}=1.7, \mathrm{HW}=1.5$.

Remarks: F. parexsecta is outwardly similar to Recent species of Formica exsecta group (subgenus Coptoformica).

\section{Genus Lasius FABRICIUS, 1804.}

Type species: Formica nigra Linnaeus, 1758; by subsequent designation by BinGHAM 1903, p. 338 .

Diagnosis (for compression fossils): Gyne. Waist consisting of one segment (petiole) with scale; gaster without constriction between first and second gastral (III and IV abdominal) segments. Head with rounded occipital angles. Anterior margin of clypeus rounded. With head in full-face view the eyes distinctly behind the midlength of the side of the head; gena much longer than maximum eye diameter. Mandibles triangular, dentate. Antennae 12-segmented; scape protruding beyond posterior margin of head. Second to fifth joints of funiculus 1.0-1.4 times as long as wide (except in subgenus Dendrolasius). Antennal insertion near posterior margin of clypeus. Hind coxae broadly separated. Forewing with closed cells $1+2 \mathrm{r}$, $3 \mathrm{r}$, and mcu; free branches $5 \mathrm{RS}$ and $4 \mathrm{M}$ leaving cell $1+2 \mathrm{r}$ from common expanded region; $4 \mathrm{M}$ strongly curved basally; section 2-3RS straight or weakly convex. Icu>1.45. Gynes 1.5-2.2 times as large as males (except in subgenus Austrolasius).

Species numbers and distribution: A total of 111 extant species and 3 subspecies of Lasius, living in the Palearctic and Nearctic, and 25 extinct species and subspecies have been described to date (www.antweb.org, accessed 7 March 2014). Four of the extinct species have been described from Late Eocene ambers of Europe (DLussky 2011), three from Oligocene deposits of France (ThÉobald 1937), one from
Oligocene deposits of the United States (CARPENTER 1930), four from Miocene deposits of China (ZHANG 1989), and 13 from Miocene deposits of Europe. Ten of the latter 13 taxa were originally described by HeER from Radoboj in the genus Formica, but subsequently transferred to the genus Lasius (HANDLIRSCH 1907). In this revision some of the extinct species described from Radoboj are synonymised, and some are transferred to this genus from the genus Formica. As a result, six species of the genus Lasius are known from Radoboj currently.

Remarks: Species of the genus Lasius make up about one half of all ants recorded in Radoboj. Their variation is clearly greater than can be observed within one species in extant members of the genus. In any extant species of $\mathrm{La}$ sius, the difference in length between the smallest and the largest gynes is $67 \%$ to $90 \%$, with an average of $77 \%$, and between the smallest and largest males $67 \%$ to $88 \%$, with an average of 79\%. In gynes from Radoboj, the length of the mesosoma is $1.2 \mathrm{~mm}$ in the smallest and $3.3 \mathrm{~mm}$ in the largest. Assuming that the variation was similar to that of extant species, the mesosoma length had to be $1.2-1.55 \mathrm{~mm}$ in the smallest species and $2.5-3.3 \mathrm{~mm}$ in the largest. It has to be taken into account that the compression fossils are distorted and may differ in size from the actual ants, making the variation greater than in extant species - but even then we clearly have several species. Unfortunately, the material is so poorly preserved that the characters by which extant species and species from Late Eocene ambers of Europe are distinguished are not visible in the imprints. However, we have divided the gynes into five species based on morphometric characters. Two of these species are clearly distinguished by proportions. In L. globularis the head is longer than wide, whereas in all other species it is wider than long (Fig. 7). L. anthracinus has relatively short wings (Fig. 10). In this species the forewing is 2.3-2.9 times as long as the mesosoma, whereas in the other species it is more than 3 times as long as the mesosoma. The other species have similar proportions, but differ in size (Fig. 11). The frequency distribution of this group by the length of the mesosoma has three maximums: $1.5,1.9$ and $2.5 \mathrm{~mm}$. We found no hiatuses, and therefore provisionally divided this group into three species with the length of the mesosoma 1.2-1.5, 1.62.1 and $2.2-2.7 \mathrm{~mm}$, ranges approximately equivalent to the intraspecific variation found in extant species. Unfortunately, we have failed to find any characters that would allow us to divide the males similarly into several species. Therefore, we describe the males of Lasius from Radoboj as one form species (morphospecies).

Lasius anthracinus (HEER, 1867) n. comb. Figs. 12A, 17B

1867 Poneropsis anthracinus HeER 1867, p. 22, pl. 2, fig. $8\left(0^{7}\right)$.

1867 Hypoclinea anthracina (HeER, 1867). - MAYr, p. 57.

1878 Dolichoderus anthracinus (HEER, 1867). - Forel, p. 186.

1907 Dolichoderus anthracinus (HeER, 1867). - HAND- 
LIRSCH, p. 870.

1964 Formicidae incertae generis. - TAYLOR, p. 138.

1994 Dolichoderus anthracinus (HEER, 1867). - SHATTUCK, p. 42.

1995 Dolichoderus anthracinus (HeER, 1867). - Bolton, p. 172.

Neotype of Poneropsis anthracinus GBA no. 2009/016/0074 (ㅇ, designated here).

\begin{abstract}
Other studied material: (우).GBA: 2009/016/0140, 2009/016/0196, 2009/016/0239, 2009/016/0245, 2009/016/0393, 2009/016/0424, 2009/016/0503, 2009/016/0513, 2009/016/0649, 2009/016/9021. UMJG\&P: 77.497, 77.506, 77.590. NHMW: 1852.XXIX.34, 1852. XXIX.5a (2), 1852.XXIX.8, 1877.XXV.15, 1877.XXV.16, five specimens without numbers.
\end{abstract}

Diagnosis: Differs from L. globularis in the relatively wide head and large size, and from the other species of Lasius from Radoboj in its relatively short wings.

Description: Gyne. BL 5.1-10 mm, AL 1.9-3.3 mm. Head wider than long: HL/HW 0.82-0.96 (average 0.91, n=7). Occipital angles rounded, occipital margin weakly convex. Anterior margin of clypeus rounded. Scape longer than head. Second to fifth joints of funiculus nearly twice as long as wide. Mesosoma 1.4-1.9 times as long as wide. Propodeum angulate in side view; propodeal dorsum much shorter than declivity. Legs moderately short and thick. Petiole nearly twice as high as long. Gaster oval. Forewings usually shorter than body $(\mathrm{FWL} / \mathrm{BL}=0.7-1.0$, average $0.9, \mathrm{n}=15)$ and $2.3-3.0$ (average 2.6, n=22) times as long as mesosoma. Cell mcu trapezoid; vein section $1 \mathrm{Cu}$ 1.6-2.0 times as long as RS+M.

Measurements, in mm: Neotype: $\mathrm{BL}=9.5, \mathrm{AL}=3.0$, $\mathrm{HL}=1.9, \mathrm{FWL}=7.9$. Variation: $\mathrm{BL}$ 5.1-10.0 (average 8.2, $\mathrm{n}=15$ ), AL 1.9-3.3 (average 2.7, $\mathrm{n}=24$ ), HL 1.0-1.9 (average 1.5, $\mathrm{n}=10$ ), HW 1.2-2.0 (average 1.6, n=9), FWL 5.3-9.2 (average $7.0, \mathrm{n}=22$ ).

Remarks: This species was described from four specimens, which have all been lost. We found in the collection of GBA two specimens, one of which (2009/016/0074), identified by HeEr (which is certain), we designate as the neotype. MAYR (1867) examined one male identified by HEER, and placed it in the genus Hypoclinea. Subsequently, Forel (1878) syno- nymised the genus Hypoclinea MAYr, 1755 (type species Formica quadripunctata LinNAEUs, 1771) under the genus Dolichoderus Lund, 1831, automatically transferring $H$. anthracina to the latter genus. This status was later accepted for this species by HANDLIRSCH (1907). In his revision of the fossil species of the genus Ponera, TAYLOR (1964) treated this species as Formicidae incertae generis, but then SHATTUCK (1994) reinstated it in the genus Dolichoderus. Actually, the neotype of Poneropsis anthracinus doubtlessly belongs to the genus Lasius.

Lasius ophthalmicus (HEER, 1849) n. comb. Fig. 12B-C

1849 Formica ophthalmica HeER, p. 125, pl. 9, fig. 9, pl. 10. Fig. 9e (ㅇ).

1849 Formica macrocephala radobojana HeER, p. 126, pl. 9, fig. 10a, b. (o) , n. syn.

1867 Formica ophthalmica HeER, 1849 - HeER, p. 11.

1867 Formica macrocephala HeER, 1849 - HeER, p. 12, pl. 1, fig. 11, n. syn.

1867 Formica ophthalmica HeEr, 1849 - MAYr, p. 52.

1867 Formica macrocephala radobojana HEER, 1849 MAYR, p. 53, n. syn.

1907 Formica macrocephala radobojana HeER, 1849 HANDLIRSCH, p. 864, n. syn.

1907 Formica ophthalmica HeER, 1849 - HandLIRSCH, p. 865.

1995 Formica ophthalmica Heer, 1849 - Bolton, p. 200.

1995 Formica macrocephala: HeEr, 1849 - Bolton, p. 198 (as unresolved junior primary homonym of Formica macrocephala ERICHSON, 1842), n. syn.

Studied types: Lectotype of Formica ophthalmica UMJG\&P no. 77.646e (designated here, + , figured by HeER 1849: pl. 9, fig. 9, pl. 10, fig. 9e). Neotype of Formica macrocephala radobojana UMJG\&P no. 77.539 (designated here, , figured by HEER 1867: pl. 1, fig. 11).

Other studied material: (우). GBA: 2009/016/0110, 2009/016/0123, 2009/016/0194, 2009/016/0204, 2009/016/0275, 2009/016/0291, 2009/016/0330, 2009/016/0351, 2009/016/0509, 2009/016/0536, 2009/016/0556, 2009/016/0663. UMJG\&P: 77.492, 77.496, 77.508, 77.517, 77.557, 77.588. NHMW: 1852.XXIX.12, 1852.XXIX.13, 1877.XXV.18c, PSWH Coll 2001b (2).

Fig. 12. Species of the genus Lasius. A - L. anthracinus (HeER, 1867), neotype of Poneropsis anthracinus HeER, 1867, GBA no. 2009/016/0074 (); B-C - L. ophthalmicus (HeER, 1849); B - lectotype of Formica ophthalmica HeER, 1849, UMJG\&P no. 77.646e (); C - neotype of Formica macrocephala radobojana HeER, 1849, UMJG\&P no. 77.539 ( $\%) ;$ D - L. longaevus (HeER, 1849), lectotype of Formica longaeva HeER, 1849, UMJG\&P no. 77.580 (O); E - L. longipennis (HeER, 1849), lectotype of Formica longipennis HeER, 1849, UMJG\&P no. 77.503 (\$); F - L. globularis (HeER, 1849), lectotype of Formica globularis HeER, 1849, UMJG\&P no. 77.635 (\$); G-J - L. occultatus (HeER, 1849); G - lectotype of Formica

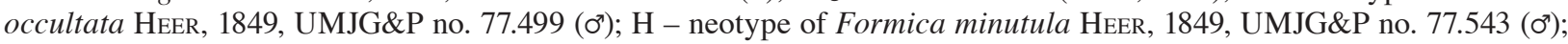
I - lectotype of Formica pumila HeER, 1849, UMJG\&P no. 77.644b (ơ); J - neotype of Formica obliterata HeER, 1849, UMJG\&P no. $77.565\left(\sigma^{7}\right)$. 


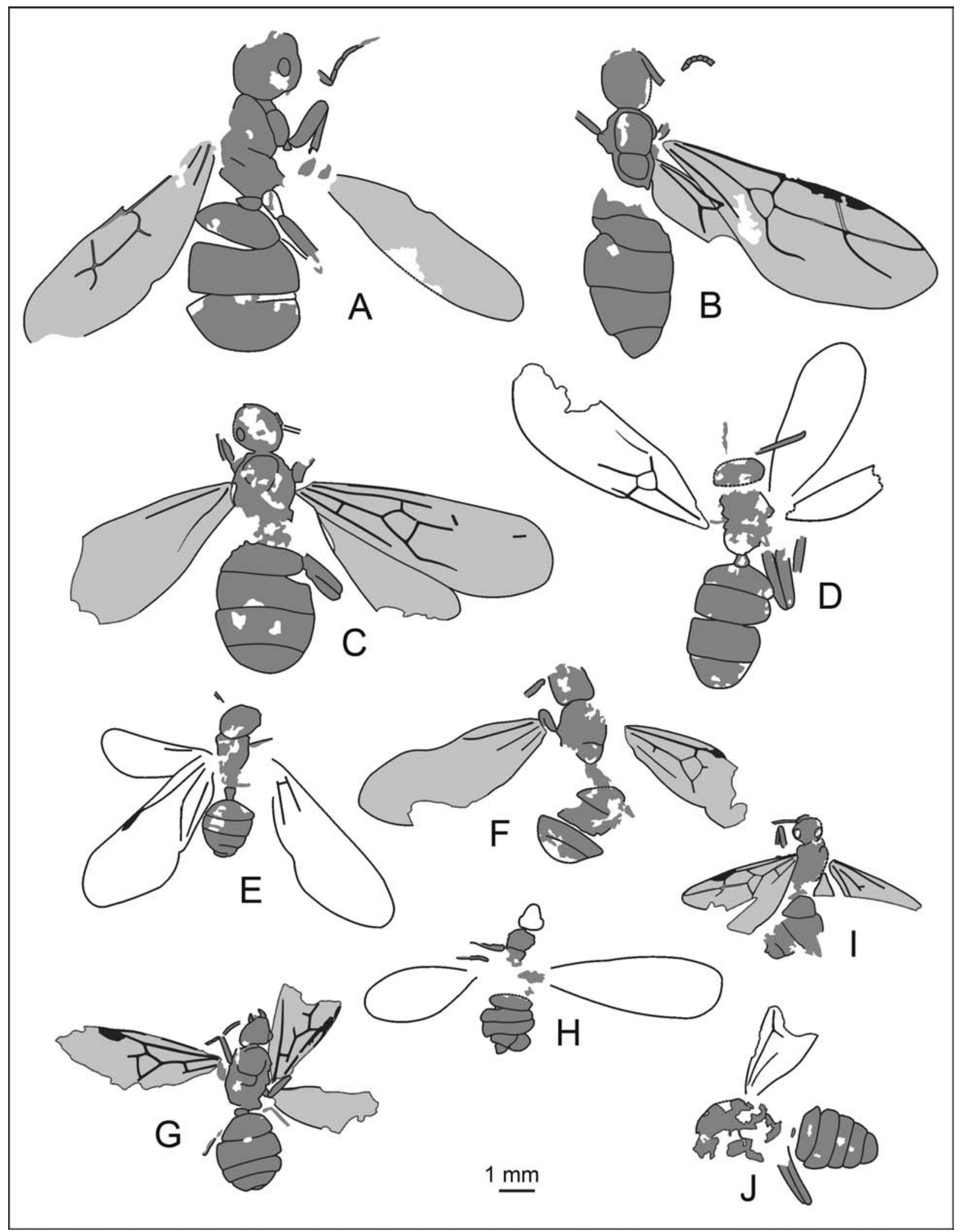

Fig. 12. 
Diagnosis: Differs from L. anthracunus in the longer forewings and from L. globularis in the wider head.

Description: Gyne. BL 6.5-8.8 mm, AL 2.2-2.7 mm. Head wider than long: HL/HW 0.85-0.99 (average 0.91, n=8). Occipital angles rounded, occipital margin straight or weakly convex. Anterior margin of clypeus rounded. Scape a little longer than head. Second to fifth joints of funiculus 1.4-1.5 times as long as wide. Mesosoma 1.2-1.7 (average 1.5, $\mathrm{n}=16$ ) times as long as wide. Scutum longer than wide. Propodeum rounded in side view. Legs moderately short and thick. Gaster oval. Forewings usually longer than body (FWL/ $\mathrm{BL}=0.9-1.3$, average $1.1, \mathrm{n}=17$ ) and 3.1-3.8 (average 3.3, $\mathrm{n}=18$ ) times as long as mesosoma. Cell mcu trapezoid; vein section $1 \mathrm{Cu}$ 1.75-2.3 (average 2.0) times as long as RS+M.

Measurements, in mm: Lectotype of $F$. ophthalmica UMJG\&P no. 77.646e: $\mathrm{BL}=8.8, \mathrm{AL}=2.7, \mathrm{AW}=1.6, \mathrm{HL}=1.5$, $\mathrm{FWL}=8.8$; neotype of $F$. macrocephala radobojana UMJG\&P no. 77.539: $\mathrm{BL}=7.8, \mathrm{AL}=2.4, \mathrm{AW}=1.6, \mathrm{HL}=1.3$, $\mathrm{HW}=1.4, \mathrm{FWL}=8.0$. Variation: $\mathrm{BL}$ 6.5-8.8 (average 7.55, $\mathrm{n}=19$ ), AL 2.2-2.7 (average 2.50, $\mathrm{n}=21$ ), AW=1.4-2.0 (average 1.71, $\mathrm{n}=16$ ), $\mathrm{HL}=1.1-1.8$ (average 1.41, $\mathrm{n}=10$ ), HW 1.31.8 (average 1.46, $\mathrm{n}=17$ ), FWL 7.1-9.3 (average 8.25, $\mathrm{n}=21$ )

Remarks: HeER described Formica ophthalmica from six specimens. The collection of UMJG\&P contains five specimens labelled as syntypes. We identified specimens UMJG\&P no. 77.502 and 516 as Formica ungeri. The second of these was depicted (HeER 1849, pl. 9, fig. 9b), but the interpretation of the imprint is incorrect. HEER took the folds formed on the head as a result of distortion of the imprint for very large oval eyes. It was based on this character that he described this species as new. However, actually this specimen has a clearly visible left eye, which has a shape normal for Formica. In all other imprints, the eyes are invisible, and it is unclear why HeER placed those imprints in this species. Three specimens are located on one piece of rock (UMJG\&P no. 77.646), but only one of them is sufficiently well-preserved and can be safely identified as Lasius. We designate this specimen here as the lectotype. MAYR (1867) examined nine specimens identified by HeEr. Seven of them belonged to the genus Formica, one to Lasius, and one to Myrmicinae. Based on those results, HANDLIRSCH (1907) left the species in the genus Formica.

Formica macrocephala was described by HeER (1849) from Oeningen, and he described specimens from Radoboj that he placed in the same species as Formica macrocephala radobojana. The collection of UMJG\&P contains seven specimens identified by HEER as $F$. macrocephala, but none of them complies with the figures provided in the 1849 publication. However, they include specimen UMJG\&P no. 77.539, which was figured in the 1867 publication. It cannot be considered a syntype, and therefore we designate it here as the neotype. MAYR (1867) left this species in the genus Formica. According to HeER's description, F. macrocepha$l a$ differs from $F$. ophthalmica in the more rounded scale, but actually the shape of the scale is not visible clearly in any of the imprints. We could not find any principal differences between the types of these species.

\section{Lasius longaevus (HeER, 1849)}

Fig. 12D

1849 Formica longaeva HeER, p. 132, pl. 10, fig. 4 (\$).

1867 Formica longaeva HeEr, 1849. - HeER, p. 14.

1867 Lasius longaevus (HeER, 1849). - MAYr, p. 54.

1907 Lasius longaevus (HeER, 1849). - HANDLIRSCH, 861.

1995 Lasius longaevus (HeER, 1849). - Bolton, p. 223.

Lectotype UMJG\&P no. 77.580 (designated here, ㅇ, figured by HeER 1849: pl. 10, fig. 4).

Other studied material: (ㅇ). GBA: 2009/016/0024, 2009/016/0036, 2009/016/0037 $\quad$ (2), 2009/016/0046, 2009/016/0199, 2009/016/0203, 2009/016/0217, 2009/016/0299, 2009/016/0352, 2009/016/0377, 2009/016/0402, 2009/016/0482, 2009/016/0487, 2009/016/0541, 2009/016/0606, 2009/016/0622a, 2009/016/0659, 2009/016/0677. UMJG\&P: 77.504, 77.511, 77.570, 77.575, 211 031. NHMW: 1842.I.21, 1852.XXIX.26, 1852.XXIX.7, K.K. Polytech. Institut, 1868, 4 specimens without numbers.

Diagnosis: Similar to L. ophthalmicus and differs from it in the smaller size.

Description: Gyne. BL 3.8-6.7 mm, AL 1.6-2.1 mm. Head wider than long: HL/HW 0.77-0.97 (average 0.90, $\mathrm{n}=16$ ). Occipital angles rounded, occipital margin weakly convex or stright. Anterior margin of clypeus rounded. Scape a little longer than head. Mesosoma 1.2-1.7 (average 1.4, $\mathrm{n}=23$ ) times as long as wide. Propodeum rounded in side view. Legs moderately short and thick. Gaster oval. Forewings nearly as long as body $(\mathrm{FWL} / \mathrm{BL}=0.9-1.3$, average 0.9 , $\mathrm{n}=15$ ) and 3.05-3.9 (average 3.3, $\mathrm{n}=24$ ) times as long as mesosoma; cell mcu trapezoidal; vein section $1 \mathrm{Cu}$ 1.6-1.8 times as long as $\mathrm{RS}+\mathrm{M}$.

Measurements, in mm: Lectotype UMJG\&P no. 77.580: $\mathrm{BL}=6.5, \mathrm{AL}=2.1, \mathrm{AW}=1.3, \mathrm{HW}=1.2, \mathrm{FWL}=6.9$. Variation: BL 3.8-6.7 (average 5.47, $\mathrm{n}=29$ ), AL 1.6-2.1 (average 1.87, $\mathrm{n}=35$ ), AW 1.0-1.7 (average 1.33, $\mathrm{n}=23$ ), HL 0.77-1.5 (average 1.01, $n=19$ ), HW 0.82-1.7 (average 1.13, n=21), FWL 4.97.5 (average 6.20, $\mathrm{n}=24$ ).

Remarks: HeER described this species from two specimens, one of which, depicted in pl. 10, fig. 4, has been preserved in the UMJG\&P collection, and we designate it as the lectotype. HeER distinguished Formica longaeva from other species of Formicinae ("Formica") by the shape of the petiole and gaster. However, in the lectotype of this species, the petiole is deformed, and the shape of the gaster can never really be used as a diagnostic character for compression fossils. MAYR (1867) examined six specimens and identified four of them as Lasius, and two as Myrmicinae of unclear generic placement. Following these identifications, HaNDLIRSCH (1907) placed this species in the genus Lasius.

Lasius longipennis (HEER, 1849)

Fig. 12E 
1849 Formica longipennis HeER, p. 136, pl. 10, fig. 7 (\%). 1867 Lasius longipennis (HEER, 1849). - MAYR, p. 55.

1907 Lasius longaevus (HeER, 1849). - HandLIRSCh, 864.

1995 Lasius longaevus (Heer, 1849). - Bolton, p. 223.

Lectotype: UMJG\&P no. 77.503 (designated here, $\$$, figured by Heer, 1849: pl. 10, fig. 7).

Other studied material: (\%)). GBA: 2009/016/0098, 2009/016/0141, 2009/016/0151, 2009/016/0274, 2009/016/0344, 2009/016/0404, 2009/016/0566. UMJG\&P: 77.644a (syntype of Formica pumila figured by HeER, 1849: pl. 11, fig. 15a), 77.646h (syntype of Formica pumila figured by Heer, 1849: pl. 10, fig. 9h). NHMW: 1852.I.1048, 1902.III.217, Jahr 1868, o without number.

Diagnosis: Similar to L. ophthalmicus L. and L. longaevus and differs from them in its significantly smaller size.

Description: Gyne. BL 3.6-6.1 mm, AL 1.2-1.5 mm. Head usually slightly wider than long: HL/HW 0.8-1.0 (average $0.90, \mathrm{n}=5$ ). Occipital angles rounded, occipital margin weakly convex. Anterior margin of clypeus rounded. Scape longer than head. Mesosoma 1.2-1.5 (average 1.35, $\mathrm{n}=5$ ) times as long as wide. Propodeum rounded in side view. Legs moderately short and thick. Gaster oval. Forewings nearly as long as body ( $\mathrm{FWL} / \mathrm{BL}=0.9-1.3$, average 1.1 , $\mathrm{n}=11$ ), and 3.0-3.7 (average 3.3, $\mathrm{n}=11$ ) times as long as mesosoma; cell mcu trapezoidal.

Measurements, in mm: Lectotype: $\mathrm{BL}=4.2, \mathrm{AL}=1.5$, $\mathrm{FWL}=5.5$. Variation: BL 3.6-6.1 (average 4.40, $\mathrm{n}=14$ ), AL 1.2-1.5 (average 1.43, $\mathrm{n}=14$ ), AW 0.9-1.3 (average 1.05, $\mathrm{n}=5$ ), HL 0.7-1.0 (average 0.83, $\mathrm{n}=7$ ), HW 0.8-1.1 (average 0.91, $\mathrm{n}=5$ ), FWL 4.0-5.5 (average 4.75, $\mathrm{n}=11$ ).

Remarks: HeER (1849) described this species from two specimens, one of which, depicted in pl. 10, fig. 7, has been preserved, and we designate it as the lectotype. According to the original description, this species differs from the other "Formica" in its longer wings. However, some specimens that HeER identified as other species (including the lectotypes of $F$. globularis and $F$. ophthalmica), have wings that are just as long. MAYR (1867) examined two specimens identified by Heer, one of which was a male Lasius, and the other was not an ant. Based on this, HaNDLIRSCH (1907) placed this species in the genus Lasius.

\section{Lasius globularis (HEER, 1849)}

Fig. $12 \mathrm{~F}$

1849 Formica globularis HeER, p. 131, pl. 10, fig. 3 (†).

1867 Formica globularis Heer, 1849. - Heer, p. 14.

1867 Formica capito Heer, p. 14, pl. 1, fig. 13 (†), n. syn.

1867 Lasius globularis (HEER, 1849). - MAYR, p. 54.

1907 Lasius globularis (HeER, 1849). - HandLIRSCh, p. 862

1907 Formica capito HeER, 1867.-HandLIRSCh, 863, n. syn.

1995 Formica capito HeER, 1867. - Bolton, p. 162, n. syn.

1995 Lasius globularis (HeER, 1849.) - Bolton, p. 223.
Lectotype: UMJG\&P no. 77.635 (designated here, ㅇ, figured by HeER, 1849: pl. 10, fig. 3).

Other studied material: (\%). GBA: 2009/016/0182, 2009/016/0394, 2009/016/0624. UMJG\&P: 77.552, 77.567. NHMW: 1852.XXIX.14.

Diagnosis: Differs from the other species of Lasius from Radoboj based on its longer head. Differs from Formica ungeri in its smaller size.

Description: Gyne. BL 4.4-7.0 mm, AL 1.6-2.1 mm. Head longer than wide: HL/HW 1.02-1.33 (average 1.1, n=6). Occipital angles rounded, occipital margin weakly convex. Anterior margin of clypeus rounded. Scape longer than head. Mesosoma 1.5-1.9 (average 1.6, $\mathrm{n}=4$ ) times as long as wide. Scutum nearly as long as wide. Propodeum rounded in side view. Gaster oval. Forewings nearly usually shorter than body $(\mathrm{FWL} / \mathrm{BL}=0.8-1.05$, average $1.0, \mathrm{n}=7)$ and 2.8 3.2 (average 3.0, $\mathrm{n}=6$ ) times as long as mesosoma. Cell $\mathrm{mcu}$ trapezoid.

Measurements, in mm: Lectotype: $\mathrm{BL}=6.0, \mathrm{AL}=2.1$, $\mathrm{AW}=1.2, \mathrm{HL}=1.2, \mathrm{HW}=1.1, \mathrm{FWL}=6.3$. Variation: $\mathrm{BL}$ 4.47.0 (average 5.75, $\mathrm{n}=9$ ), AL 1.6-2.1 (average 1.87, $\mathrm{n}=8$ ), AW 1.0-1.3 (average 1.14, $\mathrm{n}=4$ ), HL 0.7-1.4 (average 1.13, $\mathrm{n}=8$ ), HW 0.7-1.2 (average 0.98, n=7), FWL 5.0-6.6 (average 5.72, $n=7)$.

Remarks: We designate as the lectotype specimen UMJG\&P no. 77.635 , depicted by HeER in pl. 10, fig. 7. MAYR (1867) identified most of the specimens he had examined as Lasius, but one of them proved to be a male Formica, and one was described by MAYR as Liometopum antiquum. Based on this, HandLIRSCH (1907) placed this species in the genus Lasius.

HeER described Formica capito from a single specimen, which has not been preserved. MAYR (1867) had not seen this species. We have also failed to find it in the studied collections. Judging by the figure and description, this species is most likely a junior synonym of Lasius globularis. Apparently, the poorly preserved specimens GBA no. 2009/016/0134, UMJG\&P no. 77.522, NHMW no 1852.I.1035, and three specimens without numbers (one of them this label "Jahr, 1868") also belong to this species.

\section{Lasius occultatus (HeER, 1849)} Fig. 12G-J

1849 Formica occultata HeER, p. 134, pl. 10, fig. 6, pl. 11,

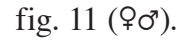

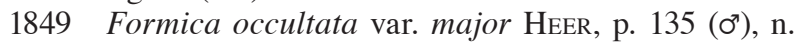
syn.

1849 Formica minutula Heer, p. 136, pl. 10, fig. 8 (\%), n. syn.

1849 Formica pumila HeER, p. 137, pl. 10, fig. 9g, h, pl. 11, figs. 14d, e, 15a, b ( $\left.\odot^{7}\right)$, n. syn.

1849 Formica obliterata HeER, p. 144, pl. 11, figs. 11c, 12 b (ơ), n. syn. 
1867 Formica occultata Heer, 1849. - Heer, p. 15.

1867 Formica minutula HeER, 1849. - HeEr, p. 16, pl. 1, fig. 15, n. syn.

1867 Formica obliterata HeER, 1849. - HeER, p. 18, n. syn.

1867 Lasius occultatus (HEer, 1849). - MAYr, p. 54.

1867 Lasius minutulus (HeER, 1849). - MAYr, p. 55, n. syn.

1867 Lasius obliteratus (HEER, 1849). - MAYr, p. 55, n. syn.

1907 Lasius occultatus (HeER, 1849). - HANDLIRSCH, p. 860.

1907 Lasius minutulus (HeER, 1849). - Handlirsch, p. $861, n$. syn.

1907 Lasius obliteratus (Heer, 1849). - Handlirsch, p. 861, n. syn.

1907 Formica pumila HeEr, 1849. - Handlirsch, p. 865, n. syn.

1995 Formica pumila Heer, 1849. - Bolton, p. 202, n. syn.

1995 Lasius minutulus (Heer, 1849). - Bolton, p. 224, n. syn.

1995 Lasius obliteratus (HeER, 1849). - Bolton, p. 225, n. syn.

1995 Lasius occultatus (Heer, 1849). - Bolton, p. 225.

Studied types: Lectotype of Formica occultata UMJG\&P no. 77.499 (designated here, $\sigma^{7}$ ). Neotype of Formica minutula UMJG\&P no. 77.543 (designated here, o'). Lectotype of Formica pumila UMJG\&P no. 77.644b, (designated here, o", figured by HeER, 1849: pl. 11, fig. 15b). Neotype of Formica obliterata UMJG\&P no. 77.565 (designated here, ơ).

Other studied material: $\left(0^{\top} \sigma^{7}\right)$. GBA: 2009/016/0015, 2009/016/0025, 2009/016/0072 (2), 2009/016/0167, 2009/016/0172, 2009/016/0276, 2009/016/0302, 2009/016/0312, 2009/016/0323, 2009/016/0329, 2009/016/0348, 2009/016/0366, 2009/016/0426, 2009/016/0444, 2009/016/0457, 2009/016/0484, 2009/016/0506, 2009/016/0511, 2009/016/0520, 2009/016/0529, 2009/016/0588, 2009/016/0589, 2009/016/0604, 2009/016/0619, 2009/016/0622b, 2009/016/0626, 2009/016/0628. UMJG\&P: 77.505, $77.512,77.514,77.529,77.579,77.587,211$ 030. NHMW: 1852.I.1032, 1852.I.1047, 1852.I.1049, 1852.XXIX.18, 1852. XXIX.20, 1852.XXIX.21b, 1852.XXIX.22.

Diagnosis: We provisionally place in this species males of several species of the genus Lasius that cannot be distinguished when preserved as compression fossils. The males are readily distinguishable from gynes, because they have five visible gastral segments (rather than four, as in gynes). They differ from males of the genus Formica in the smaller size and forewing venation (see diagnoses of the respective genera), but lack diagnostic features of their own.

Description: Male. BL 3.7-5.9 mm, AL 1.2-2.1 mm. Head wider than long: HL/HW 0.83-0.90. Eyes large. Scape longer than head. Mesosoma 1.3-1.6 (average 1.43, $\mathrm{n}=16$ ) times as long as wide and 1.4-1.8 (average 1.61, $\mathrm{n}=7$ ) times as long as high. Scutum weakly convex in side view and wider than long. Propodeum rounded in side view. Petiole triangulate in side view and nearly as long as wide. Forewing 0.85-1.3 (average 1.05, $\mathrm{n}=18$ ) times as long as body and 2.3-3.7 (average $2.84, \mathrm{n}=34$ ) times as long as mesosoma.

Measurements, in $\mathbf{m m}$ : Lectotype of $F$. occultata UMJG\&P no. 77.499: $\mathrm{BL}=5.2, \mathrm{AL}=1.9, \mathrm{HL}=0.74$, hw=0.87, FWL $=4.4$. Neotype of $F$. minutula UMJG\&P no. 77.543: $\mathrm{BL}=4.5, \mathrm{AL}=1.6, \mathrm{FWL}=4.9$. Lectotype of $\mathrm{F}$. pumila UMJG\&P no. 77.644b: $\mathrm{BL}=4.2, \mathrm{AL}=1.4, \mathrm{HL}=0.7, \mathrm{HW}=0.8$, $\mathrm{FWL}=3.7$. Neotype of $F$. obliterata UMJG\&P no. 77.565: $\mathrm{BL}=5.9, \mathrm{AL}=2.1, \mathrm{FWL}=5.6$. Variation: $\mathrm{BL}$ 3.7-5.9 (average 4.72, $\mathrm{n}=22$ ), AL 1.2-2.1 (average 1.71, $\mathrm{n}=44$ ), HL 0.70-0.93 (average 0.82, n=7), HW 0.78-1.03 (average 0.92, $\mathrm{n}=4$ ), FWL 3.4-6.8 (average 4.88, $\mathrm{n}=35$ ).

Remarks: As noted above, males of Formica and Lasius are readily distinguishable by size (Fig. 8). Although the set of Lasius males, which includes the types of four species described by HeER, obviously consists of several species, we could find no characters by which these species could be distinguished. As can be seen from the figure, the frequency distribution of these males by size is unimodal. Therefore, we place all males of this genus in one form species.

HeER (1849) described Formica occultata from 63 specimens and identified a total of 594 specimens of this species (HeEr, 1867). We examined 117 specimens identified by HeER; 59 of them are so poorly preserved that could not be placed in any species. The others proved to represent nine species of five genera and three subfamilies. The collection of UMJG\&P contains 17 specimens labelled as syntypes, but none of them complies with HeER's figures. We designate as the lectotype the best-preserved male specimen, UMJG\&P no. 77.499. According to MAYR (1867), the majority of specimens identified by HEER as Formica occultata belong to the genus Lasius, but one specimen was described by MAYR as Hypoclinea haueri. Based on this, HANDLIRSCH (1907) transferred this species to Lasius.

The variety Formica occultata var. major was described from a single imprint of a male without a head. According to the HeER's description, it is similar to Formica occultata and differs from it only in the slightly larger size. This specimen has not been preserved.

HeER (1849) described Formica minutula from a single whole gyne and two fragments. We have examined 17 specimens identified by HeER; six of them proved to be males of the genus Lasius, one proved to be a gyne of L. longipennis, and the others are poorly preserved and cannot be identified to genus. None of these specimens complies with HeER's figure. Male specimen UMJG\&P no. 77.543 is labelled as a syntype, but it cannot be considered a syntype of this species, because it does not comply with HeER's figure. Therefore, we designate it as neotype. MAYR (1867) examined two specimens, which he identified as males of Lasius. Based on this, HandLIRSCH (1907) transferred this species to the genus Lasius.

HeER (1849) described Formica pumila from six imprints found in three large pieces of rock, UMJG\&P nos. 77.644, 77.645 and 77.646, together with imprints of other insects, mostly ants. We designate as the lectotype the bestpreserved male specimen UMJG\&P no. 77.644b, depicted by HeER in pl. 11, fig. 15b. MAYR (1867) examined three 
specimens identified by HEER as $F$. pumila and wrote that they could belong to three different species and even genera, but could not be identified because of the poorly preserved imprints. Based on this, HANDLIRSCH (1907) left this species in the genus Formica.

HeER (1849) described Formica obliterata from two males, which had no wings preserved. He also noted that the species was very similar to $F$. occultata and differed from it in the slightly larger size. Neither of these specimens has been preserved. The collection of UMJG\&P contains six specimens labelled as syntypes, but they cannot be considered syntypes, because they do not comply with HEER's figures. Two of them are males of F. ungeri, one is a $F$. globularis gyne, one is poorly preserved and cannot be identified, and two are males of the genus Lasius. We designate one of these males (UMJG\&P no. 77.565) as the lectotype. MAYR (1867) examined four specimens indentified by HEER and, although he could not discern the wing venation, suggested that they were probably males of the genus Lasius. Based on this, HANDLIRSCH (1907) transferred this species to the genus Lasius.

Subfamily Amblyoponinae Forel, 1893

Morphogenus Casaleia Pagliano \& Scaramozzino, 1990

Type species: Protamblyopone inversa Dlussky, 1981, by original designation.

Diagnosis (for compression fossils): Gyne. Petiole essentially sessile, with steep, broad anterior face, but without distinctly descending posterior face, and markedly broadly attached to first gastral (III abdominal) segment. Helcium protruding from very high on anterior face of first gastral segment; first gastral segment above helcium without free anterior face. Mandible triangular. Eyes rather large, usually situated nearly at midlength of head's lateral surface. Antenna 12-segmented. Petiole trapezoidal in dorsal view, broadly attached to first gastral segment, nearly $40 \%$ as wide as first gastral segment. Forewing with closed cells $1+2 \mathrm{r}, 3 \mathrm{r}, \mathrm{rm}$ and mcu. Icu $<1.4$.

Species included: Casaleia inversa (DLussky, 1981) (ChonTuz, Kirgizia, Middle Miocene), and C. eocenica DLussKy \& Wedmann, 2012 (Messel, Germany, Middle Eocene).

\section{Casaleia longiventris (HEeR, 1849), n. comb.} Fig. 13A

1849 Formica longiventris HeER, 1849, p. 123, pl. 9, fig. 6a-c (P).

1907 Formica longiventris HeER, 1849. - HandLIRsch, p. 864.

1995 Formica longiventris HeER, 1849. - Bolton, p. 197.

Studied material: Lectotype of Formica longiventris UMJG\&P no. 77.584 (designated here, ).
Diagnosis: $C$. longiventris differs from $C$. inversa and $C$. eocenica in its size (body length is $6.5 \mathrm{~mm}$ in $C$. inversa, and $4.9 \mathrm{~mm}$ in C.eocenica), and in its more elongate mesosoma.

Description: Gyne. BL $10 \mathrm{~mm}$. Head longer than wide. Eyes oval. With head in full-face view the eyes at the midlength of the side of the head.. Mesosoma elongate, nearly as wide as head, and 1.8 times as long as wide. Scutum 1.3 times as wide as long. Scutellum 1.6 times as wide as long. Petiole twice as wide as long, broadly attached to first gastral tergite. First gastral tergite 1.5 times as long as second and nearly as wide as second. Constriction between first and second gastral segments distinct.

Measurements of holotype, in $\mathbf{m m}: \mathrm{AL}=2.9, \mathrm{AW}=1.6$, $\mathrm{HL}=1.6, \quad \mathrm{HW}=1.5, \quad \mathrm{Sct} \mathrm{L}=1.1, \quad \mathrm{Sct} W=1.4, \quad \mathrm{Sctl} \mathrm{L}=0.6$, SctlW=1.0, PtL=0.5, PtW=1.0, HWL=6.4, GL=5.2.

Remarks: Heer (1849) described Formica longiventris from seven specimens. According to his description, this species differs from all of the other species of Formica in its long and narrow gaster. We found in the collection of UMJG\&P two specimens of this species that were identified by HEER and labelled as syntypes. Specimen UMJG\&P

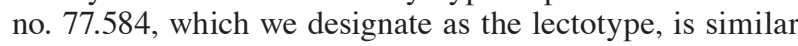
to the description in size and proportions $(\mathrm{BL}=9.9, \mathrm{HL}=2.2$, $\mathrm{HW}=1.9, \mathrm{AL}=3.0, \mathrm{AW}=2.2$, $\mathrm{GL}=5.5, \mathrm{FWL}=8.8$ ). The elongate gaster with a distinct constriction between the first and second gastral segments and the petiole broadly attached to the gaster give evidence that this ant belongs to the subfamily Amblyoponinae, and the position of the eyes and shape of the petiole give evidence that it belongs to the genus $\mathrm{Ca}$ saleia. The second specimen (UMJG\&P no. 77.500) cannot be placed in this species, because it has a compact, short oval gaster $(\mathrm{GL}=3.8)$.

\section{Subfamily Ponerinae LePeletier de Saint-Fargeau, 1835 \\ Morphogenus Ponerites Dlussky \& RASNITSYN, 2002.}

Type species: Ponerites eocenicus Dlussky \& Rasnitsyn, 2002 , by original designation.

Diagnosis: Fossil ants not well enough preserved to fit orthotaxa, with the following combination of traits: Waist consisting of one segment (petiole) of various shape, narrowly attached to first gastral (III abdominal) segment. Gaster usually with constriction between first and second gastral (III and IV abdominal) segments; second gastral (IV abdominal) tergite and sternite subequal, gastral apex not directed downward; sting well developed. Gyne and worker antennae geniculate; male antennae with short scape, often filiform. Gyne and worker mandibles triangular with denticulate masticatory margin. Denticles or spines on head, mesosoma and waist absent. Forewing with closed cells $1+2 \mathrm{r}, 3 \mathrm{r}, \mathrm{rm}$ and $\mathrm{mcu}$. Icu< $<1.45$.

Species included: Ponerites eocenicus, P. coloradensis 


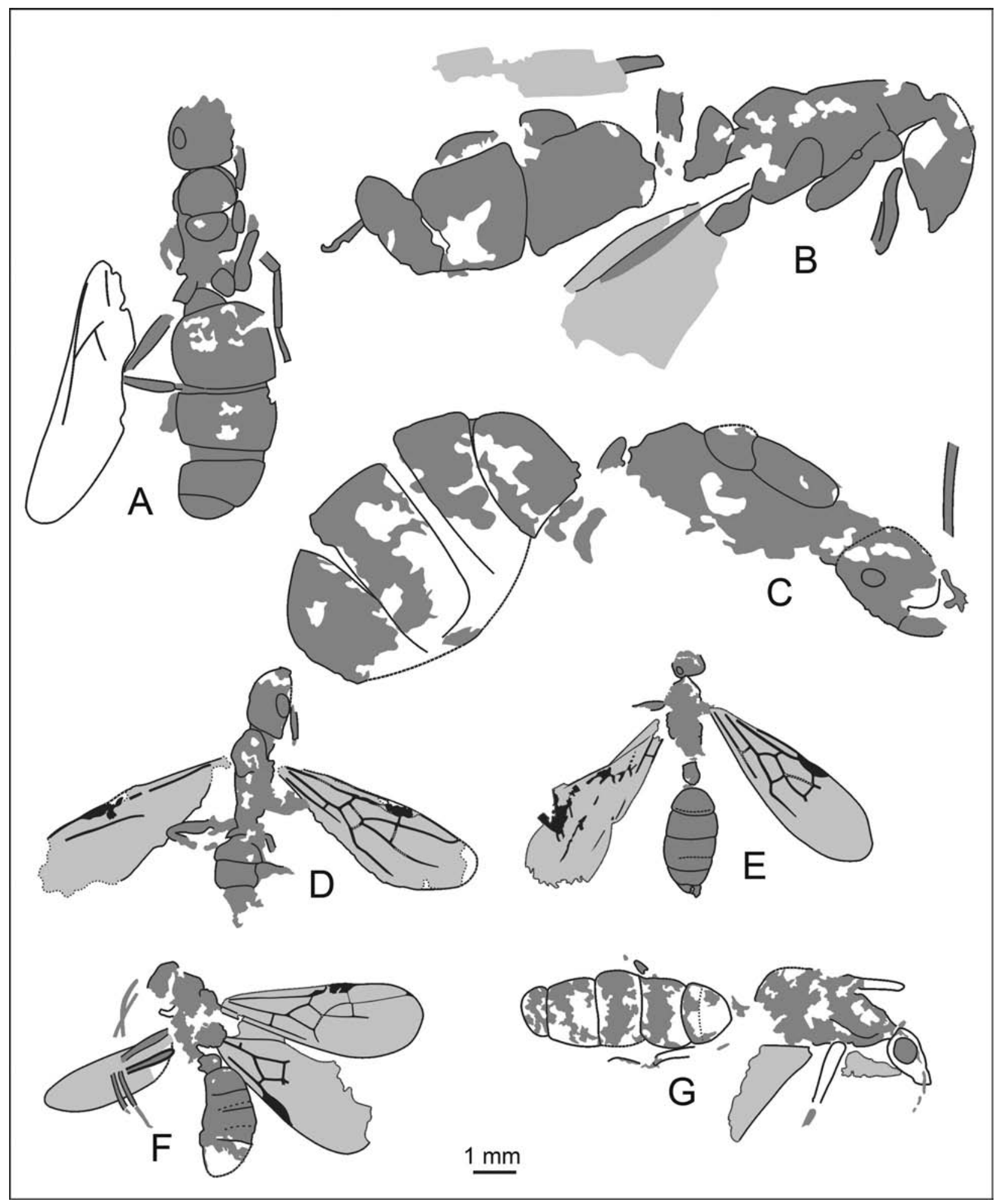

Fig. 13. Species of poneromorph subfamilies. A - Casaleia longiventris (HeER, 1849), lectotype of Formica longiventris HeEr, 1849, UMJG\&P no. 77.584 (9); B - Ponerites elongatus (HeEr, 1867), lectotype of Poneropsis elongata HeER, 1867 NHMW no. 1852.XXIX.33 (\$); C - Ponerites gracilior nom. nov., lectotype of Formica gracilis HeER, 1867, UMJG\&P no. 77.544 (\$); D - Ponerites oblongiceps sp. nov., holotype GBA no. 2009/016/0515 (\$); E - Ponerites atavinus (HeER, 1849), holotype of Formica atavina HeER, 1849, UMJG\&P no. 77.582 (ơ); F - Ponerites tenuis (HeER, 1867), lectotype of Poneropsis tenuis HeER, 1867, UMJG\&P no. 77.589 (ơ); G - Ponerites nitidus (HeER, 1849). Neotype of Ponera nitida HEER, 1849, UMJG\&P no. 77.622 ( ( )). 
and $P$. hypoponeroides (Dlussky \& Rasnitsyn, 2002) from the Middle Eocene of the Green River Formation; P. umbrus (Popov, 1932) from the Middle Miocene of the North Caucasus; and six species described below. Evidently, some European Miocene and Oligocene ants described as Ponera also belong to this morphogenus.

Ponerites elongatus (HEER, 1867), n. comb. Fig. 13B

1867 Poneropsis elongata HeER, p. 19, pl. 1, fig. 21 (\%).

1907 Poneropsis elongata Heer, 1867. - Handlirsch, p. 881.

1964 Formicidae incertae generis. - TAYLOR, p. 138.

1995 Poneropsis elongata HeER, 1867. - Bolton, p. 363.

Studied material: Lectotype NHMW no. 1852.XXIX.33 (\%)

Diagnosis: Differs from all known species of the genus in its larger size (in the other species, body length is smaller than $10 \mathrm{~mm}$ ). Differs from $P$. gracilior (described below) in its long first gastral segment and triangular shape of the petiole.

Description: Gyne. BL $16.1 \mathrm{~mm}$. Mesosoma elongate. Scutum weakly convex in lateral view. Propodeum angulate in side view; propodeal dorsum shorter than declivity. Petiole with node, triangular in side view, nearly as long as high. First gastral segment longer than second. Constriction between first and second gastral segments present.

Measurements of lectotype, in mm: $\mathrm{AL}=4.55, \mathrm{HL}=2.8$, $\mathrm{PtL}=\mathrm{PtH}=1.5$.

Remarks: Heer (1867) described Poneropsis elongata from five specimens, of which only one has been preserved; we designate this specimen as the lectotype. It is not very similar to HeER's figure, but doublessly belongs to the subfamily Ponerinae and is similar in size to the measurements provided by HeER (BL=15.0, HL=2.7). Since no diagnostic characters distinguishing the genera of this subfamily are visible in the compression fossil, we place this specimen in the formal genus Ponerites.

\section{Ponerites gracilior n. nom.}

Fig. 13C

1867 Formica gracilis HeER, p. 7, pl. 1, fig. 3a, b (\$), junior homonym of Formica gracilis FABRICIUS 1804, p. 405.

1907 Formica gracilis HeER, 1867. - HandLIRsCh, p. 864.

1995 Formica gracilis HeER, 1867. - Bolton, p. 196.

Studied material: Lectotype of Formica gracilis HeER UMJG\&P no. 77.544 (designated here, 9 , figured in HEER, 1867, pl. 1, fig. 3b).
Diagnosis: Differs from the majority of known species of the genus in its larger size, and shape of the anterior margin of the clypeus. Differs from P. elongatus (described above), which is also large, in its short first gastral segment and in the petiole shape.

Description: Gyne. BL $17 \mathrm{~mm}$. Head longer than wide, with parallel sides, rounded occipital corners, and straight occipital margin. Anterior clypeal margin very convex. Eyes oval; with head in full-face view the eyes slightly behind the midlength of the side of the head..Gena length greater than maximum eye diameter. Scape protruding beyond occipital margin. Mandibular bases set far apart. Mesosoma elongate. Scutum slightly convex in lateral view, not overhanging pronotum. Propodeum angulate in lateral view, propodeal dorsum shorter than declivity. Petiole with thick scale. Helcium protruding from very low down on the anterior face of first gastral segment. First gastral segment longer than second. Constriction between first and second gastral segments weak, but distinct.

Measurements of lectotype, in mm: $\mathrm{AL}=6.2, \mathrm{HL}=2.3$, $\mathrm{HW} \sim 2.0, \mathrm{ED}=0.55$.

Remarks: Heer (1867) described this species from two specimens, one of which, depicted in pl. 1, fig. $3 \mathrm{~b}$, has been preserved, and we designate it as the lectotype. Formica gracilis HeER, 1867 is a junior homonym of Formica gracilis FABRICIUS, 1804 (= Pseudomyrmex gracilis). Therefore, we replace the specific epithet with gracilior.

The presence of a constriction between the first and second gastral segments, the position of the helcium, and the general habitus of this ant give evidence that it doubtlessly belongs to the subfamily Ponerinae. It is outwardly similar to some members of the genus Leptogenys Roger, but key characters that would allow placement of this species in any of the known genera are not visible in the impression. Therefore, we place it in the formal morphogenus Ponerites.

\section{Ponerites oblongiceps n. sp. \\ Figs. 13D, 16C}

Etymology: Oblongiceps is the Latin word for "oblongheaded".

Studied material: Holotype GBA nos. 2009/016/0515 ( $\%$, identified as Formica longaeva) and 2009/016/0543 (counterpart of the same specimen, identified as Formica occultata). Paratype GBA no. 2009/016/0672 (\%).

Diagnosis: Differs from all known species of the genus in the elongate head with a concave occipital margin and large oval eyes.

Description: Gyne. BL 6-7 mm. Head longer than wide, with parallel sides, distinct occipital corners, and concave occipital margin. Eyes oval, large; with head in full-face view the eyes in front of the midlength of the side of the head.. Genae shorter than maximum eye diameter. Scape reaching occipital margin. Middle joints of funiculus wider 
than long. Mesosoma elongate, nearly as wide as head. Scutum weakly convex in lateral view, not overhanging pronotum. Propodeum gradually rounded. Petiole with high scale. Legs rather short and thick. First gastral tergite nearly as long as second. Helcium protruding from very low down on anterior face of first gastral segment, the latter with a high vertical anterior face above the helcium. Constriction between first and second gastral segments distinct. Forewing with closed cells $1+2 \mathrm{r}, 3 \mathrm{r}$, rm and mcu; cell rm quadrangular, 1.8 times as long as wide; cell mcu pentagonal, nearly twice as long as wide; vein section $1 \mathrm{M}$ a little longer than $1 \mathrm{RS}$. Icu $=1.45$.

Measurements, in mm: Holotype: $\mathrm{AL}=2.4, \mathrm{HL}=1.3$, $\mathrm{HW}=1.0, \mathrm{ED}=0.6, \mathrm{FWL}=5.3$. Paratype: $\mathrm{BL}=6.4, \mathrm{AL}=2.3$, $\mathrm{HL}=1.3$.

Remarks: The relatively ventral position of the helcium, constriction between the first and second gastral segments, and forewing venation clearly show that this species belongs to the subfamily Ponerinae. Since diagnostic characters used to distinguish between the genera of this subfamily are not visible in the imprint, we place this species in the form genus Ponerites.

\section{Ponerites atavinus (HEER, 1849) n. comb.} Fig. 13E

1849 Formica atavina HeER, p. 143, pl. 11, fig. 10 (o').

1867 Formica atavina HeER, 1849. - HeER, p. 18.

1907 Formica atavina HeER, 1849. - HANDLIRSCH, p. 864.

1995 Formica atavina HeER, 1849. - Bolton, p. 191.

Studied material: Holotype UMJG\&P no. 77.582 ( $0^{\text {, f fig- }}$ ured by HeER, 1849: pl 11, fig. 10).

Diagnosis: Males of Ponerites have not been described previously. $P$. atavinus differs from $P$. nitidus (described below) in its smaller size and relatively small eyes, and from $P$. tenuis in its elongate petiole and large cell mcu in the forewing.

Description: Male. Body length $5.6 \mathrm{~mm}$. Head small, with rounded occipital angles and straight occipital margin. Eyes rather small, oval; with head in full-face view the eyes behind the midlength of the side of the head. Mesosoma elongate. Petiole nodiform, 1.5 times as long as wide. Gaster elongate, with distinct constriction between first and second gastral segments. Forewing with closed cells $1+2 \mathrm{r}$, rm, mcu, and evidently $3 \mathrm{r}$; cell $\mathrm{rm}$ triangular; cell mcu quadrangular, large, nearly twice as long as wide; vein section $1 \mathrm{M}$ about 2.5 times as long as $1 \mathrm{RS}$. Icu=1.35.

Measurements of holotype, in mm: $\mathrm{AL}=1.8, \mathrm{HW}=0.7$, $\mathrm{PtL}=0.55, \mathrm{PtW}=0.37, \mathrm{FWL}=5.2$.

Remarks: HeER described this species from a single specimen, which has been preserved in the UMJG\&P collection. MAYr (1867) examined two speimens indentified by HeER, and placed them, judging by habitus, in the subfamily Myrmicinae. However, HandLIRSCH (1907) provisionally left this species in the genus Formica. The position of the crossvein cu-a in the forewing and presence of a constriction between the first and second gastral segments clearly indicate that the holotype of this species belongs to the subfamily Ponerinae. Since diagnostic characters used to distinguish between the genera of this subfamily are not visible in the compression fossil, we place this species in the form genus Ponerites.

\section{Ponerites tenuis (HeER, 1867), n. comb.} Fig. $13 \mathrm{~F}$

1867 Poneropsis tenuis Heer, p. 22, pl. 2, fig. 1 (o').

1867 Ponera? tenuis (HeER, 1867). - MAYr, p. 57.

1907 Ponera? tenuis (HeER, 1867). - Handlirsch, p. 880.

1995 Poneropsis tenuis Heer, 1867. - Bolton, p. 363.

Studied material: Lectotype of Poneropsis tenuis UMJG\&P no. 77.589 (designated here, ơ, figured by HeER, 1867, pl. 2, fig. 1). Other specimens identified by HeER as Ponera tenuis: NHMW no. 1852.XXIX.36 (20').

Diagnosis: Differs from the male $P$. atavinus (described above) in its short petiole and trapezoid cell mcu in the forewing, and from the male P. nitidus (described below) in its smaller size.

Description: Male. BL 6-7 mm. Antennae long, filiform. Mesosoma elongate. Scutum weakly convex in lateral view. Petiole nodiform, shorter than high, with ventral lobe and node rounded in lateral view. Helcium protruding from ventral position on anterior face of first gastral segment, the latter rounded in side view. Legs rather long. Gaster with constriction between first and second segments. Forewing with closed cells $1+2 \mathrm{r}, 3 \mathrm{r}$, rm and mcu; cell rm triangular, without peduncle, twice as long as wide; cell mcu trapezoidal; vein section $1 \mathrm{Cu} 1.7$ times as long as $\mathrm{RS}+\mathrm{M}$; section $1 \mathrm{M}$ about 2.5 times as long as 1RS. Icu=1.4.

Measurements, in mm: UMJG\&P no. 77.589 (lectotype): $\mathrm{AL}=2.2, \mathrm{FWL}=5.0, \mathrm{PtL}=0.4$, $\mathrm{PtH}=0.5$; NHMW no. 1852.XXIX.36a: $\mathrm{AL}=2.4, \mathrm{FWL}=5.8$; NHMW no. 1852. XXIX.36b: $\mathrm{AL}=2.8, \mathrm{FWL}=5.8$.

Remarks: Heer (1867) described this species from seven specimens, one of which (depicted by HEER) has been preserved, and we designate it as the lectotype. Two other specimens identified by HeER, preserved closely within the same piece of rock, probably do not belong to the type series. They are on the whole similar to the lectotype, but are a little larger. MAYR (1867) examined three specimens identified by HEer, and came to the conclusion that two of them belong to the subfamily Ponerinae, but differ in venation from each other and from HEER's description, and provisionally placed them in the genus Ponera. We have failed to find these specimens in the studied collections.

The lectotype of $P$. tenuis is doubtlessly a male belonging to Ponerinae. Since diagnostic characters used to distin- 
guish between the genera of this subfamily are not visible in the compression fossil, we place this species in the form genus Ponerites.

\section{Ponerites nitidus (HEER, 1849), n. comb.} Fig. 13G

1849 Ponera nitida Heer, p. 149, pl. 12, fig. 4 (ơ, described as P).

1867 Poneropsis nitida (HEer, 1849). - HeER, p. 20.

1867 Hypoclinea nitida (HEER, 1849). - MaYr, p. 57.

1878 Dolichoderus nitidus (HEer, 1849). - Forel, p. 386.

1907 Dolichoderus nitidus (HeER, 1849). - Handlirsch, p. 870.

1964 Poneropsis nitida (HeER, 1849). - TAYLOR, 1964, p. 138.

1994 Dolichoderus nitidus (Heer, 1849). - Shattuck, p. 59.

1995 Dolichoderus nitidus (Heer, 1849). - Bolton, p. 175.

Studied material: Neotype of Ponera nitida UMJG\&P no. 77.622 (designated here, $0^{7}$ ).

Diagnosis: Differs from the males of P. atavinus and P.tenuis (described above) in its larger size.

Description: Male. BL $9.8 \mathrm{~mm}$. Head elongate with large, round eyes. Mesosoma elongate. Propodeum rounded in lateral view. Petiole not preserved. Gaster with constriction between first and second segments. First gastral tergite a little longer and narrower than second. Wing venation not preserved.

Measurements of neotype, in mm: $\mathrm{AL}=3.4, \mathrm{HL}=1.2$, $\mathrm{ED}=0.6$.

Remarks: Heer (1849) described this species from one specimen, which has not been preserved. He described it as a gyne, but judging by the number of gastral segments shown in the figure, the specimen was a male, rather than a gyne. Subsequently, he found another specimen, which has been preserved in the UMJG\&P collection (HEER 1867). This specimen is labelled as a syntype, but formally it cannot be considered a syntype, and we designate it as the neotype. MAYR (1867) examined one specimen identified by HeER and identified it as a male of Hypoclinea. This specimen has not been preserved. FOREL (1878) did not see this specimen, but placed it in the genus Dolichoderus (a senior synonym of Hypoclinea).

Although the neotype is poorly preserved, the general habitus and presence of a constriction between the first and second gastral segments allow placement in the subfamily Ponerinae and the form genus Ponerites.

Subfamily Myrmicinae LePeletier de SAint-FARgEaU, 1835

Morphogenus Paraphaenogaster DLussky, 1981
Type species: Paraphaenogaster microphthalma DLussKY, 1981, by original designation.

Diagnosis (for compression fossils): Waist with two segments (petiole and postpetiole). Forewing with closed cells $1+2 \mathrm{r}$ and $\mathrm{mcu}$, and $\mathrm{rm}$; cell $3 \mathrm{r}$ open at apex; apical sections of veins RS and M leaving cell 1+2r+rm separately.

Species included: Type species from Vishnevaya balka, Stavropol, Russia; Middle Miocene. We found forewings with such venation in Bembridge, UK (Late Eocene or Early Oligocene), Bol'shaya Svetlovidnaja, Maritime Province, Russia (Early Oligocene), Rott, Germany (Late Oligocene), Enspel, Germany (Late Oligocene), and Willershausen, Germany (Pliocene), however, these species remain undescribed. Myrmica aemula HeER, 1849 from Parschlug, Austria (Miocene), Myrmica macrocephala HeER, 1849, M. rugiceps Heer, 1849, M. tertiaria HeER, 1849 from Oeningen, Germany (Middle Miocene), Carebara bohemica (NovÁK, 1877) from Krottensee, Czechia (Miocene), Aphaenogaster shanwangensis (Hong, 1984), A. lapidescens ZHANG, 1989 and A. paludosa ZHANG, 1989 from Shanwang, China (Middle Miocene) are similar in venation and might also belong to this morphogenus.

Remarks: Similar venation is characteristic of some Myrmicinae: Pheidolini (part of Aphaenogaster MAYR) and Solenopsidini (Solenopsis Westwood, Carebara Westwood).

Paraphaenogaster tertiaria (HEER, 1849), n. comb. Figs. 14A-B, 18D

1849 Myrmica tertiaria radobojana HeER, p. 159, pl. 13, fig. 1 (क).

1867 Myrmica tertiaria HeER, 1849 - Heer, p. 30.

1867 Myrmica bicolor Heer, p. 31, pl. 2, fig. 11 (†) (syn. by MAYr, 1867).

1867 (Myrmicinae) tertiaria (HEER, 1849). - MAYr, p. 58

1893 Myrmica tertiaria Heer, 1849. - Dalla Torre, p. 117.

1907 (Myrmicidae) tertiaria radobojana (HeER, 1849). HANDLIRSCH, p. 878.

1995 Myrmica tertiaria Heer, 1849. - Bolton, p. 284.

Studied material: Holotype of Myrmica bicolor UMJG\&P no. 77.624 (\$); Specimen GBA no. 2009/016/0603 (?ㅇ) identified by HeER as Attopsis nigra.

Diagnosis: Gynes of Paraphaenogaster have not been described previously. P. tertiaria differs from $P$. jurinei (described below) in its larger size and head shape (head 1.25 times longer than wide in P.tertiaria, and 2 times in $P$. jurinei).

Description: Gyne. BL 10-13 mm. Head 1.25 times as long as wide, with parallel sides and rounded occipital margin, without occipital angles. Anterior clypeal margin notched medially. Eyes oval, with head in full-face view the eyes distinctly behind the midlength of the side of the head; ge- 


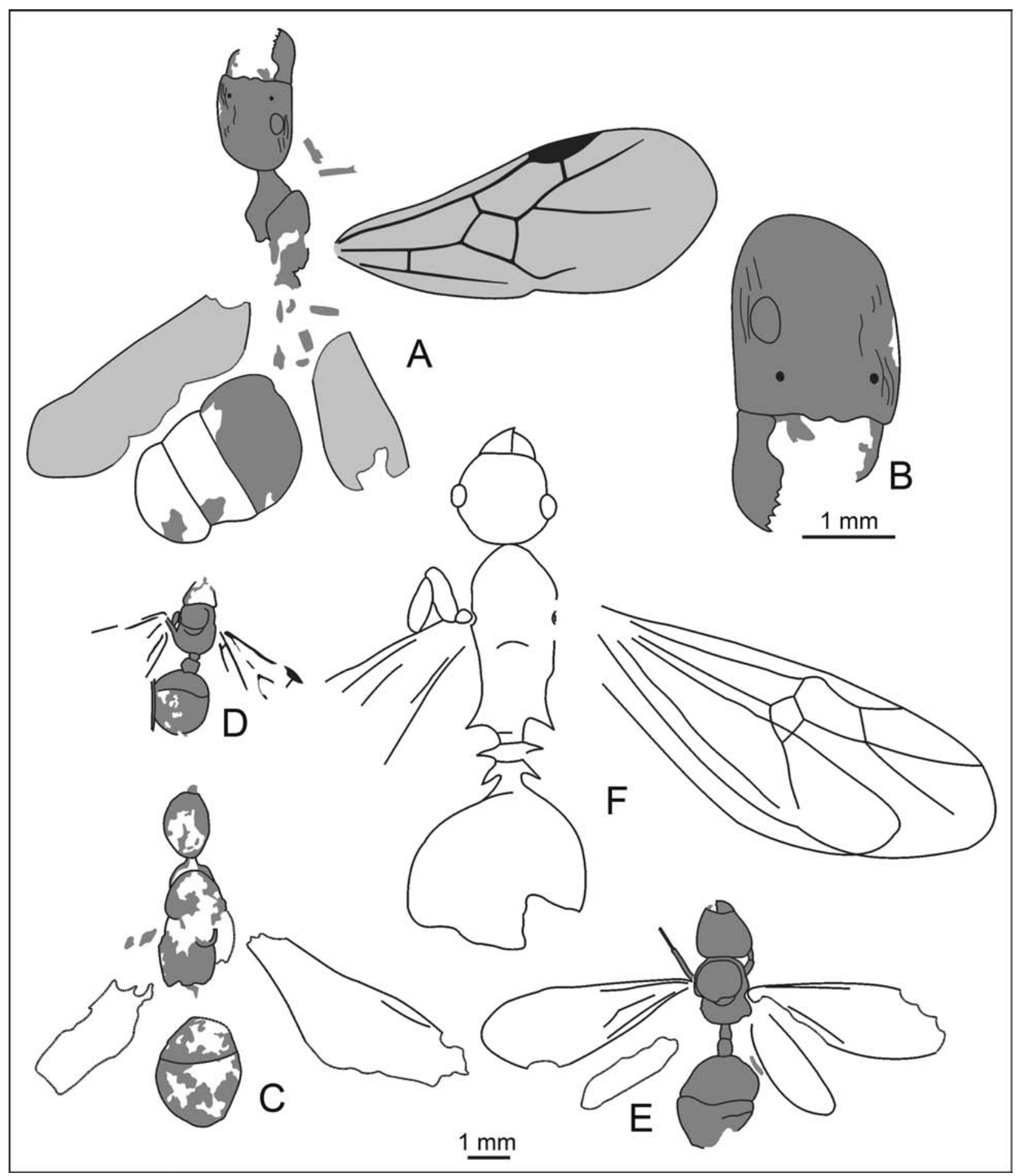

Fig. 14. Species of the subfamily Myrmicinae. A-B - Paraphaenogaster tertiaria (HeER, 1849); A - holotype of Myrmica bicolor HeER, 1867, UMJG\&P no. 77.624 (\$); B - head of the same specimen; C - Paraphaenogaster jurinei (HEER, 1849), neotype of Myrmica jurinei HeER, 1849, UMJG\&P no. 211032 (\$); D - Myrmecites pusillus (HeER, 1849), neotype of Myrmica pusilla HeER, 1849, NHMW no. 1852.XXIX.41 (\$); E - Myrmecites latus, sp. nov., holotype NHMW no. 2014/0130/0001 (९); F - Lonchomyrmex freyeri (HeER, 1867) ( $($, from MAYR 1867). 
nal length greater than maximum eye diameter. Mandible triangular, with six acute teeth. Mesosoma elongate, narrower than head. Scutum longer than wide. Posterior margin of propodeum and waist not preserved. Gaster oval. Head with longitudinal rugae. Forewing as in genus. Cell mcu trapezoid. Section 1M about twice as long as 1RS. Icu=2.0.

Measurements, in mm: UMJG\&P no. 77.624: $\mathrm{AL}=3.7$, $\mathrm{HL}=2.25, \mathrm{HW}=1.8, \quad \mathrm{ED}=0.5, \quad \mathrm{FWL}=9.3 ; \mathrm{GBA}$ no. 2009/016/0603: AL=3.6, FWL>7.9.

Remarks: MAYR (1867) examined two specimens identified by HEer as Myrmica tertiaria, and one specimen identified by HeER as M. bicolor, and came to the conclusion that they were conspecific. We have failed to find in the studied collections any specimens identified by HeER as M. tertiaria, but have found the holotype of $M$. bicolor. HeER considered the two-colour pattern of the gaster (black first tergite and pale subsequent tergites) a distinguishing character of $M$. bicolor, but the preserved coloration of compression fossils cannot be considered a diagnostic character. Moreover, it is clearly visible in the imprint of the holotype of $M . b i$ color that on the first gastral tergite carbonised chitin has been preserved, whereas on the other tergites no chitin has been preserved, which explains the two-color pattern of the gaster. Since the size, proportions, and wing venation of $M$. tertiaria and M. bicolor (judging by HEER's descriptions and figures) are similar, we believe that it is reasonable to follow MAYR's synonymisation. The holotype of M. bicolor is outwardly very similar to a gyne of Aphaenogaster, but since the diagnostic characters of this genus are not visible in the compression fossil, we prefer to place it in the form genus Paraphaenogaster. Comparison with P. microphthalma, the only known species of this genus, is impossible, because that species was described from a male.

\section{Paraphaenogaster jurinei (HEER, 1849), n. comb.} Fig. 14C

1849 Myrmica jurinei HeER, p. 163, pl. 13, fig. 8 (\%).

1867 Myrmica concinna HeER, p. 32, pl. 2, fig. 13 (\$), n. syn.

1867? Myrmica jurinei HeER, 1849. - MAYR, p. 59.

1907 Myrmica concinna Heer, 1867. - Handuirsch, p. 875 , n. syn.

1907? Myrmica jurinei Heer, 1849. - HandliRsch, p. 875.

1995 Myrmica concinna HeER, 1867. - Bolton, p. 278, n. syn.

1995 Myrmica jurinei Heer, 1849. - Bolton, p. 280.

Studied material: Neotype of Myrmica jurinei UMJG\&P no. 211032 ( $\$$, identified by HEER as Attopsis anthracina). Specimen NHMW no. 1852.XXIX.40 ( $\%$, identified by HeER as Myrmica jurinei).

Diagnosis: Differs from $M$. tertiaria in its smaller size and head shape (head 1.25 times longer than wide in P.tertiaria, and 2 times in $P$. jurinei).
Description: Gyne. BL 7.3-8.3. Head nearly twice as long as wide, with convex sides and rounded occipital margin, without occipital corners. Mesosoma wider than head, elongate, nearly twice as long as wide. Scutum wider than long. Propodeum without spines or teeth. Postpetiole longer than high. Gaster oval.

Measurements, in mm: Neotype: $\mathrm{BL}=8.3, \mathrm{AL}=3.1$, $\mathrm{AW}=1.5, \mathrm{HL}=1.5, \mathrm{HW}=1.1, \mathrm{FWL}=7.1$; NHMW no. 1852 . XXIX.40: $\mathrm{BL} \sim 7.3, \mathrm{AL}=2.6, \mathrm{FWL}=7.5$.

Remarks: HeER (1849) described M. jurinei from a single specimen. He considered this specimen to be a male, since he believed he had found five gastral segments. However, judging by the general habitus and shape of the gaster, the specimen shown in the figure was most probably a gyne. MAYR (1867) examined three specimens identified by HEeR as $M$. jurinei. One of them was outwardly similar to $M y r$ mica, but its wing venation has not been preserved. The two others clearly belonged to other species. We have failed to find in the studied collections the holotype of this species, but found two specimens of identical size and body shape. Specimen NHMW no. 1852.XXIX.40, identified by HEER as $M$. jurinei, is poorly preserved, but its waist is clearly two-segmented. The second specimen (which we designate as the neotype), identified by HeER as Attopsis anthracina, cannot be placed in this species, because it is considerably larger ( $\mathrm{AL}=3.1$, whereas in $A$. anthracina, according to the description, $\mathrm{AL}=1.6)$. The waist of this specimen has not been preserved, but the position of the gaster and the longer first gastral tergite give evidence that the waist was twosegmented. Unfortunately, the wing venation has not been preserved in any of these two specimens. Judging by HEER's description and figure, $M$. jurinei had wing venation typical of Paraphaenogaster.

HeER described Myrmica concinna from two specimens, which, as well as any other specimens identified as $M$. concinna, we have failed to find in the studied collections. MAYr (1867) examined two specimens of this species identified by HeEr, but they were poorly preserved, and he could not place them in any genus. Judging by HEER's figure and description, this species belongs to the form genus Paraphaenogaster and is a junior synonym of Myrmica jurinei.

\section{Morphogenus Myrmecites DLuSSKy \& RASNITSYN, 2003}

Type species: Myrmecites rotundiceps DLuSSKY \& RASNITSYN, 2003, by original designation.

Diagnosis: Ant compression fossils with two-segmented and short waist (less than half as long as gaster and less than one third as long as mesosoma), petiole sessile, and postpetiole narrowly attached to gaster, which cannot be identified more precisely.

Species included: Type species described from the Green River Formation (Middle Eocene), and species re-described below. 
Myrmecites pusillus (HeER, 1849), n. comb. Fig. 14D

1849 Myrmica pusilla Heer, p. 164, pl. 13, fig. 9 (described as ơ).

1867 Myrmicapusilla Heer, 1849.-HeER,p.32,pl.2, fig. 14.

1867 Cremastogaster pusilla (HeER, 1849). - MAYr, p. 59.

1907 Cremastogaster pusilla (HeER, 1849). - HandLIRSCH, p. 873.

1995 Crematogaster pusilla (Heer, 1849). - Bolton, p. 160.

Studied material: Neotype NHMW no. 1852.XXIX.41 ( designated here).

Diagnosis: Similar in the structure of the waist to M. rotundiceps, and differs from latter in its shorter and wider mesosoma (in $M$. rotundiceps the mesosoma is twice as long as wide).

Description: Gyne. BL $3.8 \mathrm{~mm}$. Head nearly as wide as mesosoma. Mesosoma 1.4 times as long as wide. Propodeum without spines or teeth. Petiole sessile, 1.4 times as wide as long. Postpetiole 1.6 times as wide as petiole and 1.25 times as wide as long. Gaster rounded. Wing venation not preserved.

Measurements of neotype, in mm: $\mathrm{AL}=1.2, \mathrm{AW}=0.85$, $\mathrm{PtL}=0.18, \mathrm{PtW}=0.25, \mathrm{PptL}=0.32, \mathrm{PptW}=0.40$.

Remarks: Heer (1849) described Myrmica pusilla from a single specimen, which is probably lost. We have found in the studied collections only one specimen identified by HeER, which we designate as the neotype. The measurements of this specimen are similar to those provided by HeER in his description ( $\mathrm{BL}=3.8, \mathrm{AL}=1.1, \mathrm{AW} 0.8$ ). This specimen is probably different from the one identified by MAYr (1867) as Crematogaster. The specimen examined by MAYR had an identifier number 92, whereas the specimen examined by us has an old identifier number 93 . Since this specimen has a two-segmented waist, it doubtlessly belongs to the subfamily Myrmicinae. However, the impression is poorly preserved, and diagnostic characters used to distinguish between the genera of this subfamily cannot be discerned; therefore, we place it in the form genus Myrmecites.

\section{Myrmecites latus n. sp.}

Figs. 14E, 18C

Etymology: Latus is the Latin word for "wide".

Studied material: Holotype NHMW no. 2014/0130/0001, with label "Jahr d. Acq. 1890. Formicidae (HandL.). Miocaen. Radoboj. Dr. KatholiczKY did." (P). Paratype NHMW no. 1852.I.1012 (\%).

Diagnosis: The new species is similar to M. pusillus, but clearly differs from it in size, with a shorter mesosoma, and elongate segments of the waist.
Description: Gyne. BL ca. $6 \mathrm{~mm}$. Head 1.2 times as wide as long, with convex sides, rounded occipital corners and weakly concave occipital margin. Anterior margin of clypeus concave. Mandibles triangular. Mesosoma nearly as wide as head, 1.2 times as long as wide. Scutum large, 1.2 times as wide as long. Dorsum of mesosoma convex in side view. Propodeum without spines or teeth, angular in side view. Petiole 1.3 times as long as wide, broader posteriorly than anteriorly. Postpetiole 1.3 times as wide as petiole and 1.3 times as long as wide. Gaster oval. Wing venation not preserved.

Measurements, in mm: Holotype: $\mathrm{BL}=6.1, \mathrm{AL}=1.7$, $\mathrm{AW}=1.3, \mathrm{HL}=1.2, \mathrm{HW}=1.35, \mathrm{SctL}=0.9, \mathrm{SctW}=1.1, \mathrm{PtL}=0.35$, $\mathrm{PtW}=0.27, \mathrm{PptL}=0.44, \mathrm{PptW}=0.34, \mathrm{FWL}=5.6$. Paratype: $\mathrm{BL}=6.2, \mathrm{AL}=2.0, \mathrm{FWL}=6.3$

Remarks: The specimen we designate as the holotype was identified as Formica demersa, but the identification is clearly not HeER's, since the material was received by the museum in 1890, and HeER died in 1883. F. demersa was described from Oeningen, but it has never been reported from Radoboj.

\section{Genus Lonchomyrmex MAYR, 1867}

Type species: Formica freyeri HeER, 1867, by monotypy.

Diagnosis (modified from MAYR 1867, terminology corrected): Gyne. Mandibles depressed, not wide, with masticatory margin oblique and dentate and apical tooth strongly protruding. Head rounded, wider than long (excluding mandibles). Eyes rather small, convex, situated approximately at midlength of lateral surface of head. Mesosoma twice as long as wide; propodeum likely with pair of spines set far apart. Waist two-segmented; petiole with pair of long lateral spines directed laterally; postpetiole with pair of short lateral spines slightly directed posterad. Gaster rounded. Forewing with closed cells $1+2 \mathrm{r}$, $3 \mathrm{r}$ and mcu; cell $\mathrm{rm}$ absent; free branches $5 \mathrm{RS}$ and $4 \mathrm{M}$ leave cell $1+2 \mathrm{r}$ from common expanded junction.

\section{Lonchomyrmex freyeri (HEER, 1867)}

Fig. 14F

1867 Formica freyeri HeER, p. 10, pl. 1, fig. 9 (\%).

1867 Lonchomyrmex freyeri (HeER, 1867). - MAYR, p. 61, fig. 12.

1907 Lonchomyrmex freyeri (HEER, 1867). - HANDLIRSCH, p. 878 ,

1995 Lonchomyrmex freyeri (HeER, 1867). - Bolton, p. 248.

Description (from MAYR 1867): Gyne. With characters of genus. Body length $12.5 \mathrm{~mm}$, forewing length $11.5 \mathrm{~mm}$.

Remarks: HeER described this species from a single specimen. MAYr found two specimens identified as Formica 
freyeri, one of which, judging by the similarity between the figures of HeER and MAYR, was the holotype. MAYR found that this ant actually belonged to the subfamily Myrmicinae and described a new genus. We have failed to find this species in the studied collections.

\section{Species of unclear status and placement \\ Formicidae incertae generis \\ (Formicidae) oculata HeER, 1849 n. comb.}

Fig. 15A

1849 Formica oculata HeER, p. 143, pl. 10, fig. 9d (ơ).

1867 Formica oculata HeER, 1849. - HeER, p. 17, pl. fig. $18\left(\sigma^{7}\right)$.

1907 Formica oculata HeER, 1849. - Handlirsch, p. 865.

1995 Formica oculata Heer, 1849. - Bolton, p. 200.

Holotype: UMJG\&P no. 77.646d (\%).

Remark: HeER described this species from a single specimen, which he considered to be male. Actually, it is a poorly-preserved compression fossil of a gyne. The imprint of the holotype is so poorly preserved that we cannot place it in any known species or describe as a valid species. Therefore, we suggest treating Formica oculata as Formicidae incertae generis.

(Formicidae) obtecta HeER, 1849 n. comb. Fig. 15B

1849 Formica obtecta HeER, p. 123, pl. 9, fig. 7, pl. 10, fig. 9c, pl. 11, fig. 14f (\%).

1907 Formica obtecta Heer, 1849. - HandliRsch, p. 865.

1995 Formica obtecta HeER, 1849. - Bolton, p. 200.

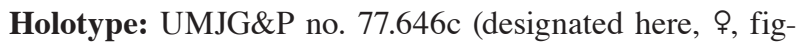
ured by Heer, 1849: pl. 9, fig. 7, pl. 10, fig. 9c)

Remarks: HEER mentions in his description two specimens: a wingless gyne (designated here as the holotype) and a gaster. Apparently, the gyne should be considered the holotype, since the imprint of the gyne is strongly distorted, and ants cannot be identified by gaster alone. Therefore we cannot place this species in any known species or describe as a valid species, and suggest treating Formica obtecta as Formicidae incertae generis.

The collection of UMJG\&P contains specimen no. 77.577, labelled as a syntype of Formica obtecta. Actually, it is a gyne of Liometopum imhoffi, which cannot be considered a syntype, because it differs from the figures of both specimens from which this species was originally described.

(Formicinae) fragilis (HEER, 1849) n. comb. Fig. 15C
1867 Formica fragilis Heen, p. 8, pl. 1, figs. 4, 5a, b (\%, $\left.\mathrm{O}^{7}\right)$. Unresolved junior homonym of Formica fragilis F. Sмгтн, 1859 (= Leptomyrmex fragilis).

1867 Plagiolepis fragilis (HEer, 1867). - MAYR, p. 56.

1891 Lasius fragilis (HeER, 1867) - SCUDDER, p. 713.

1907 Plagiolepis fragilis (Heer, 1867). - Handlirsch, p. 859.

1995 Formica fragilis Heer, 1849. - Bolton, p. 195.

Studied material: Lectotype of Formica fragilis UMJG\&P no. 77.541 (designated here,, , figured by HeER, 1867: pl. 1, fig. 4b). Other specimens identified by Heer as F. fragilis: GBA no. 2009/016/0169 (\$); NHMW no. 1852.XXIX.31 (2).

Remarks: HeER (1867) described this species from 12 males and one gyne. The gyne, depicted by HeEr in pl. 1, fig. $4 \mathrm{~b}$, has been preserved (specimen UMJG\&P no. 77.541); we designate this specimen as lectotype. The compression fossil includes the wings and fragments of the gaster. In addition, we have found three other specimens indentified by Heer as F. fragilis. Specimen GBA no. 2009/016/0169 also includes only the wings and fragments of the gaster. The wing venations of this specimen and of the lectotype are slightly different, but principally similar and characteristic of Plagiolepis. However, such venation is also found in small members of other genera of Formicinae, such as Prenolepis MAYR and Nylanderia EMERY. Therefore, we cannot be completely sure that this species actually belongs to the genus Plagiolepis. In two other specimens preserved in the same piece of rock (NHMW no. 1852.XXIX.31), the wing venation has not been preserved, and the preservation quality of the fossils does not allow their identification to genus with certainty.

MAYR (1867) examined four specimens indentified by HeER and identified two of them as males of Lasius and two, without full certainty, as gynes of Plagiolepis. Based on this, Scudder (1891) transferred this species to Lasius, and HandliRsch (1907) transferred it to Plagiolepis. In our opinion, Formica fragilis HeER should be treated as Formicinae incertae generis.

(Formicidae) obvoluta HeER, 1849 n. comb. Fig. 15D

1849 Formica obvoluta HeER, p. 141, pl. 10, fig. 9f (described as $\left.0^{7}\right)$.

1867 Formica obvoluta HeER, 1849. - HeER, p. 16.

1867 Formica obvoluta HEeR, 1849. - MaYr, p. 56.

1907 Formica obvoluta HeER, 1849. - HandLIRSCh, p. 864.

1995 Formica obvoluta Heer, 1849. - Bolton, p. 200.

Studied material: Holotype UMJG\&P no. 77.646f (?worker, designated by HeER, 1849: pl. 10, fig. 9f)). Other specimen identified by HeER as $F$. obvoluta: GBA no.

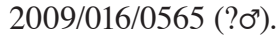




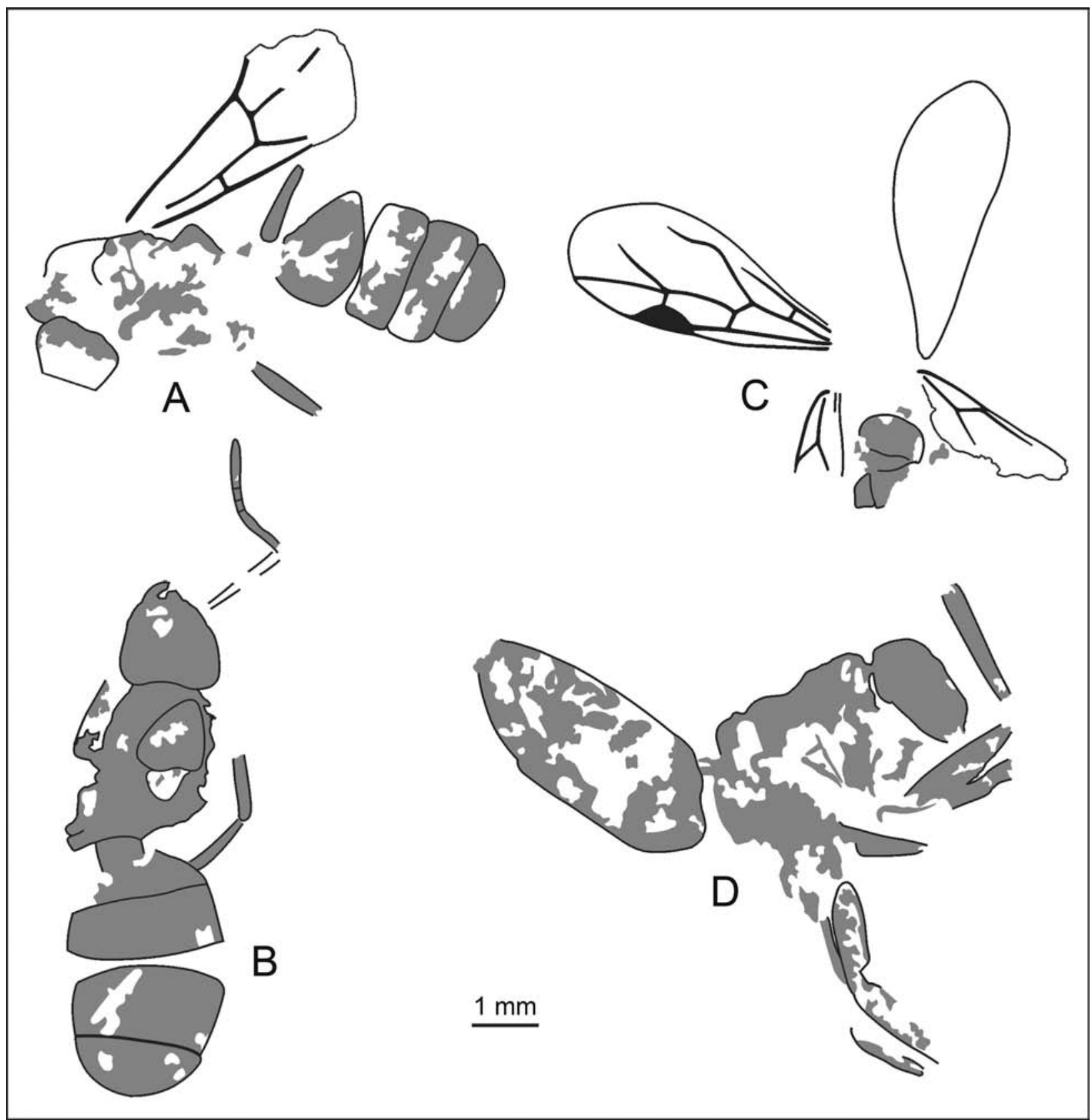

Fig. 15. Formicidae incertae generis. A - holotype of Formica oculata HeER, 1849, UMJG\&P no. 77.646d (\$); B - holotype of Formica obtecta Heer, 1849, UMJG\&P no. 77.646c (9); C - lectotype of Formica fragilis HeER, 1849, UMJG\&P no. 77.541 (\$); D - holotype of Formica obvoluta HeER, 1849, UMJG\&P no. $77.646 f$ (? worker).

Remarks: HeER described this species from a single specimen preserved in the same piece of rock as other ants. This specimen has been preserved in the UMJG\&P collection. HEER stated in his description that the gaster of this ant con- sists of six distinct segments, and therefore, considered this specimen male. Actually, the segmentation of the gaster is not visible in the compression fossil, and the shape of the mesosoma and gaster give evidence that it is most likely a 
worker. Specimen GBA no. 2009/016/0565, identified by HeER, is a very poorly-preserved male, which cannot be identified to genus. MAYR (1867) examined two specimens indentified by HEER as $F$. obvoluta, and identified one of them as a male of Formica. Based on this, HandLIRSCH (1907) left this species in the genus Formica. Judging by the one-segmented waist and absence of a constriction between the first and second gastral segments, the holotype of $F$. obvoluta belongs to Formicinae or Dolichoderinae. However, the specimen is so poorly-preserved that we cannot place it in any known species, or describe as a valid species. Therefore, we suggest treating Formica obvoluta as Formicidae incertae generis.

\section{Formicidae taxa unavailable for study Ponera croatica HeER, 1849}

1849 Ponera croatica Heen, p. 148, pl. 12, fig. 3 (\%).

1964 Poneropsis croatica (HEER, 1849). - TAYLOR, p. 138.

1995 Poneropsis croatica (Heer, 1849). - Bolton, p. 363.

HeER described this species from two specimens, which we have failed to find. We have also failed to find in the studied collections any other specimens identified as $P$. croatica. MAYR (1867) examined one specimen identified by HEER (but not one of the syntypes), and tentatively identified it as a gyne of the subfamily Ponerinae. However, the specimen figured by HeER lacks a constriction between the first and second gastral segments, and the closed cell $\mathrm{rm}$ in the forewing; therefore, there is no reason to place this species in the subfamily Ponerinae.

\section{Poneropsis pallida HeER, 1867}

1867 Poneropsis pallida Heer, p. 23, pl. 2, fig. 2 (\%).

1907 Poneropsis pallida Heer, 1867. - Handlirsch, p. 880.

1995 Poneropsis pallida Heer, 1867. - Bolton, p. 363.

HEER described this species from a single specimen, which we have failed to find. MAYR (1867) did not see this species. We have also failed to find in the studied collections any other specimens identified as $P$. pallida. Judging by the figure and description, this species may belong to the subfamily Ponerinae, but this can be determined only if the holotype is found.

\section{Poneropsis brunascens HeER, 1867}

1867 Poneropsis brunascens HeER, p. 27, pl. 2, fig. 7 (o').

1907 Poneropsis brunascens HeER, 1867. - HANDLIRSCH, p. 881.

1995 Poneropsis brunascens Heer, 1867. - Bolton, p. 363.

HeER described this species from a single specimen, which we have failed to find. MAYR (1867) did not see this species either. We have also failed to find in the studied collections any other specimens identified as $P$. brunascens. Judging by HeER's description and figure, the holotype of this species is most probably a male Liometopum, but this can be determined with certainty only if the holotype is found.

\section{Myrmica venusta HEER, 1867}

1867 Myrmica venusta HeER, p. 31, pl. 2, fig. 12 (\%). Unresolved junior primary homonym of Myrmica venusta F. Sмітн, 1858 (=Monomorium).

1867 Solenopsis venusta (HeER, 1867). - MAyr, p. 60.

1907 Solenopsis venusta (Heer, 1867). - HandliRsch, p. 873.

1995 Myrmica venusta Heer, 1867. - Bolton, p. 284.

HeER described this species from a single specimen, which, as well as any other specimens identified as M. venusta, we have failed to find in the studied collections. MAYR (1867) examined two specimens of this species identified by HEER (a gyne and a male preserved in one piece of rock) and tentatively identified them as Solenopsis. However, judging by HeER's figure, the holotype of this species cannot belong to the subfamily Myrmicinae. The waist and wing venation were not preserved, and it can be seen in the figure that the shape and segmentation of the gaster were characteristic of Formicinae or Dolichoderinae.

\section{Conclusions}

We found in collections of three museums of Austria a total of 539 compression fossils of ants from Radoboj, 307 of them with original Heer's labels. We designated the holotypes, lectotypes and neotypes for 54 of the 62 species described by HEER, and subsequently compared the other specimens to these types. As a result, we have identified 350 specimens to subfamily and 311 specimens to species. We re-described 23 species originally described by HeER $(1849,1867)$ and two species described by MAYR (1867). One genus and eight species are described as new; 27 species and varieties described by HeER are synonymized. The taxonomic placement of eight species originally described by HEER remains unclear.

As a result of our revision, the known assemblage of Radoboj includes 33 species of 15 genera and five subfamilies (Tab. 1). These results make it possible to compare this assemblage with other Cenozoic ant assemblages.

Although the ants have been described from many deposits of various ages, the data from the majority of studies cannot be used for comparison, because they contain descriptions of particular species, but no complete data on the assemblage. The ant assemblages 

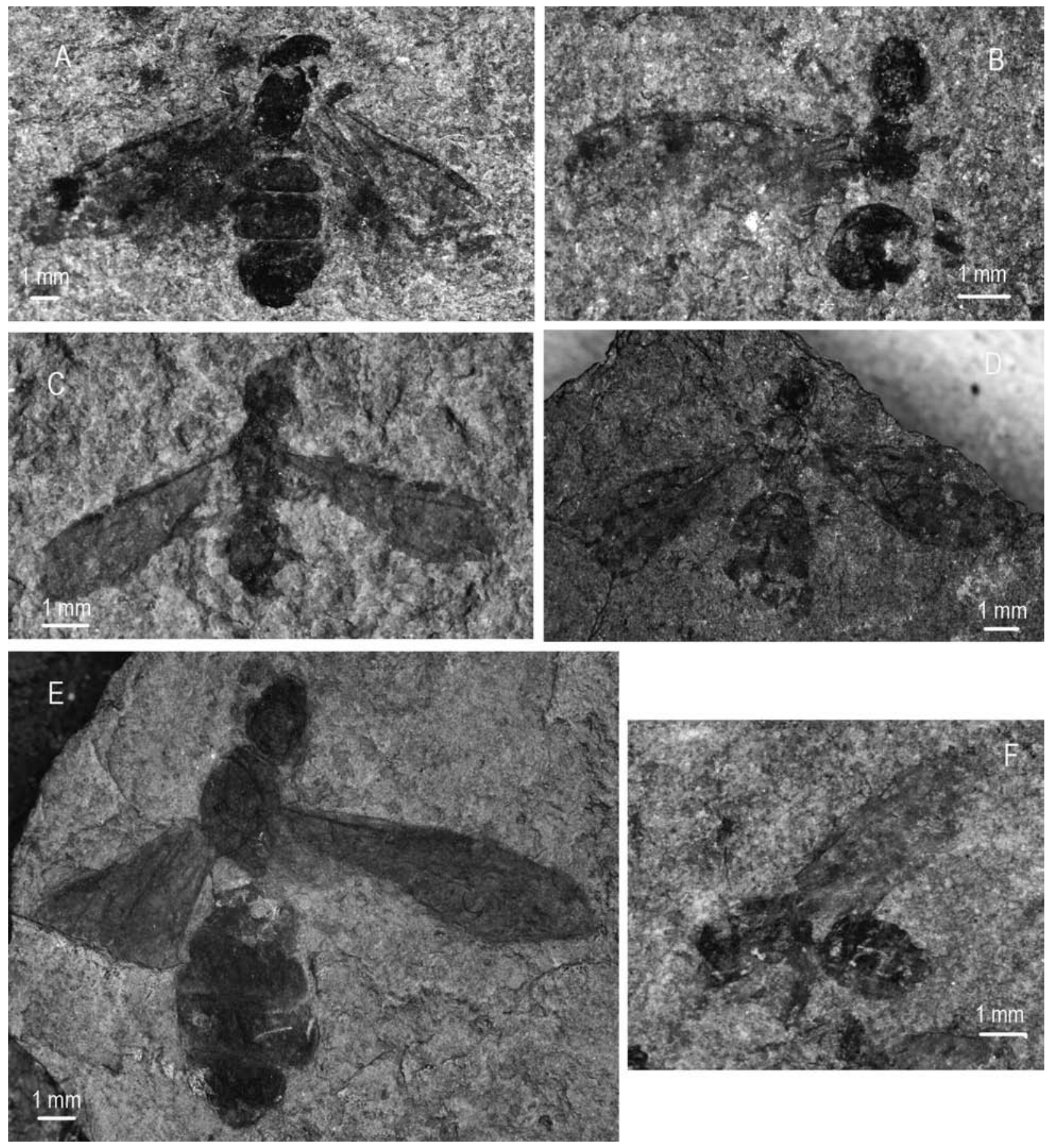

Fig. 16. Photographs of fossils of the subfamily Dolichoderinae and poneromorph subfamilies. A - Liometopum imhoffii (HeEr, 1849), holotype of Ponera affinis HeER, 1849, UMJG\&P no. 77.638 (P); B - Emplastus antiquus (MAYR, 1867), neotype GBA no. 2009/016/0459 (\%); C - Ponerites oblongiceps sp. nov., holotype GBA no. 2009/016/0515 (P); D - Emplastus dubius sp. nov., holotype UMJG\&P no. 77.527 (\$); $\mathbf{E}$ - Emplastus miocenicus sp. nov., holotype NHMW no. 1852.XXIX.32 (९); F - Dolichoderus heeri sp. nov., holotype UMJG\&P no. 77.507a (\$).

Fig. 17. Photographs of fossils of the subfamily Formicinae. A - Attopsis longipennis HeER, 1849, lectotype UMJG\&P no. 210962 (P); B - L. anthracinus (HEER, 1867), neotype of Poneropsis anthracinus HeER, 1867, GBA no. 2009/016/0074 (P); C - Heeridris croaticus sp. nov., holotype NHMW no. 1852.I.999 (9); D - Camponotus induratus (HeER, 1849), specimen NHMW no. 1852.XXIX.4 determined by HeER as Formica indurata, studied by MAYR (\%); E - Gesomyrmex bremii (HEER, 1849), lectotype of Myrmica bremii HEER, 1849, UMJG\&P no. 77.482 (\%); F - Formica parexsecta sp. nov., holotype GBA no. 2009/016/0355 (P). 

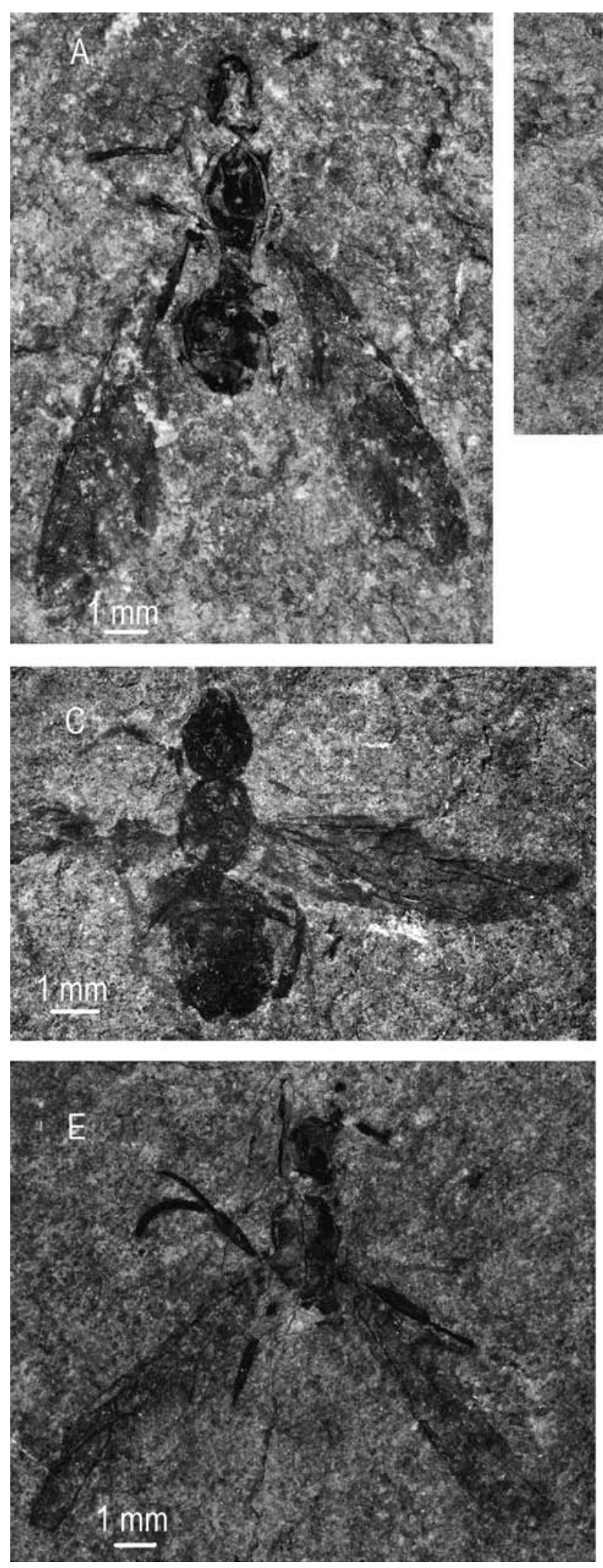

Fig. 17.
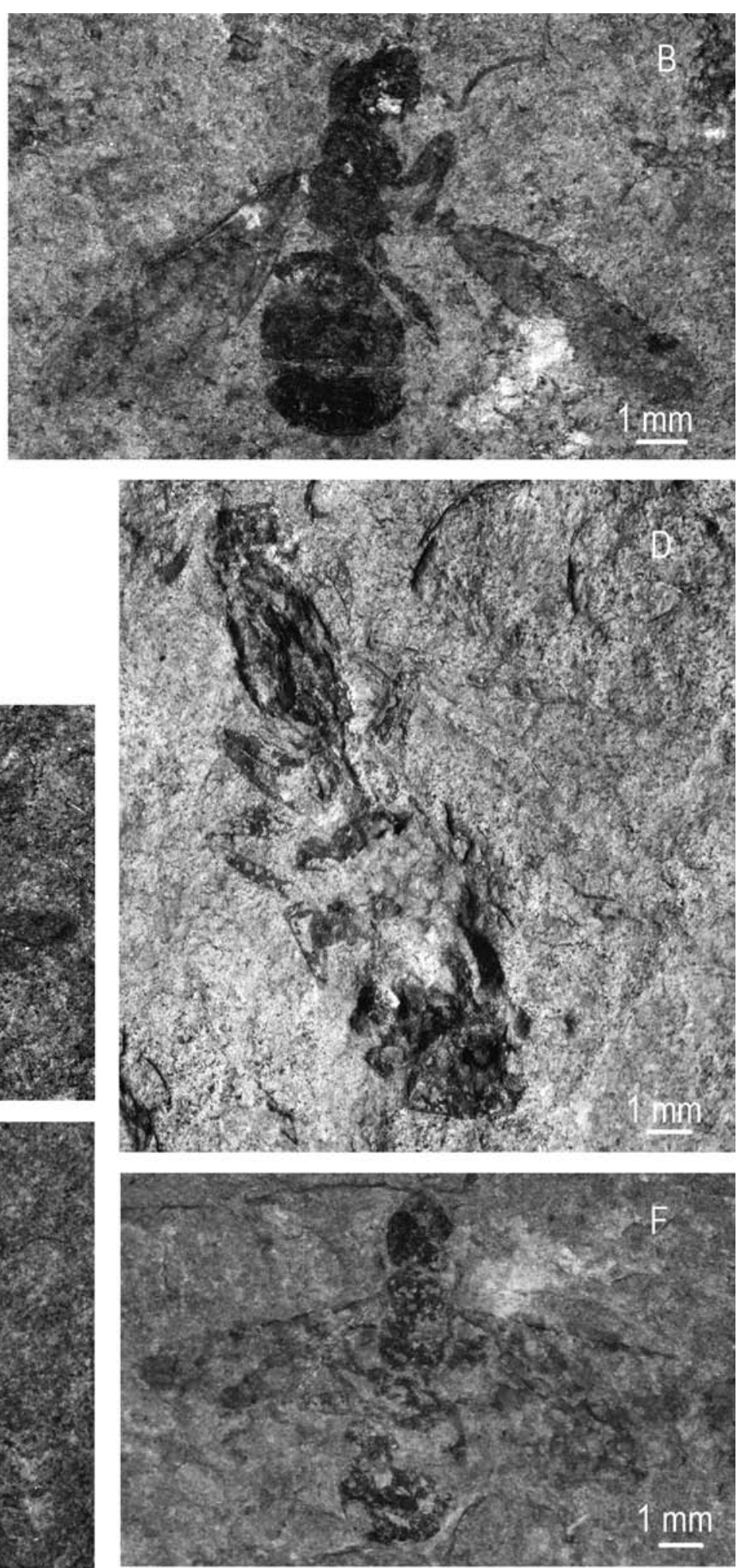

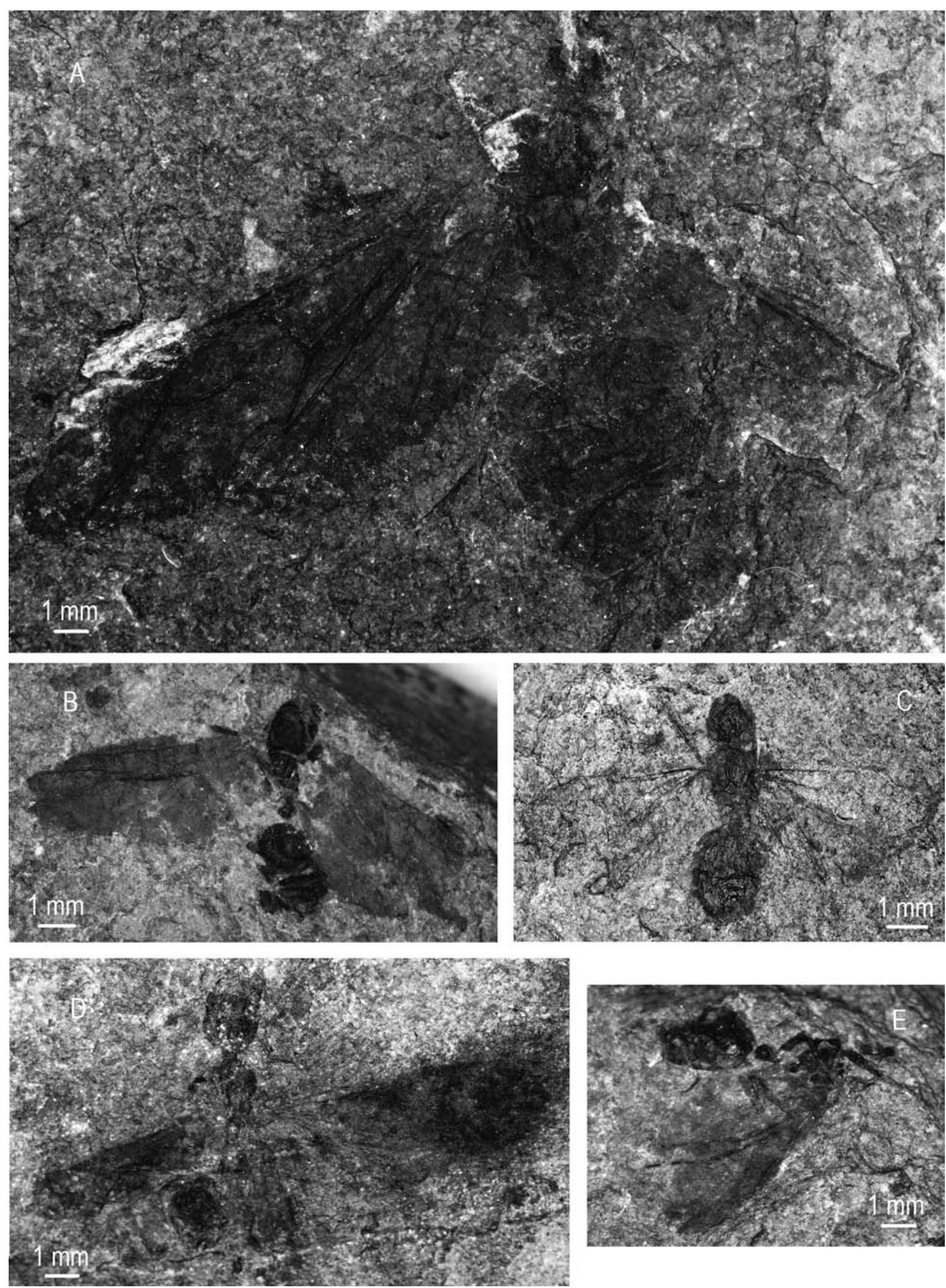

Fig. 18. 
Table 1. Composition and proportions of ant species in Radoboj.

\begin{tabular}{|c|c|c|}
\hline Species & Number & $\begin{array}{c}\text { Proportion } \\
{[\%]}\end{array}$ \\
\hline \multicolumn{3}{|l|}{ AMBLYOPONINAE } \\
\hline *Casaleia longiventris (HEER) & 1 & 0.3 \\
\hline \multicolumn{3}{|l|}{ DOLICHODERINAE } \\
\hline Dolichoderus heeri n. sp. & 5 & 1.6 \\
\hline *Emplastus antiquus (MAYR) & 1 & 0.3 \\
\hline *Emplastus dubius n. sp. & 1 & 0.3 \\
\hline *Emplastus haueri (MAYR) & 1 & 0.3 \\
\hline *Emplastus miocenicus n. sp. & 2 & 0.6 \\
\hline *Emplastus? ocellus (HEER) & 4 & 1.3 \\
\hline Liometopum imhoffii (HEER) & 22 & 7.1 \\
\hline \multicolumn{3}{|l|}{ FORMICINAE } \\
\hline Attopsis longipennis HEER & 1 & 0.3 \\
\hline Camponotus induratus (HEER) & 10 & 3.2 \\
\hline Formica obscura HeER & 4 & 1.3 \\
\hline Formica parexsecta $\mathrm{n}$. sp. & 1 & 0.3 \\
\hline Formica ungeri HEER & 60 & 19.3 \\
\hline Gesomyrmex bremii (HEER) & 1 & 0.3 \\
\hline Heeridris croaticus n. sp. & 2 & 0.6 \\
\hline Lasius anthracinus (HEER) & 24 & 7.7 \\
\hline Lasius globularis (HEER) & 13 & 4.2 \\
\hline Lasius longaevus (HEER) & 33 & 10.6 \\
\hline Lasius longipennis (HEER) & 14 & 4.5 \\
\hline Lasius occultatus (HEER) & 46 & 14.8 \\
\hline Lasius ophthalmicus (HEER) & 25 & 8.0 \\
\hline Oecophylla obesa (HEER) & 23 & 7.4 \\
\hline \multicolumn{3}{|l|}{ MYRMICINAE } \\
\hline Lonchomyrmex freyeri (HEER) & + & + \\
\hline *Myrmecites pusillus (HEER) & 1 & 0.3 \\
\hline *Myrmecites latus n. sp. & 2 & 0.6 \\
\hline *Paraphaenogaster jurinei (HEER) & 2 & 0.6 \\
\hline *Paraphaenogaster tertiaria (HEER) & 2 & 0.6 \\
\hline \multicolumn{3}{|l|}{ PONERINAE } \\
\hline *Ponerites atavinus (HEER) & 1 & 0.3 \\
\hline *Ponerites elongatus (HEER) & 1 & 0.3 \\
\hline *Ponerites gracilior $\mathrm{n} . \mathrm{sp}$. & 1 & 0.3 \\
\hline *Ponerites nitidus (HEER) & 1 & 0.3 \\
\hline *Ponerites oblongiceps n. sp. & 3 & 1.0 \\
\hline *Ponerites tenuis (HEER) & 3 & 1.0 \\
\hline TOTAL & 311 & \\
\hline
\end{tabular}

* species of form genera described to date (at a modern level) are those of the following fossil sites: Green River Formation, USA, Eocene, Middle Ypresian to Earliest Lutetian, 53.548.5 Ma (Dlussky \& Rasnitsyn, 2003); European Baltic, Bitterfeldian, Rovno and Scandinavian ambers, Late Eocene, Priabonian, ca. $37 \mathrm{Ma}$ (review: Dlussky \& RASNITSYN 2009); Bembridge, Isle of Wight, UK, Late Eocene, Priabonian, ca. 35 Ma (Dlussky \& PerFILIEVA 2014); Florissant, Colorado, USA, Eocene/Oligocene boundary, ca.34 Ma (CARPENTER 1930); Stavropol, southern Russia, Middle Miocene, Burdigalian, ca. 16.0-20.4 Ma (Dlussky 1981). The rich deposits of the Middle Eocene of Germany from Grube Messel (ca. $47 \mathrm{Ma}$ ) and Eckfeld Maar (ca. $44 \mathrm{Ma}$ ) have been described only in part (LuTZ 1986; DLuSSKY et al. 2008, 2009; Dlussky \& Wedmann 2012). The assemblages described earlier from Oeningen, Austria, Late Miocene (HeEr 1849, 1867), Aix-en-Provence, France, Oligocene (ThÉOBALD 1937) and Fushun amber, China, Middle Eocene (Hong 2002) require complete revision and cannot be used for comparison at this time.

As shown by earlier studies (DLUSSKY \& RASNITSYN 2009), the most adequate results for the comparison of assemblages are the results on the frequency spectra of the subfamilies. Data on the proportions of members of different ant subfamilies in different fossil sites are given in Table 2. We used for comparison Shorygin's index (Shorygin 1939), also known as Schoener's overlap index (SCHOENER 1974). It is calculated as the sum of the minimum values of relative abundance across all the species represented in both compared habitats, expressed in percents:

$\mathrm{PS}=\Sigma \min \left|\mathrm{P}_{\mathrm{ki}}, \mathrm{P}_{\mathrm{kj}}\right|$,

where $P_{k i}$ is the proportion of the subfamily $k$ in the total number of specimens in the sample $i, P_{k j}$ is its proportion in the sample $\mathrm{j}$, and $\min \left|\mathrm{P}_{\mathrm{ki}}, \mathrm{P}_{\mathrm{kj}}\right|$ is the minimum of the two values $P$.

The assemblage of Radoboj is especially similar at the subfamily level to the assemblage of Bembridge $(P S=0.95)$. In both Radoboj and Bembridge, Formicinae are dominant (over 80\%), the proportion of Dolichoderinae is considerably smaller $(9.4 \%$ and $13.8 \%$, respectively), and the proportion of Myrmicinae is at most $2 \%$. Strong similarity between these assemblages

Fig. 18. Photographs of fossils of the subfamily Myrmicinae and Oecophylla obesa (HeER, 1849). A, B, E - Oecophylla obesa (HeER, 1849). A - lectotype of Formica obesa radobojana UMJG\&P no. 77.625 (P); B - neotype of Attopsis anthracina HeEr, 1849, GBA no. 2009/016/0634 (o'); E - lectotype of Attopsis longipes HeER, 1867, UMJG\&P no. 77.561 (o'); C - Myrmecites latus, sp. nov., holotype NHMW no. 2014/0130/0001 (\$); D - Paraphaenogaster tertiaria (HeER, 1849), holotype of Myrmica bicolor HEER, 1867, UMJG\&P no. 77.624 (P). 
Table 2. Proportions of members of different subfamilies of ants in fossil assemblages.

\begin{tabular}{l|c|c|c|c|c|c|c|c}
\hline \multirow{2}{*}{ Subfamily } & \multicolumn{9}{|c|}{ Europa } & \multicolumn{2}{c}{ N. America } \\
\cline { 2 - 9 } & $\begin{array}{c}\text { Baltic } \\
\text { amber }\end{array}$ & $\begin{array}{c}\text { Bitterfeld } \\
\text { amber }\end{array}$ & $\begin{array}{c}\text { Rovno } \\
\text { amber }\end{array}$ & Bembridge & Radoboj & Stavropol & Green River & Florissant \\
\hline Amblyoponinae & 0.0 & 0.0 & 0.0 & 0.0 & 0.3 & 0.0 & 0.0 & 0.0 \\
\hline Aneuretinae & 0.3 & 0.1 & 0.0 & 0.2 & 0.0 & 0.0 & 2.9 & 0.0 \\
\hline Cerapachyinae & 0.1 & 0.3 & 0.2 & 0.0 & 0.0 & 0.0 & 0.0 & 0.0 \\
\hline Dolichoderinae & 63.4 & 53.9 & 52.7 & 13.8 & 9.4 & 3.9 & 71.6 & 62.6 \\
\hline Ectatomminae & 0.0 & 0.4 & 0.2 & 0.0 & 0.0 & 0.0 & 0.0 & 0.0 \\
\hline Formicinae & 33.1 & 37.0 & 39.5 & 81.3 & 84.9 & 52.6 & 2.9 & 32.5 \\
\hline Myrmeciinae & 0.1 & 0.1 & 0.0 & 0.0 & 0.0 & 0.0 & 10.8 & 0.0 \\
\hline Myrmicinae & 2.0 & 5.9 & 4.7 & 0.5 & 2.0 & 40.8 & 2.0 & 4.8 \\
\hline Ponerinae & 0.6 & 0.4 & 1.0 & 4.3 & 3.4 & 2.6 & 9.8 & 0.0 \\
\hline Proceratinae & 0.1 & 0.3 & 0.3 & 0.0 & 0.0 & 0.0 & 0.0 & 0.0 \\
\hline Pseudomyrmecinae & 0.3 & 1.5 & 1.5 & 0.0 & 0.0 & 0.0 & 0.0 & 0.0 \\
\hline $\begin{array}{l}\text { Number of specimens } \\
\text { examined }\end{array}$ & 11579 & 679 & 1155 & 630 & 350 & 76 & 102 & 5592 \\
\hline
\end{tabular}

is also found at the generic level. At both sites, members of the genera Camponotus, Dolichoderus and Oecophylla, and form genera Paraphaenogaster and Ponerites have been recorded, and the majority of ants from Bembridge included in the morphogenus Leucotaphus most probably belong to the genus Lasius. The principal difference between these assemblages at the generic level is that in Bembridge members of the genus Oecophylla are markedly dominant (over 60\%, in contrast to $7.4 \%$ in Radoboj), and members of the genus Formica are absent, while in Radoboj they make up $21.4 \%$ of all ant fossils.

The similarity is rather high $(\mathrm{PS}=0.61)$ between the assemblages of Radoboj and Stavropol. At both sites, members of Formicinae are dominant (84.9 and $52.6 \%$, respectively), and members of Dolichoderinae are rare $(9.4 \%$ and $3.9 \%$, respectively). However, imprints of Myrmicinae make up about $40.8 \%$ in Stavropol, in contrast to only $2 \%$ in Radoboj. The two assemblages are similar also at the generic level: at both sites fossils of the genera Camponotus, Lasius, Liometopum, and form genera Paraphaenogaster and Ponerites have been recorded.

The structure of the assemblages of the Late Eocene ambers of Europe considerably differs from those of Bembridge, Radoboj and Stavropol. In these ambers, members of the subfamily Dolichoderinae are dominant (52.7-63.4\%), and the proportion of Formicinae is only $33.1-39.5 \%$, determining the relatively low similarity between the assemblages of these ambers and the assemblage of Radoboj (PS $=0.45-0.52$ ). At the same time, these assemblages show signs of continuity. The majority of the genera found in Radoboj are also present in the Late Eocene ambers. It should also be noted that the proportion of extinct genera in the ambers ( 25 of the 56 recorded genera, or $45 \%$ ) is markedly higher than in Radoboj, where four of the 15 recorded genera are doubtlessly extinct.

The difference of the assemblage of Radoboj from those of the Middle Eocene deposits of Messel and Eckfeld is even greater. Almost half of the ant fossils known from these deposits are giant members of the genus Titanomyrma Archibald, Johnson, Mathewe \& GrEENwOOD, 2011, which belongs to the extinct subfamily Formiciinae. Messel is also characterized by a greater diversity and relatively high abundance of poneromorph subfamilies (Amblyoponinae, Ectatomminae and Ponerinae). But, in this case, continuity between the assemblages at the generic level is also clear. Fossil ants found both in the Middle Eocene deposits of Europe and in Radoboj include members of the genera Casaleia, Oecophylla and Gesomyrmex, never recorded in deposits from North America. The similarity of the fossil assemblage of Radoboj with fossil assemblages of North America at the subfamily level is also rather low: $\mathrm{PS}=0.44$ with Florissant and $\mathrm{PS}=$ 0.18 with Green River.

Finally, another peculiar feature of the assemblage of Radoboj should be noted, making it similar to the assemblages of the Late Eocene ambers of Europe and 
the assemblage of Bembridge: the simultaneous presence of Palaearctic and tropical elements. In Radoboj, members of the genera Formica and Lasius are dominant. In the Recent fauna, members of these genera live only in the Palaearctic and Nearctic. At the same time, extant species of the genera Oecophylla and Gesomyrmex occur exclusively in the tropics. Fossil members of the genus Oecophylla were found earlier in Messel, Eckfeld, the Baltic and Bitterfeld ambers, Bembridge, and various Oligocene and Miocene deposits of the Old World (DuussKy et al. 2008). Extinct members of Gesomyrmex were known earlier from Messel, Eckfeld and the Baltic, Bitterfeld and Rovno ambers (Dlussky et al. 2009). Extant members of Oecophylla do not survive subzero temperatures; therefore, the records of fossil members of the genus give evidence of a warm climate.

\section{Acknowledgements}

We are grateful to Mag. Dr. Martin Gross (Universalmuseum Joanneum), Mag. Dr. Irene Zorn (Geologische Bundesanstalt), Priv.-Doz. Mag. Dr. Mathias Harzhauser and Mag. Thomas Nichterl (Naturhistorisches Museum Wien) for to the chance to study materials and for their help in examining the specimens.. We are indebted to the editor (Dr. Guenter Schweigert) and reviewers (Francisco RiQuelme (Mexico) and two anonymous reviewers) of this manuscript for their constructive comments and suggestions which surely improved the final result. We also thank Dr. PETR Petrov for the help with the translation of the article. This study was supported by the Russian Foundation for Basic Research, project no. 11-04-00421.

\section{References}

Archibald, S.B., Johnson, K.R., Mathewes, R.W. \& GreenwOOD, D.R. (2011): Intercontinental dispersal of giant thermophilic ants across the Arctic during early Eocene hyperthermals. - Proceedings of the Royal Society, (B), 278: $3679-3686$.

Bingham, C.T. (1903): The fauna of British India, including Ceylon and Burma. Hymenoptera, Vol. II. Ants and Cuckoo-wasps. - 506 pp.; London (Taylor \& Francis).

Bolton, B. (1994): Identification Guide to the Ant Genera of the World. - 222 pp.; Cambridge (Harvard University Press).

Bolton, B. (1995): A New General Catalogue of the Ants of the World. - 504 pp; Cambridge (Harvard University Press).

Bolton, B. (2003): Synopsis and classification of Formicidae. - Memoirs of the American Entomological Institute, 71: 1-370.

Carpenter, F.M. (1930): The fossil ants of North America. - Bulletins of the Museum of Comparative Zoollogy, 70: 1-66.
Cockerell, T.D.A. (1915): British fossil insects. - Proceedings of the United States National Museum, 49: 469499.

Cockerell, T.D.A. (1920): Fossil arthropods in the British Museum. 1. - Annals and Magazine of Natural History, Ser. 9, 5: 273-279.

CuRTIS, J. (1839): Formica rufa. The red, hill, or horse Ant, or Pismire. Plate 752 [plus 2 unnumbered pages of text]. - In: CurTis, J. (Ed.): British entomology; being illustrations and descriptions of the genera of insects found in Great Britain and Ireland, 16: 722-769; London (published by the author).

Dalla Torre, K.W. v. (1893): Catalogus Hymenopterorum hucusque descriptorum systematicus et synonymicus. Vol. 7. Formicidae (Heterogyna). - 289 pp.; Leipzig (Engelmann).

DLussky, G.M. (1981): Miocene ants (Hymenoptera, Formicidae) of the USSR. - Trudy Paleontologicheskogo Instituta Akademii Nauk SSSR, 183: 64-83.

Dlussky, G.M. (2002): Ants of the genus Dolichoderus Lund (Hymenoptera: Formicidae) from the Baltic and Rovno ambers. - Paleontological Journal, 36 (1): 50-63.

Dlussky, G.M. (2008a): Ants of the Tribe Formicini (Hymenoptera, Formicidae) from Late Eocene amber of Europe. - Paleontological Journal, 42 (5): 500-513.

DLussky, G.M. (2008b): New species of ants of the genus Dolichoderus (Hymenoptera, Formicidae) from Late Eocene ambers of Europe. - Vestnik Zoologii, 42 (6): 497-514.

Dlussky, G.M. (2009): The ant subfamilies Ponerinae, Cerapachyinae, and Pseudomyrmecinae (Hymenoptera, Formicidae) in the Late Eocene ambers of Europe. Paleontological Journal, 43 (9): 1043-1086.

DLussky, G.M. (2011): The ants of the genus Lasius FABRICIUS (Hymenoptera, Formicidae) from the Late Eocene European ambers. - Vestnik Zoologii, 45 (3): 209-222.

Dlussky, G.M. \& Perefilieva, K.S. (2014): The ants, family Formicidae Latreille, 1802. - In: Antropov, A.V., Belokobyldki, S.A., Compton S.G., Dlussky, G.M., KhAlaim, A.I., Kolyada, M.A., Kozlov, M.A., Perfilieva, K.S. \& Rasnitsyn, A.P. (Eds.): The wasps, bees and ants (Insecta: Vespida=Hymenoptera) from the insect limestone (Late Eocene) of the Isle of Wight, UK. Edinburg (in press.).

Dlussky, G.M. \& Rasnitsyn, A.P. (2002): Ants (Hymenoptera: Formicidae) of Formation Green River and some other Middle Eocene deposits of North America. - Russian Entomological Journal, 11 (4): 411-436.

Dlussky, G.M. \& Rasnitsyn, A.P. (2009): Ants (Insecta: Vespida: Formicidae) in the Upper Eocene amber of central and eastern Europe. - Paleontological Journal, 43 (9): 1024-1042.

Dlussky, G.M., Wappler, T. \& Wedmann, S. (2008): New Middle Eocene formicid species from Germany and the evolution of weaver ants. - Acta Palaeontoljgica Polonica, 53 (4): 615-626.

Dlussky, G.M., Wappler, T. \& Wedmann, S. (2009): Fossil ants of the genus Gesomyrmex MAYR (Hymenoptera, Formicidae) from the Eocene of Europe and remarks on the evolution of arboreal ant communities. - Zootaxa, 2031: $1-20$. 
Dlussky, G.M. \& Wedmann, S. (2012): The poneromorph ants (Hymenoptera, Formicidae: Amblyoponinae, Ectatomminae, Ponerinae) of Grube Messel, Germany: high biodiversity in the Eocene. - Journal of Systematic Palaeontology, 10 (4): 725-753.

DoNisTHORPE, H. (1920): British Oligocene ants. - Annals and Magazine of Natural History, Series 9, 6: 81-94.

ERICHSON, W.F. (1842): Beitrag zur Insecten-Fauna von Vandiemensland, mit besonderer Berücksichtigung der geographischen Verbreitung der Insecten. - Archiv für Naturgeschichte, 8 (1): 83-287.

FABRICIUS, J.C. (1775): Systema entomologiae, sistens insectorum classes, ordines, genera, species adiectis synonymis, locis, descriptionibus, observationibus. - 832 pp.; Flensburgi et Lipsiae (Korte).

FABRICIUS, J.C. (1804): Systema Piezatorum secundum ordines, genera, species, adjectis synonymis, locis, observationibus, descriptionibus. - XIV + $15+439+30$ pp.; Brunswick (C. Reichard).

Forel, A. (1878): Études myrmécologiques en 1878 (première partie) avec l'anatomie du gésier des fourmis. - Bulletins de la Société Vaudoise des Sciences Naturelles, 15: 337-392.

Forel, A. (1893): Sur la classification de la famille des Formicides, avec remarques synonymiques. - Annales de la Société Entomologique de Belgique, 37: 161-167.

Germar, E.F. (1837): Fauna insectorum Europae. Fasciculus 19. Insectorum protogaeae specimen sistens insecta carbonum fossilium. - pls. 1-25; Halle (Kümmel).

Handlirsch, A. (1907): Die fossilen Insekten und die Phylogenie der rezenten Formen. Lieferung 6. - p. 801-960; Leipzig (Engelmann).

HeER, O. (1847): Die Insektenfauna der Tertiärgebilde von Oeningen und von Radoboj in Croatien. Vol. I. Käfer. 222 pp.; Leipzig (Engelmann).

HeER, O. (1849): Die Insektenfauna der Tertiärgebilde von Oeningen und von Radoboj in Croatien. Vol. 2. Heuschrecken, Florfliegen, Alderflügen, Schmetterlinge, und Fliegen. - 264 pp.; Leipzig (Engelmann).

HeER, O. (1853): Die Insektenfauna der Tertiärgebilde von Oeningen und von Radoboj in Croatien. Vol. 3. Rhynchoten. - 138 pp.; Leipzig (Engelmann).

Heer, O. (1864): Die Urwelt der Schweiz. [Lieferungen 7-11.], 289-469; Zürich (Schulthess).

Heer, O. (1867): Fossile Hymenopteren aus Oeningen und Radoboj. - Neue Denkschriften der allgemeinen Schweizerischen Gesellschaft für die gesammten Naturwissenschaften, 22: 1-42.

Hong, Y.-C. (1984 [1983]): Fossil insects in the diatoms of Shanwang. - Bulletin Tianjin Institute Geological Mineral Resources, 8: 1-12 [in Chinese].

Hong, Y.C. (2002): Amber insects of China. - 631 pp.; Beijing (Beijing Scientific and Technological Publishing House/Henan Scientific and Technological Publishing House) [in Chinese].

LAtreille, P.A. (1802): Histoire naturelle générale et particulière des Crustacés et des insectes. Tome 3. Familles naturelles des genres. - XII + 467 pp.; Paris (Dufart).

LAtreille, P.A. (1809): Genera crustaceorum et insectorum secundum ordinem naturalem in familias disposita, iconibus exemplisque plurimus explicata. Tomus 4. - 399 pp.; Paris \& Strasbourg (Koenig).

Lepeletier de Saint-Fargeau, A. (1835 [1836]): Histoire naturelle des insectes. Hyménoptères. Tome I. - 547 pp.; Paris (Roret).

LinNAEUS, C. (1758): Systema naturae per regna tria naturae, secundum classes, ordines, genera, species, cum characteribus, differentiis, synonymis, locis. Tomus I. Editio decima, reformata. - 824 pp.; Holmiae (Laurentii Salvii).

LinnAeus, C. (1771): Mantissa plantarum altera generum editionis VI \& specierum editionis II. - [6] + $143+587$ pp.; Holmiae (Laurentii Salvii).

Lund, P.W. (1831): Lettre sur les habitudes de quelques fourmis du Brésil, adressée à M. Audouin. - Annales des Sciences Naturelles, 23: 113-138.

LuTz, H. (1986): Eine neue Unterfamilie der Formicidae (Insecta: Hymenoptera) aus dem mittel-eozänen Ölschiefer der "Grube Messel" bei Darmstadt (Deutschland, SHessen). - Senckenbergiana lethaea, 67: 177-218.

Lutz, H. (1997): Taphozönosen terrestrischer Insekten in aquatischen Sedimenten - ein Beitrag zur Rekonstruktion des Paläoenvironments. - Neues Jahrbuch für Geologie und Paläontologie, Abhandlungen, 203 (2): 173210.

Mayr, G. (1855): Formicina austriaca. Beschreibung der bisher im österreichischen Kaiserstaate aufgefundenen Ameisen, nebst Hinzufügung jener in Deutschland, in der Schweiz und in Italien vorkommenden Arten. Verhandlungen des Zoologisch-Botanischen Vereins in Wien, 5: 273-478.

MaYr, G. (1861): Die europäischen Formiciden. Nach der analytischen Methode bearbeitet. - 80 pp.; Wien (C. Gerolds Sohn).

Mayr, G. (1867): Vorläufige Studien über die RadobojFormiciden, in der Sammlung der k. k. geologischen Reichsanstalt. - Jahrbuch der kaiserlich-königlichen Geologischen Reichsanstalt, Wien, 17: 47-62.

MaYr, G. (1868): Die Ameisen des baltischen Bernsteins. Beiträge zur Naturkunde Preussens, 1: 1-102.

Meunier, F. (1915): Über einige fossile Insekten aus den Braunkohlenschichten (Aquitanien) von Rott (Siebengebirge). - Zeitschrift der Deutschen Geologischen Gesellschaft, 67: 205-217.

Meunier, F. (1917): Sur quelques insectes de l'Aquitainien de Rott, Sept Montagnes (Prusse rhénane). - Verhandelingen der Koninklijke Akademie van Wetenschappen te Amsterdam. Tweede Sectie, 20: 3-17.

Meunier, F. (1923): Sur quelques nouveaux insectes des lignites oligocènes (Aquitanien) de Rott, Siebengebirge (Rhénanie). - Verhandlungen der Koninklijke Akademie van Wetenschappen te Amsterdam, 26: 605-612.

NovÁk, O. (1877): Fauna der Cyprisschiefer des Egerer Tertiärbeckens. - Sitzungsberichte der Koeniglichen Akademie der Wissenschaften, MathematischNaturwissenschaftliche Classe, 76: 71-96.

PAGLIANO, G. \& SCARAMOZZINO, P. (1990 [1989]): Elenco dei generi di Hymenoptera del mundo. - Memorie della Societa Entomologica Italiana, 68: 1-210.

PANZER, G.W.F. (1798): Fauna insectorum germanicae initia, oder Deutschlands Insecten. Heft 54. - 24 pp., 24 pls.; Nürnberg (Felssecker). 
Popov, V. (1933): Two new fossil ants from Caucasus (Hymenoptera, Formicidae). - Trudy Paleozoologicheskogo Instituta Akadademii Nauk SSSR, 2: 17-21.

Rasnitsyn, A.P. \& Zherikhin, V.V. (2002): Alphabetic list of selected insect fossil sites. 4.1. Impression fossils. In: Rasnitsyn, A.P. \& Quicke, D.L.J. (Eds.): History of insects, 437-444; Dordrecht (Kluwer).

Roger, J. (1861): Die Ponera-artigen Ameisen (Schluss). Berliner Entomologische Zeitschrift, 5: 1-54.

ScudDER, S.H. (1891): Index to the known fossil insects of the world, including myriapods and arachnids. - Bulletins of the United States Geological Survey, 71: 1-744.

ShatTUCK, S.O. (1992): Review of the dolichoderine ant genus Iridomyrmex MAYR with descriptions of three new genera (Hymenoptera: Formicidae). - Journal of Australian Entomological Society, 31: 13-18.

ShATTUCK, S.O. (1994): Taxonomic catalog of the ant subfamilies Aneuretinae and Dolichoderinae (Hymenoptera: Formicidae). - University of California Publications in Entomology, 112: I-XIX, 1-241.

Shorygin, A.A. (1939): Feeding, selectiveabilities, and food relationships of some Gobiidae in the Caspian Sea. Zoologicheskij Zhurnal, 18: 27-51.

Smith, F. (1853 [1854]): Monograph of the genus Cryptocerus, belonging to the group Cryptoceridae - family Myrmicidae - division Hymenoptera Heterogyna. - The Transactions of the Entomological Society of London, 2: $213-228$.

Smith, F. (1857): Catalogue of the hymenopterous insects collected at Sarawak, Borneo; Mount Ophir, Malacca; and at Singapore, by A. R. Wallace [part]. - Journal of the Proceedings of the Linnean Society of London, Zoology, 2: 42-88.

Smith, F. (1858): Catalogue of hymenopterous insects in the collection of the British Museum. Part VI. Formicidae. - 216 pp.; London (British Museum).

Smith, F. (1859): Catalogue of hymenopterous insects collected by Mr. A. R. Wallace at the islands of Aru and Key [part]. - Journal of the Proceedings of the Linnean Society of London, Zoology, 3: 132-158.

Smith, F. (1860): Catalogue of hymenopterous insects collected by Mr. A. R. Wallace in the islands of Bachian, Kaisaa, Amboyna, Gilolo, and at Dory in New Guinea. - Journal of the Proceedings of the Linnean Society of London, Zoology, 5 (17b), suppl. to vol. 4: 93-143.
Schoener, T.W. (1974): Resource partitioning in ecological communities. - Science, 185 (4145): 29-39.

TAYLOR, R.W. (1964): Taxonomy and parataxonomy of some fossil ants (Hymenoptera-Formicidae). - Psyche, 71: 134-141.

Théobald, N. (1937): Les insectes fossiles des terrains oligocènes de France. - Mémoires de la Société des Sciences de Nancy, nouvelle série, 1: 1-473.

WHEELER, W.M. (1911): A list of the type species of the genera and subgenera of Formicidae. - Annals of the New York Academy of Sciences, 21: 157- 77.

WhEELER, W.M. (1915 [1914]): The ants of the Baltic Amber. - Schriften der Physikalisch-ökonomischen Gesellschaft zu Königsberg in Preußen, 55: 1-142.

ZHANG, J. (1989): Fossil insects from Shanwang, Shandong, China. Jinan, China. - 459 pp.; Shandong (Science and Technology Publishing House).

Zhang, J., Sun, B. \& Zhang, X. (1994): Miocene insects and spiders from Shanwang, Shandong. - V + 298 pp.; Shandong (Beijing Science Press).

Manuscript received: December 11th, 2013.

Revised version accepted by the Stuttgart editor: March 30th, 2014.

\section{Addresses of the authors:}

Gennady M. Dlussky, Department of Evolution, Biological Faculty, M.V. Lomonosov Moscow State University, Vorobjevy gory, 119992 Moscow, Russia;

e-mail:dlusskye@mail.ru

Tatyana S. Putyatina, Department of Evolutionary Biology, Biological Faculty, Lomonosov Moscow State Universtiy, Vorobjevy gory 1/12, Moscow 119991, Russia; e-mail: tsergput@gmail.com 